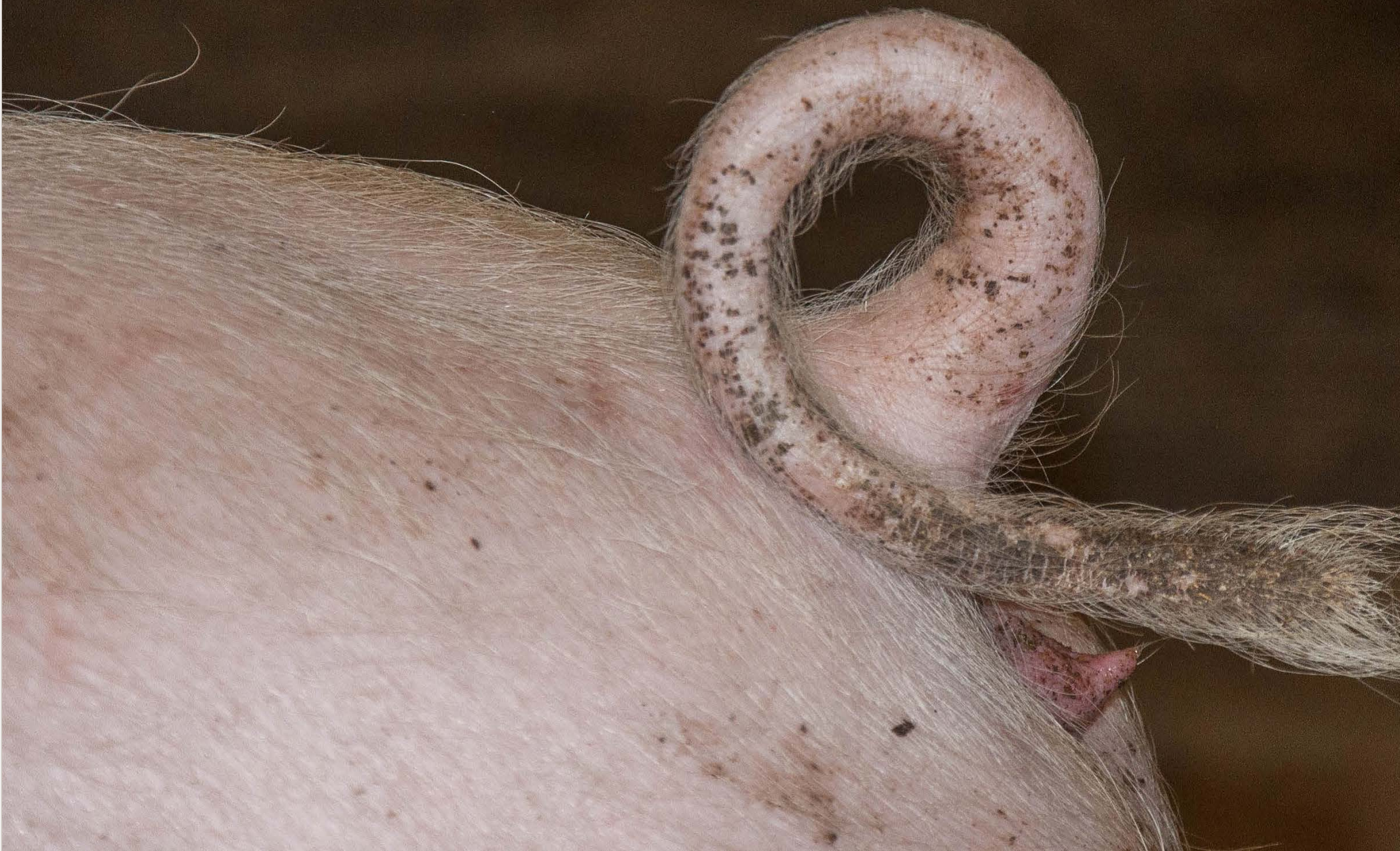

\title{
Effect van voersamenstelling op bijtgedrag bij varkens
}

Carola van der Peet-Schwering, Nienke Dirx, Marion Kluivers-Poodt, Gisabeth Binnendijk, Liesbeth Bolhuis, Geert van der Peet 



\title{
Effect van voersamenstelling op bijtgedrag bij varkens
}

Carola van der Peet-Schwering ${ }^{1}$, Nienke Dirx ${ }^{2}$, Marion Kluivers-Poodt ${ }^{1}$, Gisabeth Binnendijk ${ }^{1}$, Liesbeth Bolhuis ${ }^{3}$, Geert van der Peet ${ }^{1}$

\author{
${ }^{1}$ Wageningen Livestock Research \\ ${ }^{2}$ Wageningen Livestock Research, VIC Sterksel \\ ${ }^{3}$ Wageningen Universiteit, leerstoelgroep Adaptatiefysiologie
}

Dit onderzoek is uitgevoerd als onderdeel van de publiek-private samenwerking (PPS) "Samenwerkende Varkenshouderijketen" met financiering vanuit de topsector Agri\&Food.

Wageningen Livestock Research

Wageningen, Januari 2017

Rapport 1008 
Carola van der Peet-Schwering, Nienke Dirx, Marion Kluivers-Poodt, Gisabeth Binnendijk, Liesbeth Bolhuis, Geert van der Peet, 2017. Effect van voersamenstelling op bijtgedrag bij varkens.

Wageningen Livestock Research, Livestock Research Rapport 1008.

Samenvatting NL: Op Varkens Innovatie Centrum Sterksel is onderzocht of bijtgedrag (staart-, oor- en flankbijten) en staart- en oorschade bij dieren met intacte (niet gecoupeerde) staarten verminderd kunnen worden door de dieren vanaf enkele dagen na geboorte tot afleveren naar het slachthuis voer met extra vezels (verzadigend voer) en/of voer met extra aminozuren (tryptofaan, threonine en methionine) te geven. De resultaten van het onderzoek zijn beschreven in dit rapport.

Dit rapport is gratis te downloaden op http://dx.doi.org/10.18174/402570 of op www.wur.nl/livestock-research (onder Wageningen Livestock Research publicaties).

\section{(C) 2017 Wageningen Livestock Research}

Postbus 338, 6700 AH Wageningen, T 03174839 53, E info.livestockresearch@wur.nl, www.wur.nl/livestock-research. Wageningen Livestock Research is onderdeel van Wageningen University \& Research.

Wageningen Livestock Research aanvaardt geen aansprakelijkheid voor eventuele schade voortvloeiend uit het gebruik van de resultaten van dit onderzoek of de toepassing van de adviezen.

Alle rechten voorbehouden. Niets uit deze uitgave mag worden vermenigvuldigd en/of openbaar gemaakt worden door middel van druk, fotokopie, microfilm of op welke wijze dan ook zonder voorafgaande toestemming van de uitgever of auteur. onderzoeksopdrachten zijn de Algemene Voorwaarden van de Animal Sciences Group van toepassing. Deze zijn gedeponeerd bij de Arrondissementsrechtbank Zwolle. 


\section{Inhoud}

Woord vooraf $\quad 5$

Samenvatting $\quad 7$

$1 \quad$ Inleiding $\quad 11$

2 Materiaal en methode $\quad 13$

$\begin{array}{llr}2.1 & \text { Proeflocatie en proefdieren } & 13\end{array}$

$\begin{array}{lll}2.2 & \text { Proefbehandelingen } & 13\end{array}$

$\begin{array}{lll}2.3 & \text { Proefopzet en proefindeling } & 13\end{array}$

$\begin{array}{lll}2.4 & \text { Voeding en drinkwaterverstrekking } & 14\end{array}$

$\begin{array}{lll}2.5 & \text { Huisvesting en klimaat } & 15\end{array}$

$\begin{array}{lll}2.6 & \text { Hokverrijking } & 16\end{array}$

$\begin{array}{lll}2.7 & \text { Afleverstrategie } & 17\end{array}$

$\begin{array}{lll}2.8 & \text { Plan van aanpak bij staart-, oor- of flankschade } & 17\end{array}$

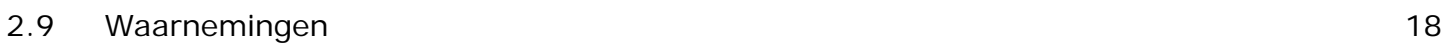

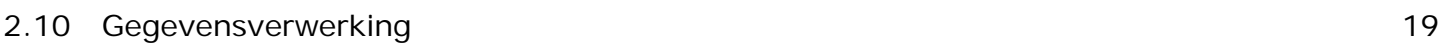

2.10.1 Statistische analyse van de technische resultaten $\quad 19$

2.10.2 Staart-, oor- en flankbeschadigingen en gedragswaarnemingen 20

$\begin{array}{ll}2.10 .3 \text { Hok- en dierkaarten } & 20\end{array}$

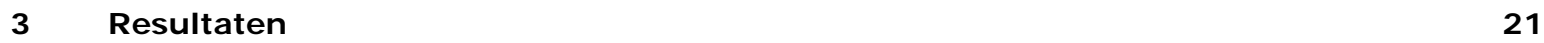

$\begin{array}{lll}3.1 & \text { Technische resultaten } & 21\end{array}$

$\begin{array}{lll}3.1 .1 & \text { Zoogperiode } & 21\end{array}$

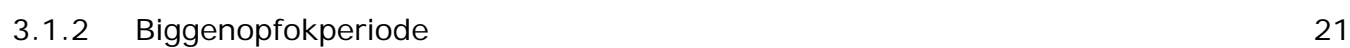

3.1.3 Vleesvarkensfase 23

3.2 Veterinaire behandelingen en uitval 25

3.2.1 Zoogperiode $\quad 25$

$\begin{array}{lll}3.2 .2 & \text { Biggenopfokperiode } & 25\end{array}$

$\begin{array}{lll}3.2 .3 & \text { Vleesvarkensfase } & 26\end{array}$

$\begin{array}{lll}3.3 & \text { Staart-, oor en flankbeschadigingen } & 27\end{array}$

$\begin{array}{lll}3.4 & \text { Gedragswaarnemingen } & 30\end{array}$

$\begin{array}{lll}3.4 .1 & \text { Biggenopfokperiode } & 30\end{array}$

$\begin{array}{lll}3.4 .2 & \text { Vleesvarkensfase } & 30\end{array}$

3.5 Vangnet en verbruik hokverrijkingsmateriaal 31

$\begin{array}{lll}3.6 & \text { Financiële resultaten } & 34\end{array}$

4 Discussie $\quad 37$

$\begin{array}{lll}4.1 & \text { Bijtgedrag en bijtschade } & 37\end{array}$

$\begin{array}{lll}4.2 & \text { Technische resultaten } & 40\end{array}$

5 Conclusies $r$

$\begin{array}{ll}\text { Literatuur } & 43\end{array}$ 
Bijlage 1

Samenstelling biggenvoer

Bijlage 2

Samenstelling vleesvarkensvoer

47

Bijlage 3

Oranje hokkaart

50

Bijlage 4

Rode hokkaart

51

Bijlage 5

Dierkaart

52

Bijlage 6

Technische resultaten kraamstal

53

Bijlage 7

Technische resultaten gespeende biggen

54

Bijlage 8

Technische resultaten vleesvarkens

55

Bijlage 9

Slachtkwaliteit vleesvarkens

56

Bijlage 10

Uitval biggen en vleesvarkens

57

Bijlage 11

Staart-, oor- en flankbeschadigingen

59

Bijlage 12

Gedragswaarnemingen

61 


\section{Woord vooraf}

Een varken wordt geboren met een staart. Deze wordt in de gangbare varkenshouderij binnen 4 dagen gecoupeerd. Volgens Richtlijn 2008/120/EG (de Europese Richtlijn tot vaststelling van minimumnormen ter bescherming van varkens) en het Besluit diergeneeskundigen, is het routinematig couperen van varkensstaarten niet toegestaan: '... het verwijderen van een deel van de staart [is toegestaan] bij biggen tot de leeftijd van vier dagen, mits getroffen maatregelen, waaronder het aanpassen van omgevingsfactoren of beheerssystemen, waarbij de omgeving en de varkensdichtheid in aanmerking worden genomen en die dienen ter voorkoming van staartbijten en andere gedragsstoornissen, niet werkzaam zijn gebleken'. Het couperen van staarten tast de integriteit van het dier aan.

De werkgroep krulstaart heeft dan ook het routeplan "varkens houden met een krul" opgesteld. In de werkgroep hadden zitting: de Vakgroep Varkenshouderij van Land- en Tuinbouw Organisatie Nederland (LTO), de Nederlandse Vakbond Varkenshouders (NVV), de Nederlandse Vereniging tot Bescherming van Dieren, Coppens diervoeding, Topigs Norsvin, de Koninklijke Nederlandse Maatschappij voor Diergeneeskunde, Vion Food Group, het Departement Dierwetenschappen en Livestock Research van Wageningen UR, en het Ministerie van Economische Zaken. In een zevental lezingen door experts zijn de belangrijkste factoren die bijdragen aan het ontstaan van bijtproblemen behandeld. In de bijeenkomsten zijn de onderwerpen fokkerij, economie, voeding, gezondheid, afleiding en klimaat de revue gepasseerd. In de lezingen is nog eens benadrukt dat staartbijten een multifactorieel probleem is, optredend in zowel de reguliere houderij (bij gecoupeerde staarten) als de biologische houderij (bij intacte staarten), waarbij de oorzaak van bedrijf tot bedrijf kan verschillen. Hoewel veel wetenschappelijke kennis beschikbaar is, ontbreekt het aan praktische handvatten om in de praktijk succesvol over te gaan naar volledig stoppen met couperen of naar het stapsgewijs minder kort te couperen. Dit heeft juni 2013 geresulteerd in de Verklaring van Dalfsen waarin de ketenpartijen gezamenlijk de ambitie uitspreken om te onderzoeken of het mogelijk is om op een verantwoorde manier stapsgewijs minder kort te couperen en uiteindelijk geheel te stoppen met couperen in de bestaande stallen.

Staartbijten is een Europees probleem. Het is daarom goed te constateren dat er een nauwe samenwerking is ontstaan tussen Duitsland, Denemarken en Nederland. Het belang van internationale afstemming bestaat vooral ook in verband met de handel van varkens en de toekomstige marktvraag naar dieren met een juist wel of niet gecoupeerde staart.

Om de doelstelling van de Verklaring van Dalfsen te realiseren is een routeplan opgesteld dat startte met een demonstratieproject op VIC Sterksel, het ontwikkelen van een vangnet waarmee staartbijtproblemen zorgvuldig gestopt kunnen worden en een netwerk van varkenshouders om in de praktijk met de problematiek aan de slag te gaan. De resultaten van het demonstratieproject zijn in maart 2016 gepubliceerd.

Eén van de risicofactoren ten aanzien van staartbijten is voeding. Dit rapport laat de resultaten zien van een onderzoek naar het effect van voersamenstelling op het bijtgedrag van varkens.

Tot slot wil ik de stuurgroep en begeleidingscommissie bedanken voor hun rol bij de uitvoering van het onderzoek. De stuurgroep bestaande uit LTO, NVV, Dierenbescherming en Ministerie van EZ; de begeleidingscommissie bestaande uit de vertegenwoordigers van de Werkgroep krulstaart. Daarnaast bedank ik de dierverzorgers en Rik Verheijen van VIC Sterksel voor de goede uitvoering van de proef en Jan Wijnen en Fleur Bartels van Wageningen Universiteit voor het mee helpen uitvoeren van de gedragswaarnemingen.

Geert van der Peet,

Projectleider 


\section{Samenvatting}

Op Varkens Innovatie Centrum Sterksel is onderzocht of bijtgedrag (staart-, oor- en flankbijten) en bijtschade (staart- en oorschade) bij dieren met een intacte (niet gecoupeerde) staart verminderd kunnen worden door de dieren vanaf enkele dagen na geboorte tot afleveren naar het slachthuis voer met extra vezels (verzadigend voer) en/of extra aminozuren (tryptofaan, threonine en methionine) te geven. Daarnaast is nagegaan wat het effect van deze voeders is op de technische en financiële resultaten van gespeende biggen en vleesvarkens. Het onderzoek is uitgevoerd in de periode oktober 2015 tot en met juni 2016 met in totaal 59 lacterende zeugen en hun biggen, 576 gespeende biggen ( 48 hokken x 12 dieren) en 576 vleesvarkens (48 hokken x 12 dieren) van het kruisingstype Tempo beer $x$ Topigs zeug. In het onderzoek zijn vanaf een paar dagen na geboorte tot afleveren naar het slachthuis vier proefbehandelingen met elkaar vergeleken in een $2 \times 2$ factoriële proef. De twee factoren waren:

1) geen versus wel extra vezels in het voer; een deel van de tarwe in de controlevoeders was vervangen door 12 tot $14 \%$ vezelrijke grondstoffen zoals haverschillen, bietenpulp, cichorei, sojahullen en zonnepitschroot.

2) geen versus wel extra aminozuren in het voer; de voeders met extra aminozuren bevatten $20 \%$ meer darmverteerbaar methionine en threonine en $30 \%$ meer darmverteerbaar tryptofaan door de toevoeging van synthetische aminozuren aan de controlevoeders.

Bij spenen op een leeftijd van vier weken zijn de biggen uit 2 à 3 tomen binnen dezelfde proefbehandeling gemengd en werden in alle hokken zes beren en zes zeugjes opgelegd. Na spenen kregen de biggen dezelfde proefbehandeling als voor spenen. Vijf weken na spenen zijn de biggen als hok overgeplaatst naar de vleesvarkensstal. De gespeende biggen en vleesvarkens werden onbeperkt gevoerd via 2-vaksdroogvoerbakken. De biggen kregen de eerste 14 dagen speenvoer en zijn daarna abrupt overgeschakeld op opfokvoer. De vleesvarkens kregen vijf weken startvoer, vier weken tussenvoer en daarna eindvoer.

In de kraamstal kregen de biggen als hokverrijking een jute doek. De gespeende biggen en vleesvarkens kregen als hokverrijking: jute doek (gespeende biggen) of jute zak (vleesvarkens), lange ketting met 3 bouten hangend tot op de vloer en een ketting met een houten blokje (gespeende biggen) of boomstammetje (vleesvarkens).

Tweemaal daags werden vanaf de voergang de staarten, oren en flanken van alle dieren (zowel de zuigende biggen, de gespeende biggen als de vleesvarkens) gecontroleerd. Bij zichtbaar bijtgedrag of bijtschade(dieren beten elkaar en/of er waren verse bijtpuntjes c.q. verwondingen met vers bloed zichtbaar) werd een vangnet (maatregelen om staartbijten te verminderen/stoppen) ingezet om het bijten zo snel mogelijk te stoppen. Dit vangnet bestond uit het ophangen van twee verticale touwen in het hok en het twee maal daags verstrekken van een halve schep luzerne in een rond bakje (gespeende biggen) of het verstrekken van luzerne in een mand die boven de dichte vloer werd opgehangen (vleesvarkens).

Op een leeftijd van 4 weken (bij spenen), 9 weken (bij opleg in de vleesvarkensstal), 14 weken (bij de overgang van startvoer naar tussenvoer), 18 weken (bij de overgang van tussenvoer naar eindvoer) en daags voor afleveren zijn alle individuele dieren beoordeeld op staart-, oor- en flankbeschadigingen en op intacte staartlengte. Daarnaast zijn op 7 en 21 weken leeftijd live gedragswaarnemingen bij de dieren verricht. 
Bijtgedrag en staart- en oorschade:

- Staartbijten kwam al in de kraamstal voor. Bij spenen op 4 weken leeftijd had $64 \%$ van de dieren geen staartbeschadiging, $24 \%$ had bijtsporen en $12 \%$ had een zichtbare wond.

- $\quad$ Op 14 en 18 weken leeftijd was het percentage dieren zonder staartbeschadigingen lager dan de dag voor afleveren (respectievelijk 61, 58 en $81 \%$ op 14 en 18 weken leeftijd en de dag voor afleveren) en het percentage dieren met een zichtbare wond hoger (respectievelijk 21 , 29 en $18 \%$ op 14 en 18 weken leeftijd en de dag voor afleveren). Aan het eind van de vleesvarkens periode zijn de staartbeschadigingen mogelijk deels hersteld door inzet van het vangnet.

- $\quad$ Bij afleveren had $81 \%$ van de vleesvarkens geen staartbeschadiging, $1 \%$ had bijtsporen en $18 \%$ had een zichtbare wond.

- Het percentage dieren met een intacte staartlengte (er mist geen deel van de staart) daalde van $98 \%$ op 4 weken leeftijd naar $77 \%$ daags voor afleveren.

- Oorbeschadigingen kwamen het meeste voor bij de gespeende biggen (17\% van de biggen op 9 weken leeftijd) en in veel mindere mate bij de vleesvarkens ( $3 \%$ van de vleesvarkens daags voor afleveren).

- Het verstrekken van extra vezels of van extra aminozuren in het voer heeft bij biggen in de kraamstal en bij gespeende biggen niet geresulteerd in minder bijtgedrag en minder staarten oorschade.

- $\quad$ Bij de vleesvarkens resulteerde het verstrekken van extra vezels via het voer in minder staartschade (hoger percentage dieren zonder staartbeschadiging; hoger percentage dieren met een intacte staartlengte; lager percentage dieren met een zichtbare staartwond; minder dieren naar noodopvang vanwege aangebeten staart (respectievelijk 3,3 en 0,4\% van de vleesvarkens bij geen en wel extra vezels in het voer).

- Het verstrekken van extra aminozuren in het voer verhoogde het percentage vleesvarkens zonder staartbeschadigingen bij afleveren (respectievelijk 75,2 en 85,5\% bij geen en wel extra aminozuren in het voer). Het percentage vleesvarkens met een intacte staartlengte was echter lager bij extra aminozuren in het voer (respectievelijk 80,6 en 73,1\% bij geen en wel extra aminozuren in het voer).

Inzet vangnet:

- In de biggenopfokstal is in 11 van de 48 hokken een vangnet (touw en luzerne) ingezet gedurende 2 tot 19 dagen. Bij 85\% van de biggen was de staart- of oorwond na een week hersteld en kon gestopt worden met het inzetten van het vangnet.

- $\quad$ Eén hok (met vezelrijk voer) met ingezet vangnet vanwege staartbijten is ca. 3,5 weken na spenen uit het onderzoek genomen vanwege ernstig vechten van de dieren. Er waren enkele dieren in het hok, die continue het gevecht aangingen met de andere dieren in het hok, waardoor een deel van de dieren wonden aan de nek hadden. Het is niet duidelijk waarom deze dieren steeds het gevecht aangingen.

- $\quad$ Bij de vleesvarkens is in 27 van de 47 hokken een vangnet (touw en luzerne) ingezet gedurende 1 tot 5 weken. De meeste vleesvarkens hadden drie dagen na inzet van het vangnet een korst op de staartwond

Technische en financiële resultaten:

- $\quad$ Er waren geen verschillen in voeropname, groei en voederconversie tussen gespeende biggen die wel of geen extra vezels in het voer kregen.

- De vleesvarkens die extra vezels in het voer kregen namen minder voer op, groeiden langzamer, hadden dunner spek en hadden een hoger vleespercentage dan de vleesvarkens die geen extra vezels in het voer kregen.

- De gespeende biggen die extra aminozuren in het voer kregen namen de eerste twee weken na spenen minder voer op, groeiden langzamer en hadden een ongunstigere voederconversie dan de biggen die geen extra aminozuren in het voer kregen. Van dag 14 tot dag 35 na spenen en tijdens de vleesvarkensperiode waren er geen verschillen in voeropname, groei en voederconversie tussen de dieren die wel of geen extra aminozuren in het voer kregen. 
- Het financiële resultaat per afgeleverde big was hoger bij de biggen die het controlevoer kregen dan bij de biggen die het controlevoer met extra aminozuren kregen. Het financiële resultaat per afgeleverde big van de biggen die het vezelrijke voer of het vezelrijke voer met extra aminozuren kregen zat hier tussen in.

- Het saldo per afgeleverd vleesvarken was het hoogst was bij de vleesvarkens die het controlevoer kregen a.g.v. een hogere opbrengst en lagere voerkosten per afgeleverd vleesvarken. Het saldo per afgeleverd vleesvarkens verschilde niet tussen de vleesvarkens die het vezelrijke voer, het voer met extra aminozuren of het vezelrijke voer met extra aminozuren kregen.

Samenvattend kan geconcludeerd worden dat met name het verstrekken van extra vezels in het voer resulteerde in een hoger percentage vleesvarkens zonder staartschade (het percentage dieren met een intacte staartlengte bij afleveren naar het slachthuis was respectievelijk 71 en $82 \%$ bij geen en wel extra vezels in het voer). Echter, ook bij extra vezels in het voer kwam staartschade voor. Staartbijten is een multifactorieel probleem en kon in dit onderzoek niet volledig voorkomen worden door alleen extra vezels of een combinatie van extra vezels en extra aminozuren toe te voegen aan het voer. Een vangnet was nodig om bijtgedrag zo snel mogelijk te stoppen. 


\section{$1 \quad$ Inleiding}

Een varken wordt geboren met een staart. Deze wordt in de gangbare varkenshouderij binnen 4 dagen gecoupeerd. Volgens Richtlijn 2008/120/EG (de Europese Richtlijn tot vaststelling van minimumnormen ter bescherming van varkens) en het Besluit diergeneeskundigen, is het routinematig couperen van varkensstaarten niet toegestaan: '... het verwijderen van een deel van de staart [is toegestaan] bij biggen tot de leeftijd van vier dagen, mits getroffen maatregelen, waaronder het aanpassen van omgevingsfactoren of beheerssystemen, waarbij de omgeving en de varkensdichtheid in aanmerking worden genomen en die dienen ter voorkoming van staartbijten en andere gedragsstoornissen, niet werkzaam zijn gebleken'.

Het couperen van staarten is pijnlijk en tast de integriteit van het dier aan (integriteit verwijst naar de heelheid en gaafheid van een dier). Ook de varkenssector zelf wil het liefst een ingreepvrije varkenshouderij. De reden dat varkensstaarten in de reguliere varkenshouderij veelal gecoupeerd worden is dat de kans groot is dat varkens (op latere leeftijd) aan elkaars staart gaan bijten. Dit bijten kan leiden tot grote gezondheids- en welzijnsproblemen bij de varkens en tot grote economische schade voor de varkenshouders. Couperen is echter een vorm van symptoombestrijding die het onderliggende probleem niet aanpakt en zelfs niet in alle gevallen afdoende is om staartbijten te voorkomen. Om varkens met intacte staarten te houden, zullen aanpassingen en extra inspanningen gedaan moeten worden. Ook bij varkens in de biologische houderij en die gehouden worden op stro komt bijtgedrag voor. Om op een verantwoorde manier te stoppen met couperen, is een verantwoorde, onderbouwde aanpak onontbeerlijk.

De werkgroep krulstaart heeft in 2013 het routeplan "Varkens houden met een krul" opgesteld. In de werkgroep hadden zitting: de Vakgroep Varkenshouderij van Land- en Tuinbouw Organisatie Nederland (LTO), de Nederlandse Vakbond Varkenshouders (NVV), de Nederlandse Vereniging tot Bescherming van Dieren, Coppens diervoeding, Topigs Norsvin, de Koninklijke Nederlandse Maatschappij voor Diergeneeskunde, Vion Food Group, het Departement Dierwetenschappen en Livestock Research van Wageningen UR, en het Ministerie van Economische Zaken. In een zevental lezingen door experts zijn de belangrijkste factoren die bijdragen aan het ontstaan van bijtproblemen behandeld. In de bijeenkomsten zijn de onderwerpen fokkerij, economie, voeding, gezondheid, afleiding en klimaat de revue gepasseerd. In de lezingen is nog eens benadrukt dat staartbijten een multifactorieel probleem is, waarbij de oorzaak van bedrijf tot bedrijf kan verschillen. Hoewel veel wetenschappelijke kennis beschikbaar is, ontbreekt het aan praktische handvatten om succesvol over te gaan naar volledig stoppen met couperen of naar het stapsgewijs minder kort te couperen. Dit heeft geresulteerd in de Verklaring van Dalfsen waar de ketenpartijen gezamenlijk de ambitie aangeven om stapsgewijs minder kort te couperen bij varkens in de reguliere houderij en uiteindelijk geheel te stoppen met couperen. Om deze doelstelling te realiseren is een routeplan opgesteld dat gestart is met: 1) een demonstratieproject op VIC Sterksel met regulier gehouden varkens, 2) het ontwikkelen van een vangnet waarmee staartbijtproblemen zo snel mogelijk gestopt kunnen worden en 3) het starten van een netwerk om in de praktijk met de problematiek aan de slag te gaan. Naast deze onderdelen wordt nadrukkelijk invulling gegeven aan een zorgvuldige communicatie en internationale samenwerking.

De resultaten van het demonstratieproject zijn in maart 2016 gepubliceerd. Het demonstratieproject heeft veel inzicht opgeleverd over het houden van varkens met intacte staarten. Ondanks de verworven inzichten traden ook aan het eind van het demonstratieproject nog steeds bijtproblemen op. Vroege signalen werden niet altijd herkend, waren misschien niet altijd zichtbaar of traden mogelijk zelfs helemaal niet op. 
Eén van de factoren die bij kan dragen aan het ontstaan van bijtproblemen is voeding. Met name beperkt voeren en een niet verzadigd gevoel vormen een risico (Mcl ntyre and Edwards, 2002). Onbeperkt voeren (Taylor et al., 2010) en meer vezels in het voer (Bolhuis et al., 2010) verminderen het risico op bijtgedrag. Meer vezels zorgen voor verlenging van de vreettijd en meer verzadiging, resulterend in minder manipulatief gedrag gericht op hokgenoten (Bolhuis et al., 2010). Vezels zorgen daarnaast voor een betere darmontwikkeling en darmgezondheid bij biggen en voor minder maagschade (minder maagzweren) (Elbers et al., 1995; Elbers en Dirkzwager, 1994).

Maagdarmproblemen zijn een risicofactor voor staartbijten (Amory et al., 2006) evenals een niet optimale gezondheid van de dieren of een tekort aan nutriënten in het voer. Uit recent onderzoek bij vleesvarkens (Van der Meer et al., 2016) is gebleken dat bijtgedrag minder voorkomt als vleesvarkens een voer krijgen dat aangevuld is met aminozuren die een rol spelen in het immuunsysteem. Dit betreft onder andere de aminozuren threonine (aanwezig in darmslijm; de behoefte is verhoogd bij darmschade), tryptofaan (aanwezig in acute fase eiwitten; de behoefte is verhoogd bij activatie van het immuunsysteem) en methionine. Daarnaast is uit diverse onderzoeken gebleken dat een hoger tryptofaangehalte in het voer leidt tot minder activiteit (Mcl ntyre and Edwards, 2002), minder vechten (Li et al., 2006) en minder staart- en oorbijten (Martinez-Trejo et al., 2009).

Op Varkens Innovatie Centrum Sterksel is onderzocht of bijtgedrag (staart-, oor- en flankbijten) en bijtschade (staart- en oorschade) bij dieren met een intacte (niet gecoupeerde) staart verminderd kunnen worden door de dieren vanaf enkele dagen na geboorte tot afleveren naar het slachthuis voer met extra vezels (verzadigend voer) en/of voer met extra aminozuren (tryptofaan, threonine en methionine) te geven. 


\section{Materiaal en methode}

\subsection{Proeflocatie en proefdieren}

Het onderzoek is uitgevoerd op Varkens Innovatie Centrum Sterksel (VIC) Sterksel in de periode oktober 2015 tot en met juni 2016 met in totaal 59 lacterende zeugen en hun biggen, 576 gespeende biggen (48 hokken x 12 dieren) en 576 vleesvarkens (48 hokken x 12 dieren) van het kruisingstype Tempo beer $x$ Topigs 20 zeug. Het onderzoek is uitgevoerd in twee ronden met een tussentijd van zes weken. Bij in totaal 59 tomen zijn de staarten van de biggen niet gecoupeerd. De mannelijke biggen zijn niet gecastreerd. De biggen zijn gevolgd vanaf geboorte tot afleveren naar het slachthuis.

\subsection{Proefbehandelingen}

In het onderzoek zijn vanaf een paar dagen na geboorte tot afleveren naar het slachthuis vier proefbehandelingen met elkaar vergeleken in een $2 \times 2$ factoriële proef. De twee factoren waren:

1) geen versus wel extra vezels in het voer;

2) geen versus wel extra aminozuren in het voer.

Dit resulteerde in de volgende vier proefbehandelingen:

1) Controlevoer: geen extra vezels en geen extra aminozuren;

2) Vezelrijk voer: een deel van de tarwe in de controlevoeders was vervangen door 12 tot $14 \%$ vezelrijke grondstoffen zoals haverschillen, bietenpulp, cichorei, sojahullen en zonnepitschroot. De voeders bevatten geen extra aminozuren.

3) Voer met extra aminozuren: deze voeders bevatten $20 \%$ meer darmverteerbaar methionine en threonine en $30 \%$ meer darmverteerbaar tryptofaan door de toevoeging van synthetische aminozuren aan de controlevoeders. Deze voeders bevatten geen extra vezels.

4) Vezelrijk voer met extra aminozuren: een deel van de tarwe in de controlevoeders was vervangen door 12 tot $14 \%$ vezelrijke grondstoffen zoals haverschillen, bietenpulp, cichorei, sojahullen en zonnepitschroot. Daarnaast bevatten deze voeders $20 \%$ meer darmverteerbaar methionine en threonine en $30 \%$ meer darmverteerbaar tryptofaan door de toevoeging van synthetische aminozuren aan het vezelrijke voer.

Het contrast in voersamenstelling is bij zowel de zuigende biggen, de gespeende biggen als de vleesvarkens gerealiseerd.

\subsection{Proefopzet en proefindeling}

\section{Kraamstal}

Circa een week voor werpen zijn de zeugen ingedeeld voor het onderzoek. Bij het verdelen van de zeugen over de vier proefbehandelingen is gebruik gemaakt van een blokkenindeling, waarbij de vier zeugen binnen een blok (één zeug per proefbehandeling) dezelfde pariteit en dezelfde verwachte werpdatum hadden. De zeugen zijn verplaatst naar één van de vier kraamafdelingen, waarbij de vier zeugen binnen een blok ad random waren toegewezen aan een hok binnen dezelfde kraamafdeling. In ronde 1 en 2 zijn in totaal respectievelijk 19 en 40 zeugen opgelegd voor het onderzoek. De tomen zijn binnen 24 tot 48 uur na geboorte van de biggen zoveel mogelijk gestandaardiseerd op 13 of 14 biggen.

\section{Biggenopfokstal}

Op een leeftijd van circa 4 weken zijn de biggen gespeend en verplaatst naar biggenopfokafdelingen. De biggen kregen na spenen dezelfde proefbehandeling als voor spenen. Daags voor spenen zijn de biggen gewogen en ingedeeld. Hierbij zijn biggen uit 2 à 3 tomen binnen een proefbehandeling 
gemengd (minimaal drie biggen uit dezelfde toom), waarbij er naar gestreefd is dat alle hokken een vergelijkbaar gemiddeld speengewicht met een vergelijkbare spreiding hadden en in alle hokken 6 beren en 6 zeugjes lagen. Biggen met zichtbare afwijkingen bij spenen of biggen die ziek waren zijn niet opgelegd in de proef. Alle biggenopfokafdelingen hadden acht hokken. In ronde 1 zijn twee biggenopfokafdelingen opgelegd (totaal 16 hokken) en in ronde 2 vier afdelingen (totaal 32 hokken). In elke afdeling werden twee hokken van elke proefbehandeling opgelegd.

Vleesvarkensstal

Vijf weken na spenen (op een leeftijd van circa 9 weken) zijn de dieren als hok overgeplaatst naar de vleesvarkensstal. Alle vleesvarkensafdelingen hadden 12 hokken voor 12 dieren. Bij minder dan 12 dieren (door uitval in de opfokperiode) zijn geen dieren bijgeplaatst in een hok. In ronde 1 zijn de vleesvarkens opgelegd in twee vleesvarkensafdelingen. In beide afdelingen zijn acht hokken ( 2 hokken per proefbehandeling) opgelegd. In ronde 2 zijn de vleesvarkens opgelegd in drie vleesvarkensafdelingen. In twee afdelingen werden 12 hokken opgelegd ( 3 hokken per proefbehandeling) en in één afdeling acht hokken ( 2 hokken per proefbehandeling). De overige vier hokken in deze afdeling werden vrijgehouden als noodopvang.

\subsection{Voeding en drinkwaterverstrekking}

\section{Kraamstal}

In de kraamstal kregen de zeugen tweemaal daags ('s ochtends tussen 8.00 en 10.00 u en 's middags tussen 14.30 en $16.30 \mathrm{u}$ ) standaard lactovoer $(\mathrm{EW}=1,08)$ verstrekt volgens het standaard voerschema van VIC Sterksel. Voor het werpen kregen de gelten 3,0 kg voer per dag en de zeugen $3,25 \mathrm{~kg}$. Na het werpen is voergift geleidelijk verhoogd tot maximaal 7,5 kg voer per dag. Drinkwater stond onbeperkt ter beschikking via een drinknippel in de trog.

De zuigende biggen in de vier proefbehandelingen zijn als volgt gevoerd:

1. Controlevoer: De biggen kregen vanaf circa 4 dagen leeftijd creepfeed verstrekt. Rond dag 18 en 19 na geboorte kregen ze creepfeed gemengd met het controle speenvoer. Vanaf 20 dagen leeftijd tot spenen is alleen het controle speenvoer verstrekt.

2. Vezelrijk voer: De biggen kregen vanaf circa 4 dagen leeftijd een vezelrijke brok (XL-korrel) verstrekt. Tevens is vanaf circa 4 dagen leeftijd creepfeed verstrekt. Het creepfeed is in toenemende hoeveelheid door de XL-korrel gemengd. Rond dag 18 en 19 na geboorte kregen ze creepfeed gemengd met een speenvoer met extra vezels plus de XL-korrel verstrekt. Vanaf dag 20 tot spenen kregen ze alleen het speenvoer met extra vezels plus de $\mathrm{XL}$-korrel verstrekt.

3. Voer met extra aminozuren: De biggen kregen vanaf circa 4 dagen leeftijd creepfeed verstrekt. Rond dag 18 en 19 na geboorte kregen ze creepfeed gemengd met speenvoer met extra aminozuren. Vanaf 20 dagen leeftijd tot spenen kregen ze alleen het speenvoer met extra aminozuren verstrekt.

4. Vezelrijk voer met extra aminozuren: De biggen kregen vanaf circa 4 dagen leeftijd XL-korrel verstrekt. Tevens is vanaf circa 4 dagen leeftijd creepfeed verstrekt. Het creepfeed is in toenemende hoeveelheid door de XL-korrel gemengd. Rond dag 18 en 19 na geboorte kregen ze creepfeed gemengd met een speenvoer met extra vezels en extra aminozuren plus de $\mathrm{XL}$-korrel verstrekt. Vanaf dag 20 tot spenen kregen ze alleen het speenvoer met extra vezels en extra aminozuren plus de XL-korrel verstrekt.

Bij alle tomen in het onderzoek is op dezelfde dag gestart met het bijvoeren van de biggen. Ook de voeroverschakeling vond bij alle tomen op dezelfde dagen plaats. Het creepfeed en de XL-korrel zijn tot de voeroverschakeling vier keer per dag verstrekt in een rond bijzetbakje in het hok, de speenvoeders en de XL-korrel vanaf de voeroverschakeling twee keer daags. Drinkwater stond onbeperkt ter beschikking via een drinknippel. De grondstoffen- en nutriëntensamenstelling van de speenvoeders zijn weergegeven in bijlage 1. De EW van alle speenvoeders was hetzelfde. 


\section{Biggenopfokstal}

De gespeende biggen kregen de eerste 14 dagen na spenen speenvoer verstrekt. Daarna zijn ze abrupt overgeschakeld op biggenopfokkorrel. Aan de gespeende biggen in de vier proefbehandelingen zijn de volgende voeders verstrekt:

1) Controlevoer: de biggen kregen het controle speenvoer en de controle opfokkorrel.

2) Vezelrijk voer: de biggen kregen speenvoer en opfokkorrel met extra vezels.

3) Voer met extra aminozuren: de biggen kregen speenvoer en opfokkorrel met extra aminozuren.

4) Vezelrijk voer met extra aminozuren: de biggen kregen speenvoer en opfokkorrel met extra vezels en extra aminozuren.

De gespeende biggen zijn onbeperkt gevoerd via een 2-vaksdroogvoerbak ( 2 vreetplaatsen voor 12 dieren). De eerste 4 dagen na spenen kregen de biggen het speenvoer ook verstrekt via een rond bijzetbakje met ca. 10 vreetplaatsen om de voeropname te stimuleren. Drinkwater stond onbeperkt ter beschikking via een drinkbakje in het hok. De grondstoffen- en nutriëntensamenstelling van de speenvoeders en opfokvoeders zijn weergegeven in bijlage 1. De EW van alle opfokkorrels was hetzelfde.

\section{Vleesvarkensstal}

In alle proefbehandelingen is aan de vleesvarkens gedurende de eerste vijf weken na opleg startvoer verstrekt. Vervolgens is abrupt overgeschakeld op tussenvoer, dat gedurende 4 weken is verstrekt. Daarna zijn de dieren abrupt overgeschakeld op eindvoer, dat tot afleveren is verstrekt. De volgende voeders zijn verstrekt:

1) Controlevoer: de vleesvarkens kregen controle startvoer, tussenvoer en eindvoer.

2) Vezelrijk voer: de vleesvarkens kregen een startvoer, tussenvoer en eindvoer met extra vezels.

3) Voer met extra aminozuren: de vleesvarkens kregen een startvoer, tussenvoer en eindvoer met extra aminozuren.

4) Vezelrijk voer met extra aminozuren: de vleesvarkens kregen een startvoer, tussenvoer en eindvoer met extra vezels en extra aminozuren.

De vleesvarkens zijn onbeperkt gevoerd via een 2-vaksdroogvoerbak (2 vreetplaatsen voor 12 dieren). Drinkwater was in alle hokken onbeperkt beschikbaar via een drinkbakje in het hok. De grondstoffen- en nutriëntensamenstelling van de voeders zijn weergegeven in bijlage 2 . De EW van alle start-, tussen- en eindvoeders was respectievelijk 1,12, 1,10 en 1,08.

\section{$2.5 \quad$ Huisvesting en klimaat}

\section{Kraamstal}

Een week voor werpen werden de zeugen naar de kraamstal verplaatst. De kraamafdelingen hadden elk 12 hokken van 1,80 m breed en 2,40 m diep. De vloer bestond vanaf de voergang gezien uit een geplastificeerd rooster van 1,85 m diep en een metalen driekant rooster van 0,55 $\mathrm{m}$. Het vloergedeelte onder de zeug was 0,65 m breed. In alle kraamafdelingen kwam de verse lucht binnen via een verlaagde luchtinlaat onder de mestpannen. Het ventilatieniveau was ingesteld conform de richtlijn van het Klimaatplatform. Kunstlicht was aan van circa 7.30 tot 16.30 uur. Daarnaast brandde er een controlelamp van 7.00 tot 20.00 uur.

\section{Biggenopfokstal}

De biggenopfokafdelingen hadden elk 8 hokken voor 12 gespeende biggen. In alle afdelingen waren de hokken 2,20 m diep en 2,20 m breed en hadden een volledig kunststof roostervloer. De afdelingen werden mechanisch geventileerd, waarbij het ventilatieniveau was ingesteld conform de richtlijn van het Klimaatplatform. Kunstlicht was aan van 7.00 tot 20.00 uur.

\section{Vleesvarkensstal}

De vleesvarkensafdelingen hadden elk 12 hokken voor 12 vleesvarkens. De hokken waren 2,5 m breed en 5,0 m diep. De vloer bestond vanaf de controlegang gezien uit een smal betonrooster, een bolle dichte vloer en een breed metalen driekantrooster. Alle afdelingen werden mechanisch 
geventileerd. De verse ventilatielucht werd aangevoerd via ondergrondse luchtinlaat en kwam via de controlegang in de hokken. Het ventilatieniveau was ingesteld conform de richtlijn van het Klimaatplatform. Kunstlicht was aan van circa 7.30 tot 16.30 uur. Daarnaast brandde er een controlelamp van 7.00 tot 20.00 uur.

\subsection{Hokverrijking}

In de kraamstal is als hokverrijking het volgende verstrekt:

- Biggen: een jute doek (breed opgehangen aan de hokafscheiding; zie foto 1);

- Zeug: een ketting met houten blokje plus een PVC-buis op het hekwerk. Daarnaast kreeg de zeug een jute zak als nestbouwmateriaal.

In de hokken met gespeende biggen en vleesvarkens is als hokverrijking het volgende verstrekt:

- Jute doek (gespeende biggen; breed opgehangen; foto 2) en jute zak (vleesvarkens; opgehangen aan een punt; foto 3);

- $\quad$ Lange ketting met 3 bouten hangend tot op de vloer;

- Ketting met een houten blokje (circa $10 \mathrm{~cm}$ lang en $5 \mathrm{~cm}$ breed) op circa $20 \mathrm{~cm}$ hoogte (bij de vleesvarkens was dit een boomstammetje op circa $40 \mathrm{~cm}$ hoogte; foto 4 ).

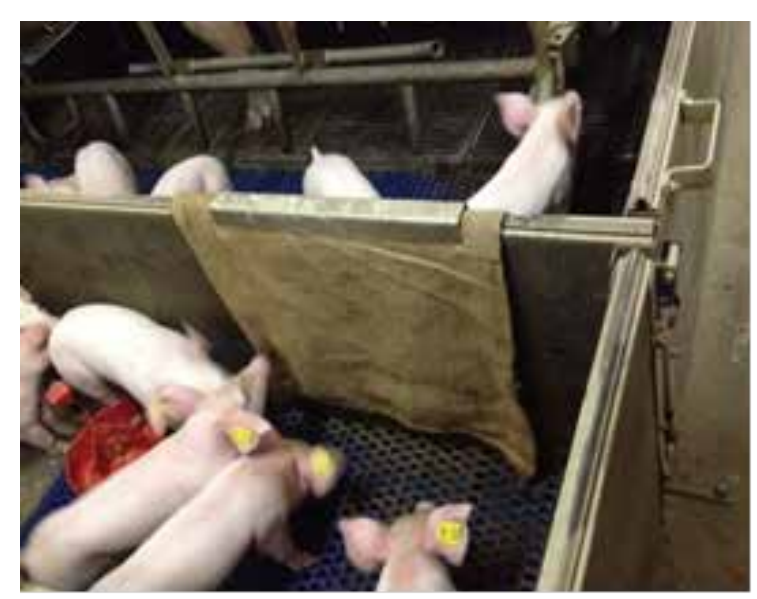

Foto 1 Jute zak voor biggen in kraamhok

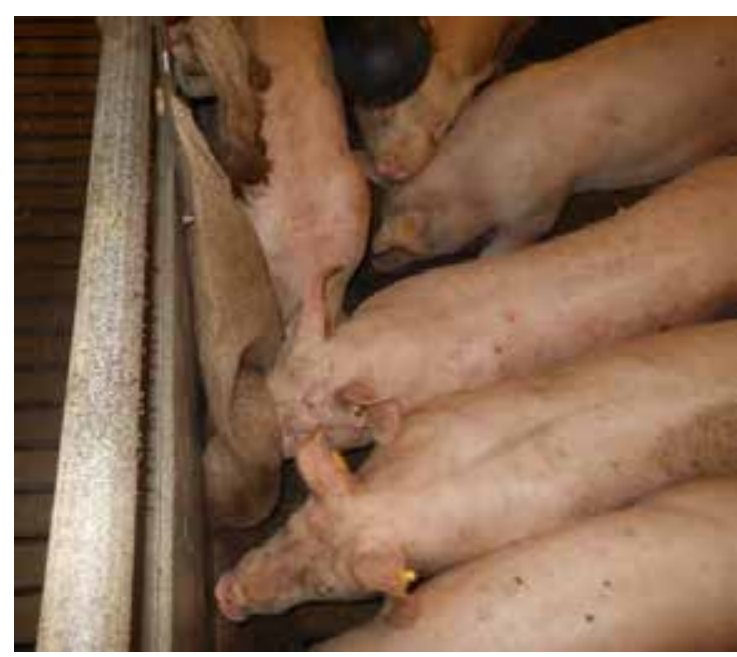

Foto 3 Jute zak voor vleesvarkens

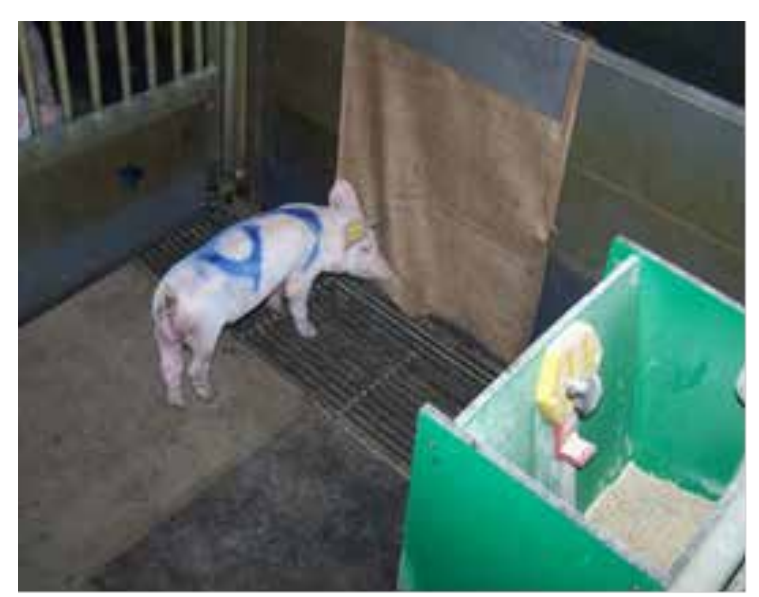

Foto 2 Jute zak voor gespeende biggen

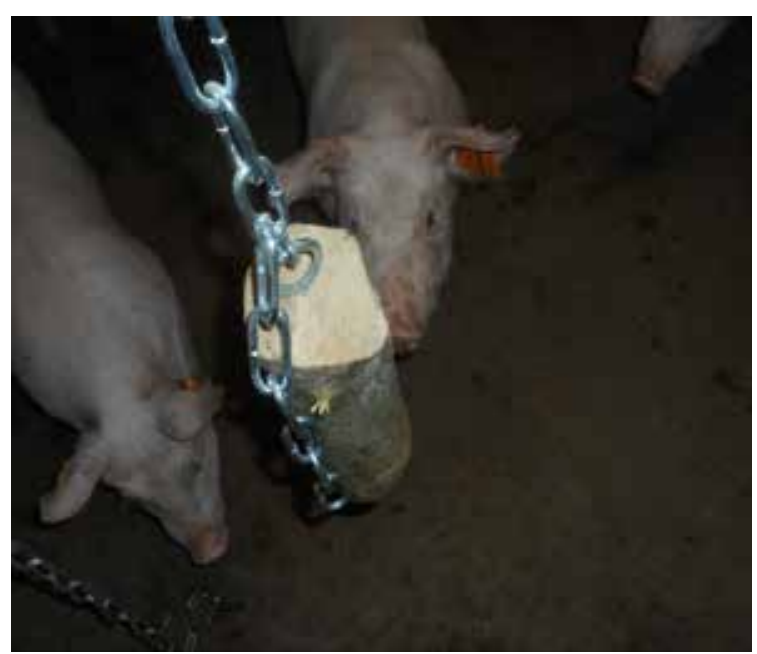

Foto 4 Boomstammetje voor vleesvarkens 


\subsection{Afleverstrategie}

Bij levering van de varkens naar het slachthuis is gestreefd naar een gemiddeld geslacht gewicht van circa $93 \mathrm{~kg}$ voor zowel de beren als de zeugjes, met een spreiding die is toegestaan binnen het gewichtstraject van het concept waarin ze geleverd werden. Dit betekende voor de zeugjes een geslacht gewicht tussen de 82 en $103 \mathrm{~kg}$, en voor de beren tussen de 80 en $100 \mathrm{~kg}$. De varkens zijn nuchter geleverd. De dieren binnen een hok en binnen een afdeling zijn in twee keer geleverd.

\subsection{Plan van aanpak bij staart-, oor- of flankschade}

Tweemaal daags werden vanaf de voergang de staarten, oren en flanken van alle dieren (zowel de zuigende biggen, de gespeende biggen als de vleesvarkens) gecontroleerd. Beoordeeld is of er dieren waren met een afwijkende staarthouding (hangende staart of staart tegen achterkant geklemd) of dieren met een staart-, oor- of flankbeschadiging. Als er dieren met een beschadiging met vers bloed aan staart, oren of flank of dieren met een afwijkende staarthouding werden gezien, werd in het hok gestapt om de staarten, oren en flanken van alle dieren in dat hok nauwkeurig te controleren.

Bij zichtbaar bijtgedrag is een rode hokkaart op de hokafscheiding gehangen. Op de hokkaarten zijn de waarnemingen en maatregelen vastgelegd die op hokniveau zijn uitgevoerd. Een oranje hokkaart (zie bijlage 3) werd opgehangen wanneer er sprake was van een verdachte situatie (vermoeden van een verhoogd risico op staartbijten, vanwege gedrag van de dieren en/of hangende staarten of bijterij in het verleden). Bij een verdachte situatie werd nog géén vangnet (zijnde aanvullende maatregelen) ingezet. Een rode hokkaart (zie bijlage 4) werd opgehangen als er duidelijk bijtgedrag werd waargenomen (dieren beten elkaar en/of er waren verse bijtpuntjes c.q. verwondingen met vers bloed zichtbaar). Bij constatering van duidelijk bijtgedrag werd ook een vangnet ingezet. Dit vangnet bestond in de biggenopfokfase uit het ophangen van twee verticale touwen in het hok (tot op de grond) en het twee maal daags verstrekken van een halve schep luzerne in een rond bakje (foto 5). $\mathrm{Bij}$ de vleesvarkens bestond het vangnet uit het ophangen van twee verticale touwen in het hok (tot op de grond) en het twee maal daags verstrekken van een hele schep luzerne in een mand die boven de dichte vloer werd opgehangen (onderkant van de mand hing net boven kophoogte van staande dieren; foto 6).

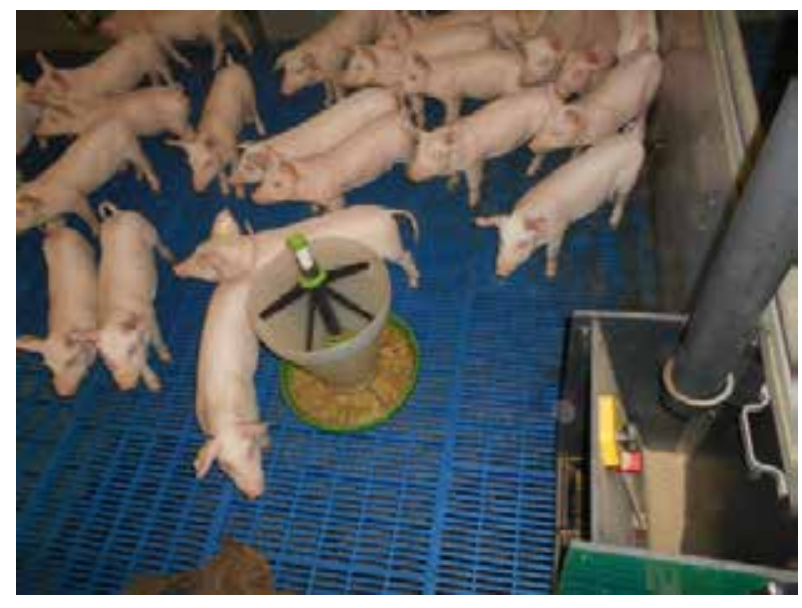

Foto 5 Luzerne in rond bakje bij biggen

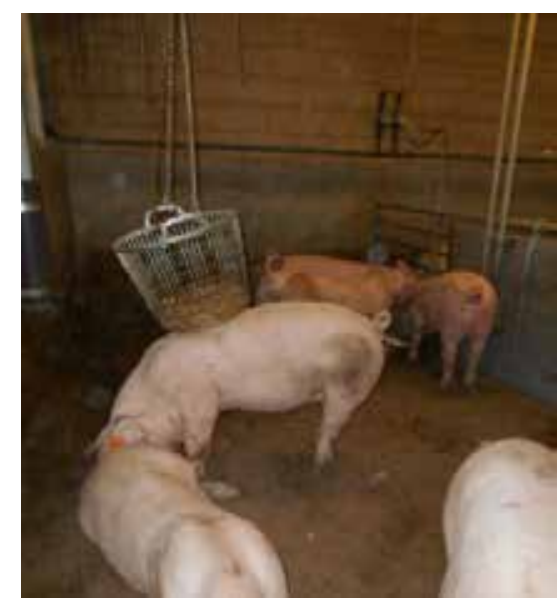

Foto 6 Luzerne in mand bij vleesvarkens

Als er een duidelijke bijter kon worden aangewezen dan is dit dier uit het hok en uit de proef gehaald en naar de noodopvang verplaatst. Van elk dier met een bijtwond aan staart, oren en/of flanken is dagelijks een dierkaart (zie bijlage 5) ingevuld. Op deze dierkaart zijn de beoordeling van de wond (wondgrootte, vers bloed zichtbaar, korstvorming op de wond en necrose van weefsel) en de uitgevoerde behandelingen vastgelegd. De dieren konden, naar inzicht van de dierverzorgers, worden behandeld met pleisterspray, jodium of acederm spray op het gebied rondom de wond (staartbasis, oor of flanken) en/of worden gesprayd met citroenspray. Bij een ernstige wond en/of tekenen van ontsteking (staart rood, dik en/of warm) of algehele ziekte werd aanvullend antibiotica toegediend. Bij 
een ernstige wond die na 3 à 4 dagen niet verbeterde of erger werd, of wanneer het dier algeheel ziek was van de verwonding, is het dier naar een noodopvanghok verplaatst en uit de proef gehaald. Als er drie opéénvolgende dagen geen vers bloed werd gezien bij de dieren met een bijtwond is gestopt met het inzetten van het vangnet en zijn de touwen en luzerne weggehaald. Twee dagen later is gestopt met het invullen van de dierkaart.

\subsection{Waarnemingen}

Tijdens het onderzoek zijn de volgende waarnemingen uitgevoerd:

Dier gerelateerde waarnemingen:

- Totaal aantal geboren biggen en aantal levend en dood geboren biggen.

- Gewicht van de individuele dieren bij geboorte, daags voor opleg in de biggenopfokstal (daags voor spenen), twee weken na opleg in de biggenopfokstal (bij overschakelen van speenvoer naar opfokvoer), vijf weken na opleg in de biggenopfokstal (bij opleg in de vleesvarkensstal), bij overschakelen van startvoer naar tussenvoer, bij overschakelen van tussenvoer naar eindvoer en daags voor afleveren.

- Voeropname per voersoort op hokniveau van de biggen in de kraamstal, de biggenopfokstal en de vleesvarkensstal.

- Slachtgegevens (slachtgewicht, vleespercentage, spierdikte, spekdikte).

- Bij uitval van een dier (zowel bij natuurlijke dood als euthanasie) zijn het diernummer, de datum, het gewicht, de mogelijke doodsoorzaak en de voeropname tot dan toe in het hok genoteerd.

- $\quad$ Bij het verplaatsen van een dier naar de noodopvang zijn afdeling, hok, diernummer, de datum, het gewicht, de staartscore en de voeropname tot dan toe in het hok vastgelegd.

- Bij veterinaire behandeling van een dier zijn het diernummer, de datum, symptomen/diagnose, gebruikte medicijnen, dosering en aantal dagen van de behandeling vastgelegd.

\section{Specifieke waarnemingen en eventuele interventies:}

- Tweemaal daags werden vanaf de voergang de staarten, oren en flanken van alle dieren (zowel de zuigende biggen, de gespeende biggen als de vleesvarkens) gecontroleerd. Beoordeeld is of er dieren waren met een afwijkende staarthouding (hangende staart of staart tegen achterhand geklemd) of met een staart-, oor- of flankbeschadiging. In geval van dieren met een beschadiging met vers bloed aan staart, oor of flank of dieren met een afwijkende staarthouding werd de controle uitgebreid door in het hok te stappen en bij alle dieren de staart, oren en flanken nauwkeurig te controleren (zie paragraaf 2.8).

- $\quad$ Op een leeftijd van 4 weken (bij spenen), 9 weken (bij opleg in de vleesvarkensstal), 14 weken (bij de overgang van startvoer naar tussenvoer), 18 weken (bij de overgang van tussenvoer naar eindvoer) en daags voor afleveren zijn alle individuele dieren beoordeeld op:

o Staartbeschadigingen: 1 = geen beschadiging zichtbaar; 2 = haar gedeeltelijk of volledig verwijderd; 3 = bijtpuntjes; 4 = zichtbare verwonding;

o Staartlengte wel of niet intact: 1 = staart intact, er mist geen deel van de staart; 2 = deel van de staart ontbreekt;

o Oorbeschadigingen: 1 = geen beschadiging zichtbaar; 2 = beschadiging aan punt/bovenrand; 3 = beschadiging aan onderrand; 4 = beschadiging aan punt, boven- en onderrand; 5 = deel van oor mist; $6=$ necrose van het oor;

o Flankbeschadigingen: 1 = geen beschadiging; 2 = kleine beschadiging $(\max 2 \mathrm{~cm}$ diameter); 3 = grote beschadiging (meer dan $2 \mathrm{~cm}$ ).

- Op een leeftijd van 7 weken (twee weken voor opleg in de vleesvarkensstal) en 21 weken (drie weken na de overschakeling van tussenvoer naar eindvoer) zijn live gedragswaarnemingen bij de dieren verricht. Elk hok werd gedurende 8 keer 10 minuten geobserveerd. De observaties waren verdeeld over twee of drie dagen. Tijdens de observaties werd het aantal keer staartbijten (kauwen aan of bijten in de staart van een hokgenoot), 
oorbijten (kauwen aan of bijten in het oor van een hokgenoot) en ander type bijten (kauwen aan of bijten in elk willekeurig lichaamsdeel, behalve staart of oor) genoteerd.

- Van elk dier met een aangebeten staart, oor of flank is dagelijks een dierkaart ingevuld (zie paragraaf 2.8).

- Als een hok een oranje of rode kaart kreeg zijn het hoknummer en de start- en einddatum van de oranje of rode kaart geregistreerd.

- Het verbruik van basis hokverrijkingsmateriaal (jute zakken) en het verbruik van extra hokverrijkingsmateriaal bij inzet van het vangnet (verstrekte meters touw en aantal scheppen luzerne) is genoteerd op hokniveau.

\section{Overige waarnemingen:}

- De temperatuur in de afdeling is met een logger elke 10 minuten geregistreerd.

- Bijzonderheden en eventuele storingen zijn in een logboek vastgelegd.

\subsection{Gegevensverwerking}

\subsubsection{Statistische analyse van de technische resultaten}

De resultaten zijn geanalyseerd met behulp van variantie-analyse (Genstat, 2013).

Kraamstal

Het aantal levend en dood geboren biggen en de groei en voeropname van de biggen tijdens de zoogperiode zijn op hokniveau geanalyseerd met het volgende model:

$\mathrm{Y}=\mu+$ ronde + kraamafdeling + wel/geen extra vezels + wel/geen extra aminozuren + wel/geen extra vezels $\mathrm{x}$ wel/geen extra aminozuren + rest

Als covariabele is de pariteit van de zeug meegenomen.

Het aantal uitgevallen dieren en veterinair behandelde dieren zijn geanalyseerd met glimmix met binaire verdeling en logit link functie.

Biggenopfokstal

De groei, voeropname en voederconversie van de gespeende biggen zijn op hokniveau geanalyseerd met het volgende model:

$\mathrm{Y}=\mu+$ ronde + afdeling + wel/geen extra vezels + wel/geen extra aminozuren + wel/geen extra vezels $x$ wel/geen extra aminozuren + rest

Het aantal uitgevallen dieren en veterinair behandelde dieren zijn geanalyseerd met glimmix met binaire verdeling en logit link functie.

Vleesvarkensstal

De technische kengetallen (groei, voeropname, voederconversie) en slachtgegevens (vleespercentage, spierdikte en spekdikte) van de vleesvarkens zijn geanalyseerd op hokniveau. Het model zag er als volgt uit:

$\mathrm{Y}=\mu+$ ronde + vleesvarkensafdeling + wel/geen extra vezels + wel/geen extra aminozuren + wel/geen extra vezels $x$ wel/geen extra aminozuren + rest

Bij analyse van de slachtgegevens is het geslacht gewicht als covariabele opgenomen in het model. Het percentage uitgevallen dieren en het percentage veterinair behandelde dieren zijn geanalyseerd met glimmix met binaire verdeling en logit link functie. 


\subsubsection{Staart-, oor- en flankbeschadigingen en gedragswaarnemingen}

Het percentage dieren per score voor staart-, oor- en flankbeschadigingen is geanalyseerd op hokniveau met glimmix met binaire verdeling en logit link functie.

De gedragswaarnemingen zijn geanalyseerd op hokniveau. Het totaal aantal keer in een hok dat respectievelijk staartbijten, oorbijten en ander bijtgedrag is gescoord tijdens de 8 keer 10 minuten waarnemen is geanalyseerd met een regressiemodel. Bij kenmerken die niet normaal verdeeld waren, is voor analyse een logtransformatie toegepast. In het model is ronde als random factor opgenomen, het aantal dieren in het hok tijdens de waarnemingen als covariabele en wel/geen extra vezels en wel/geen extra aminozuren als factor.

\subsubsection{Hok- en dierkaarten}

Het aantal hok-en dierkaarten per fase (kraamfase, biggenopfokfase en vleesvarkensfase) en per voerbehandeling, de inzet van het vangnet (met hoeveelheid en soort ingezette materialen (touw, luzerne) en de duur (aantal dagen) van bijterij c.q. herstel zijn beschrijvend weergegeven. 


\section{Resultaten}

\subsection{Technische resultaten}

\subsubsection{Zoogperiode}

In tabel 1 zijn de technische resultaten van de biggen in de zoogperiode weergegeven voor de hoofdeffecten wel/geen extra vezels en wel/geen extra aminozuren. De resultaten per proefbehandeling zijn weergegeven in bijlage 6 .

Tabel 1 Technische resultaten van zuigende biggen die wel of geen extra vezels en wel of geen extra aminozuren in het voer kregen

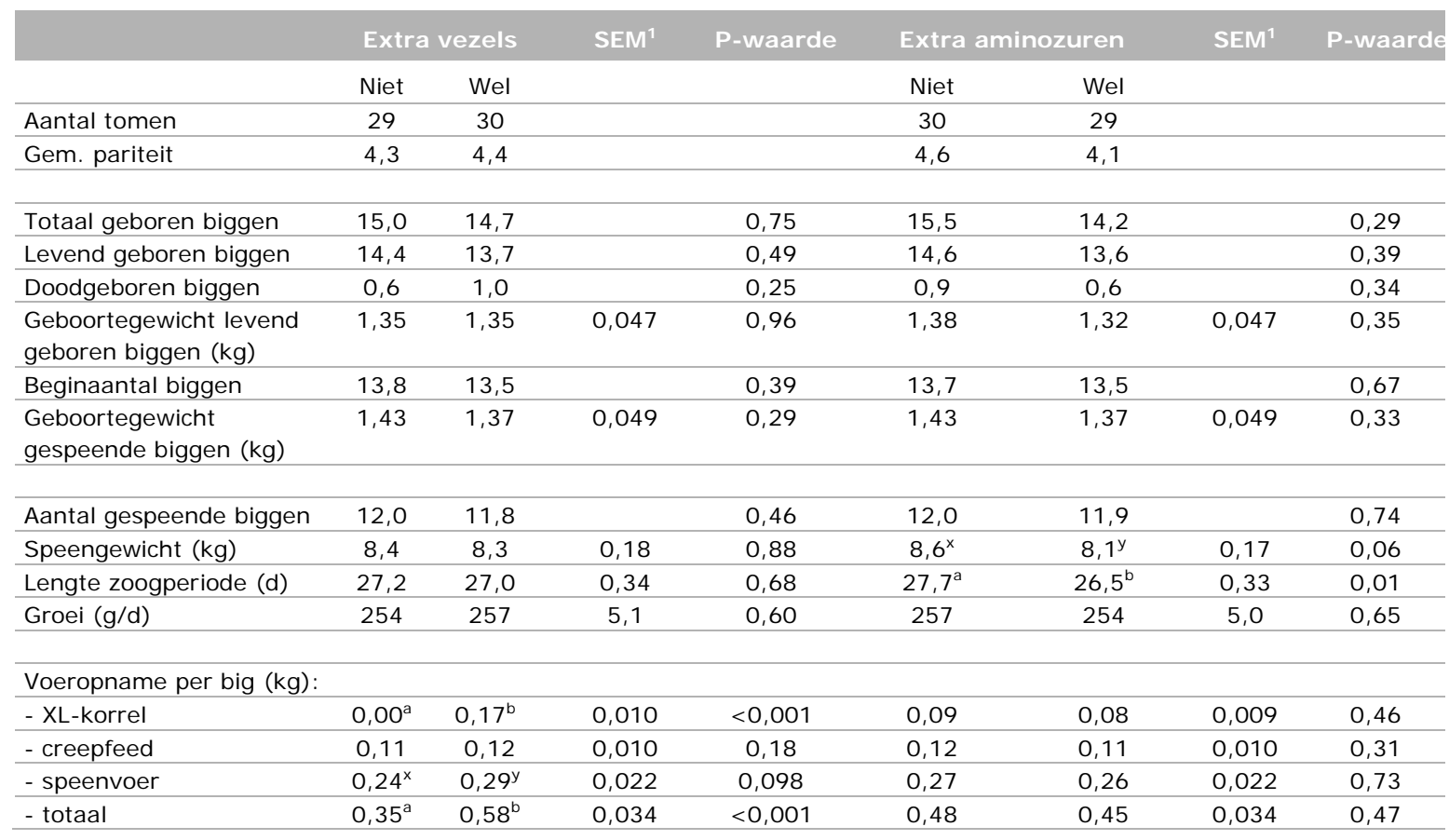

${ }^{1}$ SEM = gepoolde standard error van het gemiddelde; ${ }^{a, b}$ Gemiddelden met een verschillende letter binnen een rij zijn verschillend $(p<0,05)$;

$x, y$ Gemiddelden met een verschillende letter binnen een rij tenderen naar verschillend $(p<0,10)$

Uit tabel 1 blijkt dat de zuigende biggen die extra vezels in het voer kregen meer speenvoer hebben opgenomen dan de biggen die geen extra vezels in het voer kregen. De groei van de biggen die wel of geen extra vezels kregen was vergelijkbaar.

De biggen die extra aminozuren in het speenvoer kregen waren 0,5 kg lichter en 1,2 dag jonger bij spenen dan de biggen die geen extra aminozuren kregen.

\subsubsection{Biggenopfokperiode}

In tabel 2 zijn de technische resultaten van de biggen over de gehele opfokperiode weergegeven voor de hoofdeffecten wel/geen extra vezels en wel/geen extra aminozuren. De technische resultaten in de eerste twee weken (speenvoerfase) en laatste drie weken (opfokvoerfase) zijn weergegeven in tabel 3. De resultaten per proefbehandeling zijn weergegeven in bijlage 7. 

vezels en wel of geen extra aminozuren in het voer kregen

\begin{tabular}{|c|c|c|c|c|c|c|c|c|}
\hline & \multicolumn{2}{|c|}{ Extra vezels } & \multirow[t]{2}{*}{ SEM $M^{1}$} & \multirow[t]{2}{*}{ P-waarde } & \multicolumn{2}{|c|}{ Extra aminozuren } & \multirow[t]{2}{*}{ SEM $^{1}$} & \multirow[t]{2}{*}{ P-waarde } \\
\hline & Niet & Wel & & & Niet & Wel & & \\
\hline Aantal hokken & 24 & $23^{2}$ & & & $23^{2}$ & 24 & & \\
\hline Speengewicht (kg) & 8,7 & 8,5 & & & 8,7 & 8,5 & & \\
\hline Groei (g/d) & 439 & 452 & 7,4 & 0,18 & $458^{a}$ & $433^{b}$ & 7,4 & 0,02 \\
\hline Voeropname $(\mathrm{kg} / \mathrm{d})$ & 0,59 & 0,60 & 0,010 & 0,35 & 0,61 & 0,59 & 0,010 & 0,18 \\
\hline Voederconversie $^{2}$ & 1,35 & 1,33 & 0,010 & 0,43 & $1,32^{\mathrm{a}}$ & $1,35^{b}$ & 0,010 & 0,04 \\
\hline
\end{tabular}

Uit tabel 2 blijkt dat er geen verschillen waren in groei, voeropname en voederconversie tussen gespeende biggen die wel of geen extra vezels in het voer kregen.

De biggen die extra aminozuren in het voer kregen zijn langzamer gegroeid en hadden een ongunstigere voederconversie dan de biggen die geen extra aminozuren in het voer kregen. De ongunstigere voederconversie werd alleen gevonden bij de biggen die het controlevoer met extra aminozuren kregen en niet bij de biggen die het vezelrijke voer met extra aminozuren kregen (zie bijlage 7).

Tabel 3 Technische resultaten in de speenvoerfase en de opfokvoerfase van gespeende biggen die wel of geen extra vezels en wel of geen extra aminozuren in het voer kregen

\begin{tabular}{|c|c|c|c|c|c|c|c|c|}
\hline & \multicolumn{2}{|c|}{ Extra vezels } & SEM ${ }^{1}$ & P-waarde & \multicolumn{2}{|c|}{ Extra aminozuren } & $\operatorname{SEM}^{1}$ & P-waarde \\
\hline Aantal hokken & 24 & $23^{2}$ & & & $23^{2}$ & 24 & & \\
\hline \multicolumn{9}{|c|}{ Speenvoerfase (D0 - D14): } \\
\hline Aantal dagen & 14 & 14 & & & 14 & 14 & & \\
\hline Groei (g/d) & 255 & 266 & 8,3 & 0,33 & $278^{a}$ & $243^{b}$ & 8,3 & 0,003 \\
\hline Voeropname (kg/d) & 0,30 & 0,31 & 0,010 & 0,34 & $0,32^{a}$ & $0,29^{b}$ & 0,010 & 0,05 \\
\hline Voederconversie & 1,19 & 1,19 & 0,021 & 0,89 & $1,16^{\mathrm{a}}$ & $1,22^{\mathrm{b}}$ & 0,021 & 0,05 \\
\hline Groei (g/d) & 561 & 577 & 8,2 & 0,18 & 578 & 560 & 8,2 & 0,13 \\
\hline Voeropname (kg/d) & 0,78 & 0,80 & 0,012 & 0,42 & 0,80 & 0,78 & 0,012 & 0,41 \\
\hline Voederconversie $^{2}$ & 1,40 & 1,38 & 0,011 & 0,40 & 1,38 & 1,40 & 0,011 & 0,30 \\
\hline
\end{tabular}

${ }^{1} \mathrm{SEM}=$ gepoolde standard error van het gemiddelde; ${ }^{2}$ Eén hok is voortijdig uit het onderzoek genomen vanwege ernstig vechten;

a,b Gemiddelden met een verschillende letter binnen een rij zijn verschillend $(p<0,05) ;{ }^{2}$ Significante interactie voor voederconversie $(1,36,1,41$, 1,43 en 1,36 voor behandeling $1 \mathrm{t} / \mathrm{m} \mathrm{4)}$

Uit tabel 3 blijkt dat er zowel tijdens de speenvoer- als de opfokvoerfase geen verschillen waren in groei, voeropname en voederconversie tussen gespeende biggen die wel of geen extra vezels in het voer kregen.

De biggen die extra aminozuren in het voer kregen namen tijdens de speenvoerfase minder voer op, groeiden langzamer en hadden een ongunstigere voederconversie dan de biggen die geen extra aminozuren in het voer kregen. Tijdens de opfokvoerfase waren er geen verschillen in groei, 
voeropname en voederconversie tussen de biggen die wel of geen extra aminozuren in het voer kregen. Wel was er een significantie interactie tussen extra vezels en extra aminozuren in het voer voor het kenmerk voederconversie. De biggen die het controlevoer of het vezelrijke voer met extra aminozuren kregen hadden een gunstigere voederconversie dan de biggen die alleen extra vezels of alleen extra aminozuren kregen (zie bijlage 7).

\subsubsection{Vleesvarkensfase}

In tabel 4 zijn de technische resultaten van de vleesvarkens over de gehele vleesvarkensfase weergegeven voor de hoofdeffecten wel/geen extra vezels en wel/geen extra aminozuren. De technische resultaten in de eerste vijf weken (startvoerfase), de volgende vier weken (tussenvoerfase) en de periode tot afleveren (eindvoerfase) zijn weergegeven in tabel 5. De resultaten per proefbehandeling zijn weergegeven in bijlage 8 .

Tabel 4 Technische resultaten over de gehele vleesvarkensfase van vleesvarkens die wel of geen extra vezels en wel of geen extra aminozuren in het voer kregen

\begin{tabular}{|c|c|c|c|c|c|c|c|c|}
\hline & \multicolumn{2}{|c|}{ Extra vezels } & \multirow[t]{2}{*}{$S E M^{1}$} & \multirow[t]{2}{*}{ P-waarde } & \multicolumn{2}{|c|}{ Extra aminozuren } & \multirow[t]{2}{*}{ SEM ${ }^{1}$} & \multirow[t]{2}{*}{ P-waarde } \\
\hline & Niet & Wel & & & Niet & Wel & & \\
\hline Aantal hokken & 24 & 23 & & & 23 & 24 & & \\
\hline Aantal dieren & 271 & 261 & & & 256 & 276 & & \\
\hline \multicolumn{9}{|c|}{ Op basis van levend eindgewicht: } \\
\hline Aantal dagen & 107,1 & 108,1 & & & 107,3 & 107,9 & & \\
\hline Groei (g/d) & $930^{a}$ & $907^{\mathrm{b}}$ & 8,1 & 0,04 & 924 & 912 & 8,1 & 0,28 \\
\hline Voeropname (kg/d) & $2,29^{x}$ & $2,23^{y}$ & 0,023 & 0,06 & 2,27 & 2,25 & 0,023 & 0,43 \\
\hline Voederconversie & 2,46 & 2,46 & 0,013 & 0,86 & 2,46 & 2,46 & 0,013 & 0,82 \\
\hline EW-opname (/d) & $2,50^{x}$ & $2,43^{y}$ & 0,025 & 0,06 & 2,48 & 2,45 & 0,025 & 0,41 \\
\hline \multicolumn{9}{|c|}{ Op basis van berekend eindgewicht: } \\
\hline Berekend eindgewicht $(\mathrm{kg})$ & 120,2 & 118,2 & & & 119,9 & 118,6 & & \\
\hline Groei (g/d) & $909^{a}$ & $880^{b}$ & 8,1 & 0,01 & 899 & 890 & 8,1 & 0,46 \\
\hline Voederconversie & 2,52 & 2,53 & 0,014 & 0,45 & 2,53 & 2,52 & 0,014 & 0,73 \\
\hline
\end{tabular}

Uit tabel 4 blijkt dat de vleesvarkens die extra vezels in het voer kregen minder voer hebben opgenomen en langzamer zijn gegroeid dan de vleesvarkens die geen extra vezels in het voer kregen. Er was geen effect van extra vezels in het voer op de voederconversie.

Het verstrekken van extra aminozuren in het voer had geen effect op de groei, voeropname en voederconversie van de vleesvarkens van opleg tot afleveren.

Uit tabel 5 blijkt dat de vleesvarkens die extra vezels in het voer kregen, tijdens de startvoerfase minder voer hebben opgenomen en langzamer zijn gegroeid dan de vleesvarkens die geen extra vezels in het voer kregen. Er was tijdens de startvoerfase geen effect van extra vezels in het voer op de voederconversie. Tijdens de tussenvoer- en eindvoerfase (op basis van levend eindgewicht) waren er geen verschillen in groei, voeropname en voederconversie tussen de vleesvarkens die wel of geen extra vezels in het voer kregen.

De vleesvarkens die extra aminozuren in het voer kregen namen tijdens de startvoerfase minder voer op en groeiden langzamer dan de vleesvarkens die geen extra aminozuren in het voer kregen. Tijdens de tussenvoer- en eindvoerfase waren er geen verschillen in groei, voeropname en voederconversie tussen de vleesvarkens die wel of geen extra aminozuren in het voer kregen. Wel was er tijdens de tussenvoerfase een interactie tussen extra vezels en extra aminozuren voor het kenmerk voederconversie. De vleesvarkens die het vezelrijke voer met extra aminozuren kregen hadden een gunstigere voederconversie dan de vleesvarkens die het controlevoer met extra aminozuren kregen (zie bijlage 8). 
Tabel 5 Technische resultaten in de startvoer-, tussenvoer- en eindvoerfase van vleesvarkens die wel of geen extra vezels en wel of geen extra aminozuren in het voer kregen

\begin{tabular}{|c|c|c|c|c|c|c|c|c|}
\hline & \multicolumn{2}{|c|}{ Extra vezels } & \multirow[t]{2}{*}{$S E M^{1}$} & \multirow[t]{2}{*}{ P-waarde } & \multicolumn{2}{|c|}{ Extra aminozuren } & \multirow[t]{2}{*}{$S E M^{1}$} & \multirow[t]{2}{*}{ P-waarde } \\
\hline & Niet & Wel & & & Niet & Wel & & \\
\hline Aantal hokken & 24 & 23 & & & 23 & 24 & & \\
\hline Aantal dieren & 271 & 261 & & & 256 & 276 & & \\
\hline \multicolumn{9}{|l|}{ Startvoerfase (D0 - D35): } \\
\hline Opleggewicht (kg) & 23,8 & 24,2 & & & 24,5 & 23,5 & & \\
\hline Gewicht dag 35 (kg) & 51,9 & 51,1 & & & 52,5 & 50,5 & & \\
\hline Aantal dagen & 35 & 35 & & & 35 & 35 & & \\
\hline Groei (g/d) & $804^{a}$ & $769^{b}$ & 9,5 & 0,01 & $800^{a}$ & $773^{b}$ & 9,5 & 0,04 \\
\hline Voeropname (kg/d) & $1,61^{a}$ & $1,56^{\mathrm{b}}$ & 0,019 & 0,05 & $1,61^{\mathrm{a}}$ & $1,55^{b}$ & 0,019 & 0,02 \\
\hline Voederconversie & 2,00 & 2,02 & 0,014 & 0,30 & 2,02 & 2,00 & 0,014 & 0,39 \\
\hline \multicolumn{9}{|l|}{ Tussenvoerfase (D35 - D63): } \\
\hline Gewicht dag 35 (kg) & 51,9 & 51,1 & & & 52,5 & 50,5 & & \\
\hline Gewicht dag $63(\mathrm{~kg})$ & 78,0 & 76,8 & & & 78,5 & 76,4 & & \\
\hline Aantal dagen & 28 & 28 & & & 28 & 28 & & \\
\hline Groei (g/d) & 947 & 941 & 15,5 & 0,76 & 948 & 939 & 15,5 & 0,67 \\
\hline Voeropname $(\mathrm{kg} / \mathrm{d})$ & 2,30 & 2,24 & 0,033 & 0,18 & 2,28 & 2,26 & 0,033 & 0,71 \\
\hline Voederconversie $^{2}$ & 2,43 & 2,39 & 0,021 & 0,13 & 2,41 & 2,41 & 0,021 & 0,87 \\
\hline \multicolumn{9}{|c|}{ Eindvoerfase op basis van levend eindgewicht (D63-afleveren): } \\
\hline Gewicht dag 63 (kg) & 78,0 & 76,8 & & & 78,5 & 76,4 & & \\
\hline Levend eindgewicht $(\mathrm{kg})$ & 122,4 & 120,9 & & & 122,6 & 120,9 & & \\
\hline Aantal dagen & 44,1 & 45,1 & & & 44,3 & 44,9 & & \\
\hline Groei (g/d) & 1025 & 999 & 12,8 & 0,12 & 1014 & 1010 & 12,8 & 0,80 \\
\hline Voeropname (kg/d) & 2,85 & 2,79 & 0,036 & 0,17 & 2,82 & 2,82 & 0,036 & 0,91 \\
\hline Voederconversie & 2,79 & 2,79 & 0,028 & 0,87 & 2,79 & 2,79 & 0,028 & 0,99 \\
\hline \multicolumn{9}{|c|}{ Eindvoerfase op basis van berekend eindgewicht (D63-afleveren): } \\
\hline Berekend eindgewicht $(\mathrm{kg})$ & 120,2 & 118,2 & & & 119,9 & 118,6 & & \\
\hline Groei $(g / d)$ & $972^{a}$ & $932^{b}$ & 12,2 & 0,02 & 950 & 954 & 12,2 & 0,78 \\
\hline Voederconversie & 2,94 & 2,99 & 0,033 & 0,25 & 2,98 & 2,95 & 0,033 & 0,53 \\
\hline
\end{tabular}

${ }^{1}$ SEM = gepoolde standard error van het gemiddelde; ${ }^{a, b}$ Gemiddelden met een verschillende letter binnen een rij zijn verschillend $(p<0,05)$;

$x, y$ Gemiddelden met een verschillende letter binnen een rij tenderen naar verschillend $(p<0,10) ;{ }^{2}$ Significante interactie voor voederconversie

$(2,40,2,42,2,46$ en 2,36 voor behandeling $1 \mathrm{t} / \mathrm{m} \mathrm{4})$

In tabel 6 is de slachtkwaliteit van de vleesvarkens weergegeven voor de hoofdeffecten wel/geen extra vezels en wel/geen extra aminozuren. De resultaten per proefbehandeling zijn weergegeven in bijlage 9.

Tabel 6 Slachtkwaliteit van vleesvarkens die wel of geen extra vezels en wel of geen extra aminozuren in het voer kregen

\begin{tabular}{|c|c|c|c|c|c|c|c|c|}
\hline & \multicolumn{2}{|c|}{ Extra vezels } & \multirow[t]{2}{*}{ SEM1 } & \multirow[t]{2}{*}{ P-waarde } & \multicolumn{2}{|c|}{ Extra aminozuren } & \multirow[t]{2}{*}{ SEM1 } & \multirow[t]{2}{*}{ P-waarde } \\
\hline & Niet & Wel & & & Niet & Wel & & \\
\hline Aantal dieren geslacht & 249 & 253 & & & 242 & 260 & & \\
\hline Slachtgewicht (kg) & $94,8^{a}$ & $93,0^{\mathrm{b}}$ & 0,64 & 0,04 & 94,4 & 93,4 & 0,64 & 0,27 \\
\hline Vleespercentage & $58,9^{a}$ & $59,4^{b}$ & 0,15 & 0,03 & 59,2 & 59,1 & 0,14 & 0,87 \\
\hline Spierdikte (mm) & 65,0 & 65,0 & 0,48 & 0,96 & 65,0 & 65,0 & 0,45 & 0,99 \\
\hline Spekdikte (mm) & $14,2^{a}$ & $13,5^{b}$ & 0,22 & 0,03 & 13,8 & 13,8 & 0,21 & 0,87 \\
\hline Aanhoudingspercentage & $77,8^{a}$ & $77,3^{b}$ & 0,18 & 0,05 & 77,5 & 77,7 & 0,17 & 0,52 \\
\hline
\end{tabular}

${ }^{1}$ SEM = gepoolde standard error van het gemiddelde; ${ }^{a, b}$ Gemiddelden met een verschillende letter binnen een rij zijn verschillend $(p<0,05)$

Uit tabel 6 blijkt dat de vleesvarkens die extra vezels in het voer kregen bijna 2 kg lichter waren bij slachten en een hoger vleespercentage, dunner spek en een lager aanhoudingspercentage hadden dan de vleesvarkens die geen extra vezels kregen.

Er waren geen verschillen in vleespercentage, spierdikte, spekdikte en aanhoudingspercentage tussen vleesvarkens die wel of geen extra aminozuren in het voer kregen. 


\subsection{Veterinaire behandelingen en uitval}

\subsubsection{Zoogperiode}

In tabel 7 zijn het aantal uitgevallen en aantal veterinair behandelde biggen in de zoogperiode weergegeven voor de hoofdeffecten wel/geen extra vezels en wel/geen extra aminozuren. De resultaten per proefbehandeling zijn weergegeven in bijlage 10.

Tabel 7 Aantal uitgevallen en veterinair behandelde zuigende biggen die wel of geen extra vezels en wel of geen extra aminozuren in het voer kregen

\begin{tabular}{|c|c|c|c|c|c|c|}
\hline & \multicolumn{2}{|c|}{ Extra vezels } & P-waarde & \multicolumn{2}{|c|}{ Extra aminozuren } & P-waarde \\
\hline Aantal tomen & 29 & 30 & & 30 & 29 & \\
\hline Totaal uitgevallen & $50(12,5 \%)$ & $50(12,4 \%)$ & 0,94 & $53(12,9 \%)$ & $47(12,0 \%)$ & 0,94 \\
\hline - doodliggen & 11 & 10 & 0,77 & 14 & 7 & 0,16 \\
\hline - verhongerd & 5 & 12 & 0,97 & 5 & 12 & 0,97 \\
\hline - diarree & 2 & 0 & 1 & 0 & 2 & 1 \\
\hline - achterblijven in groei & 1 & 2 & 1 & 0 & 3 & 1 \\
\hline - diversen & 9 & 6 & 0,46 & 8 & 7 & 0,95 \\
\hline - kreupelheden & 12 & 15 & 0,37 & 11 & 16 & 0,55 \\
\hline - Streptococcus Suis-infectie & 3 & 3 & 1 & 3 & 3 & 1 \\
\hline - diversen & 4 & 2 & 1 & 2 & 4 & 1 \\
\hline Gemiddelde behandelduur (d) & 3,1 & 2,8 & 0,54 & 3,2 & 2,7 & 0,29 \\
\hline
\end{tabular}

1 Aantallen te laag om te toetsen

Uit tabel 7 blijkt dat er geen effect was van extra vezels in het voer of van extra aminozuren in het voer op het aantal uitgevallen en veterinair behandelde biggen. Ook was er geen effect op de reden van uitval of van veterinair behandelen.

\subsubsection{Biggenopfokperiode}

In tabel 8 zijn het aantal uitgevallen en aantal individueel veterinair behandelde biggen tijdens de opfokperiode weergegeven voor de hoofdeffecten wel/geen extra vezels en wel/geen extra aminozuren. De resultaten per proefbehandeling zijn weergegeven in bijlage 10. 
Tabel 8 Aantal uitgevallen en individueel veterinair behandelde gespeende biggen die wel of geen extra vezels en wel of geen extra aminozuren in het voer kregen

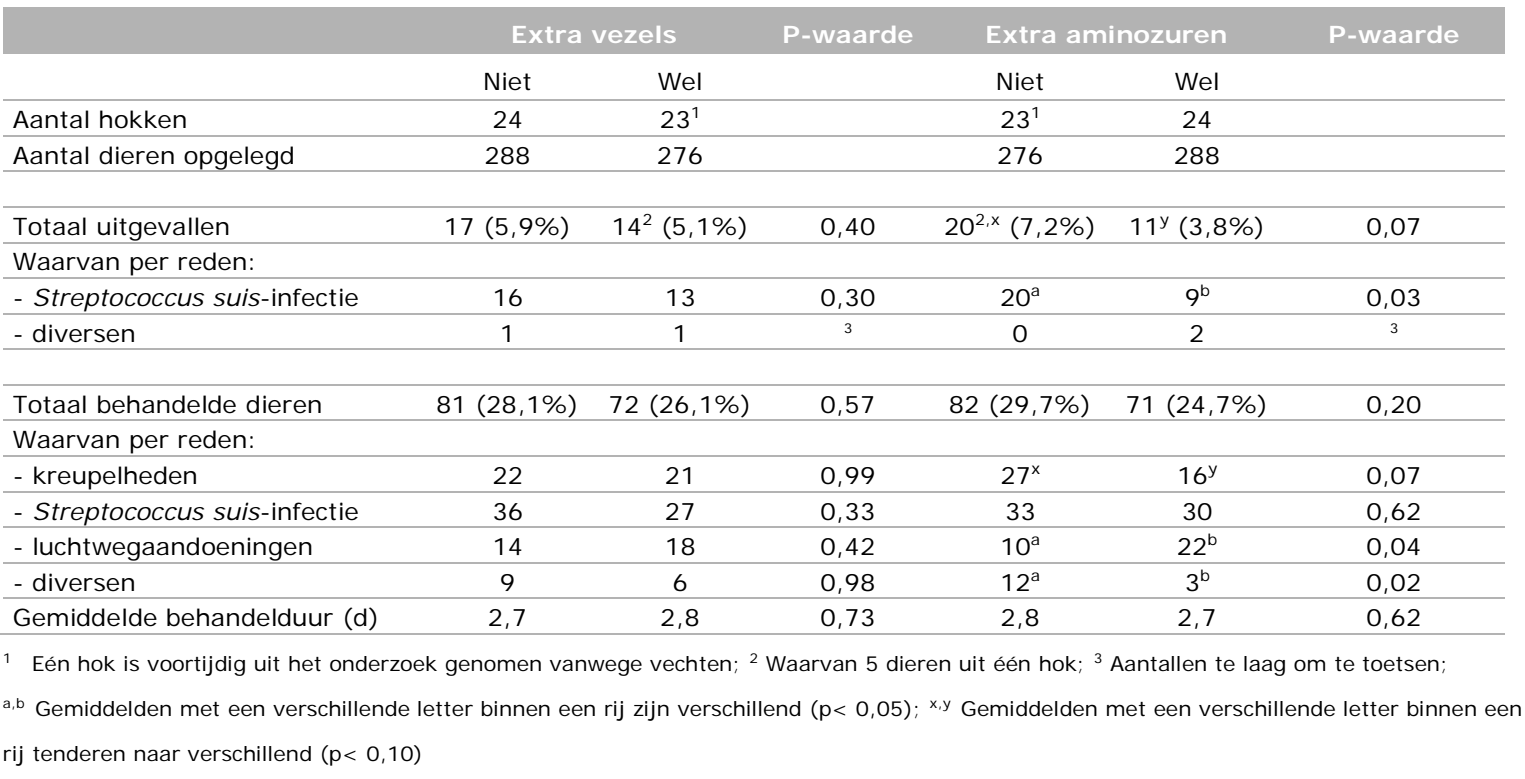

Uit tabel 8 blijkt dat het aantal uitgevallen en veterinair behandelde gespeende biggen en de reden van uitval en veterinair behandelen vergelijkbaar waren bij wel of geen extra vezels in het voer. De meeste biggen zijn uitgevallen vanwege een vermeende infectie met Streptococcus suis. De meeste biggen zijn veterinair behandeld vanwege kreupelheden, een infectie met Streptococcus suis en luchtwegaandoeningen.

Bij extra aminozuren in het voer was het aantal uitgevallen biggen (met name als gevolg van een Streptococcus suis infectie) lager dan bij geen extra aminozuren in het voer. De lagere uitval als gevolg van een Streptococcus suis infectie werd met name gevonden bij de biggen die het vezelrijke voer met extra aminozuren kregen en in mindere mate bij de biggen die het controlevoer met extra aminozuren kregen (zie bijlage 10). Er was geen effect van extra aminozuren in het voer op het aantal veterinair behandelde biggen. Wel was er een verschil in de reden van behandelen. Bij de biggen die extra aminozuren in het voer kregen zijn minder dieren behandeld vanwege kreupelheden en diverse redenen maar meer vanwege luchtwegaandoeningen.

Naast de individuele veterinaire behandelingen hebben alle dieren gedurende twee keer 5 dagen Octacilline door het drinkwater verstrekt gekregen in verband met een Streptococcus suis-infectie. In ronde 2 kregen alle biggen daarnaast 5 dagen Soludox door het drinkwater vanwege luchtwegproblemen.

\subsubsection{Vleesvarkensfase}

In tabel 9 zijn het aantal uitgevallen en aantal individueel veterinair behandelde vleesvarkens weergegeven voor de hoofdeffecten wel/geen extra vezels en wel/geen extra aminozuren. De resultaten per proefbehandeling zijn weergegeven in bijlage 10. De vleesvarkens die naar de noodopvang zijn verplaatst, zijn allemaal op de normale slachtleeftijd naar het slachthuis geleverd. 

behandelde vleesvarkens die wel of geen extra vezels en wel of geen extra aminozuren in het voer kregen

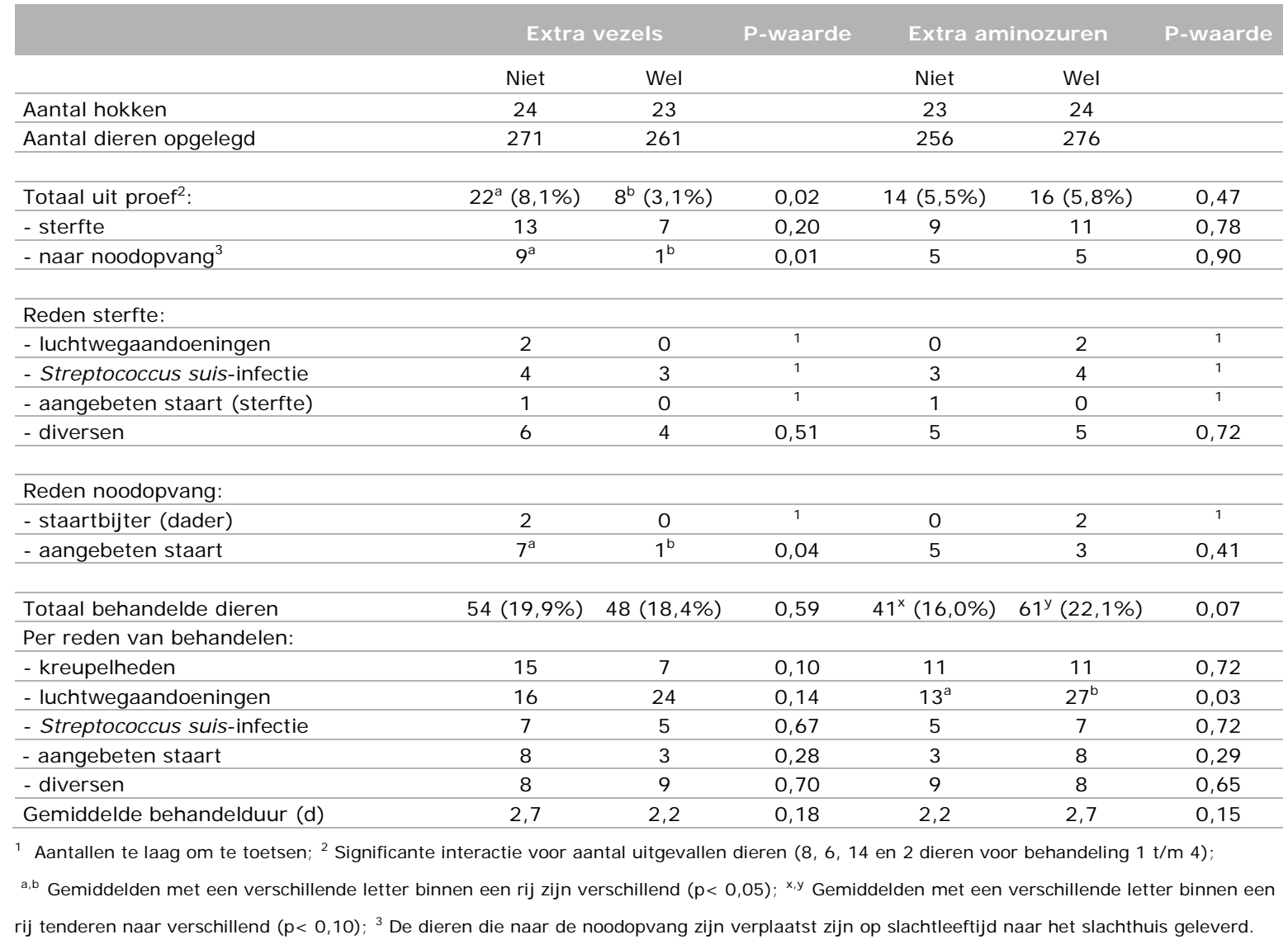

Uit tabel 9 blijkt dat bij extra vezels in het voer duidelijk minder dieren zijn uitgevallen dan bij geen extra vezels in het voer. Met name het aantal dieren dat als gevolg van een aangebeten staart naar de noodopvang is verplaatst was duidelijk lager. Er was geen effect van extra vezels in het voer op het aantal veterinair behandelde vleesvarkens.

Er was geen effect van extra aminozuren in het voer op het aantal uitgevallen vleesvarkens. Wel was er een interactie tussen extra vezels en extra aminozuren in het voer. Het aantal uitgevallen vleesvarkens was het laagst bij het vezelrijke voer met extra aminozuren en het hoogst bij het controle voer met extra aminozuren (2 versus 14 dieren; zie bijlage 10). Bij de vleesvarkens die extra aminozuren in het voer kregen zijn meer dieren veterinair behandeld (met name als gevolg van luchtwegaandoeningen) dan bij de vleesvarkens die geen extra aminozuren in het voer kregen.

\subsection{Staart-, oor en flankbeschadigingen}

In tabel 10 is het percentage dieren met staartbeschadigingen op 4, 9, 14 en 18 weken leeftijd en daags voor afleveren weergegeven voor de hoofdeffecten wel/geen extra vezels en wel/geen extra aminozuren. De resultaten per proefbehandeling zijn weergegeven in bijlage 11 . 
Tabel 10 Percentage dieren met staartbeschadigingen op 4, 9, 14 en 18 weken leeftijd en daags voor afleveren die wel of geen extra vezels en wel of geen extra aminozuren in het voer kregen

\begin{tabular}{|c|c|c|c|c|c|c|}
\hline & \multicolumn{2}{|c|}{ Extra vezels } & \multirow[t]{2}{*}{ P-waarde } & \multicolumn{2}{|c|}{ Extra aminozuren } & \multirow[t]{2}{*}{ P-waarde } \\
\hline & Niet & Wel & & Niet & Wel & \\
\hline 4 weken leeftijd, aantal dieren: & 345 & 355 & & 360 & 340 & \\
\hline - \% bijtsporen & $27,0^{x}$ & $21,4^{y}$ & 0,07 & 22,5 & 25,9 & 0,35 \\
\hline - \% zichtbare wond & $8,7^{\mathrm{a}}$ & $14,6^{b}$ & 0,02 & 11,9 & 11,5 & 0,90 \\
\hline - \% geen beschadiging & 69,7 & 75,1 & 0,19 & $75,8^{x}$ & $69,2^{y}$ & 0,08 \\
\hline - \% bijtsporen & 13,3 & 9,6 & 0,15 & 9,8 & 13,0 & 0,21 \\
\hline - \% zichtbare wond & 17,0 & 15,3 & 0,65 & 14,4 & 17,8 & 0,36 \\
\hline 14 weken leeftijd, aantal dieren: & 258 & 258 & & 250 & 266 & \\
\hline 18 weken leeftijd, aantal dieren: & 252 & 256 & & 245 & 263 & \\
\hline - \% geen beschadiging ${ }^{1}$ & $54,4^{x}$ & $62,5^{y}$ & 0,08 & $53,5^{a}$ & $63,1^{b}$ & 0,04 \\
\hline - \% bijtsporen & $15,5^{x}$ & $10,2^{y}$ & 0,08 & 15,9 & 9,9 & 0,11 \\
\hline - \% zichtbare wond & 30,2 & 27,3 & 0,60 & 30,6 & 27,0 & 0,33 \\
\hline Voor afleveren, aantal dieren: & 249 & 253 & & 242 & 260 & \\
\hline - \% geen beschadiging & 81,9 & 79,1 & 0,29 & $75,2^{a}$ & $85,4^{b}$ & 0,005 \\
\hline - \% bijtsporen & 0,8 & 1,2 & 0,69 & 0,8 & 1,1 & 0,81 \\
\hline - \% zichtbare wond & 17,3 & 19,7 & 0,33 & $24,0^{\mathrm{a}}$ & $13,5^{\mathrm{b}}$ & 0,004 \\
\hline
\end{tabular}

Uit tabel 10 blijkt dat het percentage dieren zonder staartbeschadiging op 4 en 9 weken leeftijd en daags voor afleveren vergelijkbaar was bij wel of geen extra vezels in het voer. Op 14 en 18 weken leeftijd was het percentage dieren zonder staartbeschadiging hoger bij extra vezels in het voer. Het percentage dieren met bijtsporen was op 4 en 18 weken leeftijd lager bij extra vezels in het voer. Het percentage dieren met een zichtbare wond op de staart was op 4 weken leeftijd hoger en op 14 weken leeftijd lager bij extra vezels in het voer.

Op 4 en 14 weken leeftijd was het percentage dieren zonder staartbeschadiging vergelijkbaar bij wel of geen extra aminozuren in het voer. Op 9 weken leeftijd was het percentage dieren zonder staartbeschadiging lager en op 18 weken leeftijd en daags voor afleveren hoger bij extra aminozuren in het voer. Op 18 weken leeftijd was er een interactie tussen extra vezels en extra aminozuren in het voer. Het percentage dieren zonder staartbeschadiging was lager in de controlegroep dan in de andere drie proefbehandelingen (zie bijlage 11). Het percentage dieren met een zichtbare wond op de staart was op 14 weken leeftijd hoger en daags voor afleveren lager bij extra aminozuren in het voer.

Het percentage dieren zonder staartbeschadiging was het hoogst de dag voor afleveren en het laagst op 14 en 18 weken leeftijd.

In tabel 11 is het percentage dieren met een intacte staartlengte op 4, 9, 14 en 18 weken leeftijd en daags voor afleveren weergegeven voor de hoofdeffecten wel/geen extra vezels en wel/geen extra aminozuren. De resultaten per proefbehandeling zijn weergegeven in bijlage 11. 
Tabel 11 Percentage dieren met een intacte staartlengte op 4, 9, 14 en 18 weken leeftijd en daags voor afleveren die wel of geen extra vezels en wel of geen extra aminozuren in het voer kregen

\begin{tabular}{lcccccc} 
& \multicolumn{2}{c}{ Extra vezels } & P-waarde & \multicolumn{2}{c}{ Extra aminozuren } \\
& Niet & Wel & & & Niet & Wel \\
\hline 4 weken leeftijd & 98,6 & 98,9 & 0,45 & 99,2 & 98,2 & 0,43 \\
\hline 9 weken leeftijd & 96,3 & 95,4 & 0,59 & $97,3^{x}$ & $94,6^{y}$ & 0,10 \\
\hline 14 weken leeftijd & $87,6^{a}$ & $96,5^{b}$ & 0,003 & $95,2^{x}$ & $89,1^{y}$ & 0,05 \\
\hline 18 weken leeftijd & $75,0^{a}$ & $84,4^{b}$ & 0,02 & $83,3^{x}$ & $76,4^{y}$ & 0,08 \\
\hline Dag voor afleveren & $71,0^{a}$ & $82,3^{b}$ & 0,008 & $80,6^{x}$ & $73,1^{y}$ & 0,08 \\
\hline
\end{tabular}

${ }^{a, b}$ Gemiddelden met een verschillende letter binnen een rij zijn verschillend $(p<0,05)$; ${ }^{x, y}$ Gemiddelden met een verschillende letter binnen een

rij tenderen naar verschillend $(p<0,10)$

Uit tabel 11 blijkt dat het percentage dieren met een intacte staartlengte (er mist geen deel van de staart) op 4 en 9 weken leeftijd vergelijkbaar was bij wel of geen extra vezels in het voer. Op 14 en 18 weken leeftijd en daags voor afleveren was het percentage dieren met een intacte staartlengte hoger bij extra vezels in het voer.

Op 9, 14 en 18 weken leeftijd en daags voor afleveren was er een tendens tot een lager percentage dieren met een intacte staartlengte bij extra aminozuren in het voer.

In alle behandelingen daalde het percentage dieren met een intacte staart met het ouder worden van de dieren.

In tabel 12 is het percentage dieren met oorbeschadigingen op 4, 9, 14 en 18 weken leeftijd en daags voor afleveren weergegeven voor de hoofdeffecten wel/geen extra vezels en wel/geen extra aminozuren. De resultaten per proefbehandeling zijn weergegeven in bijlage 11.

Tabel 12 Percentage dieren met oorbeschadigingen op 4, 9, 14 en 18 weken leeftijd en daags voor afleveren die wel of geen extra vezels en wel of geen extra aminozuren in het voer kregen

\begin{tabular}{lcccccc} 
& \multicolumn{2}{c}{ Extra vezels } & P-waarde & \multicolumn{2}{c}{ Extra aminozuren } \\
& Niet & Wel & & \multicolumn{2}{c}{ Niet } & Wel \\
\hline 4 weken leeftijd & 14,2 & 11,0 & 0,13 & $14,1^{x}$ & $10,9^{y}$ & 0,10 \\
\hline 9 weken leeftijd & 19,2 & 14,9 & 0,26 & 19,5 & 14,9 & 0,18 \\
\hline 14 weken leeftijd & 2,0 & 2,3 & 0,47 & 2,8 & 1,5 & 0,24 \\
\hline 18 weken leeftijd & 9,1 & 9,4 & 0,87 & 8,1 & 10,3 & 0,38 \\
\hline Dag voor afleveren & 1,6 & 3,5 & 0,17 & 2,5 & 2,7 & 0,58 \\
\hline
\end{tabular}

${ }^{x, y}$ Gemiddelden met een verschillende letter binnen een rij tenderen naar verschillend $(p<0,10)$

Uit tabel 12 blijkt dat er op geen enkel meetmoment een effect was van extra vezels in het voer op het percentage dieren met oorbeschadigingen.

Op 4 weken leeftijd was er een tendens tot een lager percentage dieren met oorbeschadigingen bij extra aminozuren in het voer. Op de overige meetmomenten was er geen effect van extra aminozuren in het voer.

In alle behandelingen was het percentage dieren met oorbeschadigingen het hoogste op 9 weken leeftijd.

In tabel 13 is het percentage dieren met flankbeschadigingen op 4, 9, 14 en 18 weken leeftijd en daags voor afleveren weergegeven voor de hoofdeffecten wel/geen extra vezels en wel/geen extra aminozuren. De resultaten per proefbehandeling zijn weergegeven in bijlage 11. 

afleveren die wel of geen extra vezels en wel of geen extra aminozuren in het voer kregen

\begin{tabular}{lcccccc} 
& \multicolumn{2}{c}{ Extra vezels } & P-waarde & \multicolumn{2}{c}{ Extra aminozuren } \\
& Niet & Wel & & & Niet & Wel \\
\hline 4 weken leeftijd & 0 & 0,3 & 0,99 & 0,3 & 0 \\
\hline 9 weken leeftijd & 0,4 & 0 & 0,99 & 0 & 0,4 & 0,97 \\
\hline 14 weken leeftijd & 1,6 & 0,8 & 0,98 & 2,0 & 0,4 & 0,98 \\
\hline 18 weken leeftijd & 3,2 & 2,3 & 0,76 & 2,4 & 3,1 \\
\hline Dag voor afleveren & 0,8 & 0,8 & 0,99 & 0,4 & 1,2 & 0,86 \\
\hline
\end{tabular}

Uit tabel 13 blijkt dat er geen effect was van extra vezels of van extra aminozuren in het voer op het percentage dieren met flankbeschadigingen. Flankbeschadigingen zijn weinig voorgekomen tijdens het onderzoek.

\subsection{Gedragswaarnemingen}

\subsubsection{Biggenopfokperiode}

In tabel 14 zijn het aantal keer staartbijten (kauwen aan of bijten in de staart van een hokgenoot), oorbijten (kauwen aan of bijten in het oor van een hokgenoot) en anders bijten (kauwen aan of bijten in elk willekeurig lichaamsdeel, behalve staart of oor) bij biggen op 7 weken leeftijd weergegeven voor de hoofdeffecten wel/geen extra vezels en wel/geen extra aminozuren. De resultaten per proefbehandeling zijn weergegeven in bijlage 12 .

Tabel 14 Aantal keren bijten per hok gedurende 8 keer 10 minuten waarnemen bij biggen op 7 weken leeftijd die wel of geen extra vezels en wel of geen extra aminozuren in het voer kregen

\begin{tabular}{|c|c|c|c|c|c|c|}
\hline & \multicolumn{2}{|c|}{ Extra vezels } & P-waarde & \multicolumn{2}{|c|}{ Extra aminozuren } & P-waarde \\
\hline Aantal hokken & 24 & 24 & & 24 & 24 & \\
\hline Staartbijten & 10,4 & 11,4 & 0,56 & 10,4 & 11,5 & 0,54 \\
\hline Oorbijten & 26,7 & 23,1 & 0,14 & 22,5 & 27,2 & 0,74 \\
\hline
\end{tabular}

${ }^{1}$ Significante interactie voor anders bijten $(42,0,22,5,26,5$ en 32,3 keer voor behandeling $1 \mathrm{t} / \mathrm{m} 4)$

Uit tabel 14 blijkt dat er geen effect was van extra vezels of van extra aminozuren in het voer op het aantal keren staartbijten, oorbijten en anders bijten per hok. Wel was er voor het kenmerk anders bijten een interactie tussen extra vezels en extra aminozuren in het voer. Het aantal keren anders bijten was het laagst bij de biggen die het controle voer met extra aminozuren of het vezelrijke voer kregen en het hoogst bij de biggen die het controlevoer kregen (zie bijlage 12).

Enkele dagen na het uitvoeren van de gedragswaarnemingen is één hok uit het onderzoek genomen vanwege ernstig vechten. Er waren enkele dieren in dat hok, die continue het gevecht aangingen met de andere dieren in het hok, waardoor een deel van de dieren wonden aan de nek hadden. Het hok is wel meegenomen in de resultaten van de gedragswaarnemingen zoals beschreven in tabel 14.

\subsubsection{Vleesvarkensfase}

In tabel 15 zijn het aantal keer staartbijten, oorbijten en anders bijten bij vleesvarkens op 21 weken leeftijd weergegeven voor de hoofdeffecten wel/geen extra vezels en wel/geen extra aminozuren. De resultaten per proefbehandeling zijn weergegeven in bijlage 12 . 
Tabel 15 Aantal keren bijten per hok gedurende 8 keer 10 minuten waarnemen bij vleesvarkens op 21 weken leeftijd die wel of geen extra vezels en wel of geen extra aminozuren in het voer kregen

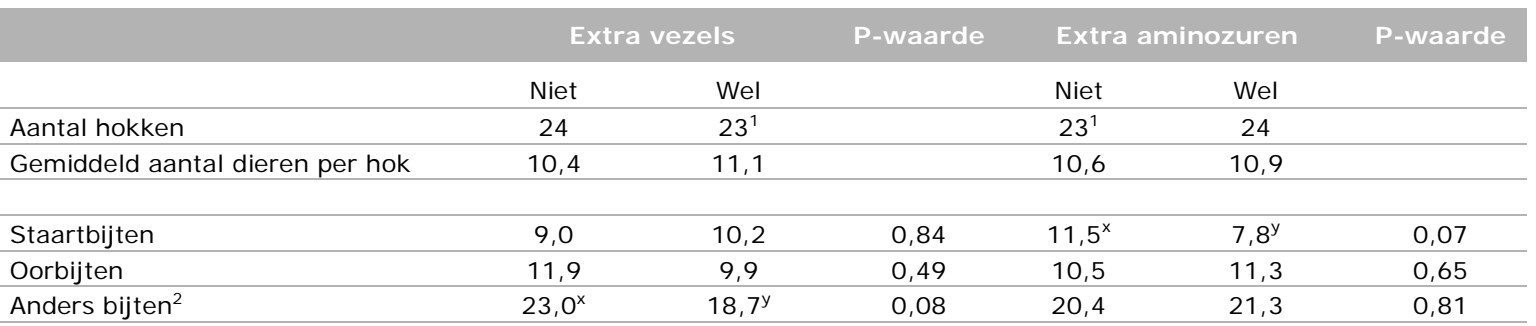

1 Eén hok is voortijdig uit het onderzoek genomen vanwege ernstig vechten; ${ }^{2}$ Significante interactie voor anders bijten (26,3, 14,1, 19,7 en

23,0 keer voor behandeling $1 \mathrm{t} / \mathrm{m} 4)$; ${ }^{x, y}$ Gemiddelden met een verschillende letter binnen een rij tenderen naar verschillend $(p<0,10)$

Uit tabel 15 blijkt dat er geen effect was van extra vezels in het voer op het aantal keren staartbijten en oorbijten. Voor het kenmerk anders bijten was er een interactie tussen extra vezels en extra aminozuren in het voer. Het aantal keer anders bijten was het laagst bij de vleesvarkens die het vezelrijke voer kregen en het hoogst bij de vleesvarkens die het controlevoer of het vezelrijke voer met extra aminozuren kregen (zie bijlage 12).

Het aantal keer staartbijten was lager bij de vleesvarkens die extra aminozuren in het voer kregen. Er was geen effect van extra aminozuren in het voer op het aantal keer oorbijten en anders bijten.

\subsection{Vangnet en verbruik hokverrijkingsmateriaal}

\section{Kraamstal}

Tijdens de zoogperiode zijn geen rode hokkaarten en vangnet wegens staart- of oorbijten ingezet. Tevens zijn geen oranje hokkaarten ingezet en zijn er geen dieren naar de noodopvang verplaatst. In elk kraamhok is één jute doek verbruikt.

Biggenopfokstal

$\underline{\text { Inzet rode hokkaart en vangnet: }}$

- In 11 van de 48 hokken (één hok controlevoer, vier hokken vezelrijk voer, vier hokken voer met extra aminozuren en twee hokken vezelrijk voer met extra aminozuren) zijn een rode hokkaart en vangnet ingezet gedurende 2 tot 19 dagen. In één hok is het vangnet ingezet op 4 dagen na spenen, in vier hokken in de derde week na spenen, in drie hokken in de vierde week na spenen en in drie hokken in de vijfde week na spenen.

- Eén hok (hok met vezelrijk voer) met ingezet vangnet vanwege staartbijten is uit het onderzoek genomen vanwege ernstig vechten van de dieren.

- Bij ca. 4\% van de gespeende biggen is een staart- of oorwond geconstateerd en is een dierkaart ingevuld. Het aantal dieren met een bijtwond aan de staart in de 10 hokken met vangnet was als volgt: in zes hokken één dier, in twee hokken drie dieren en in één hok zeven dieren. Daarnaast was er één hok met een dier met een bijtwond aan het oor.

- $\quad$ Bij het inzetten van het vangnet is gekeken of er een dader aan te wijzen was en zijn de waterafgifte van de drinknippels in de betreffende hokken en de afdelingstemperatuur vastgelegd. In twee hokken was er een mogelijke dader. Deze dieren zijn niet uit het hok gehaald omdat het niet volledig zeker was of het de daders waren. In vier van de 11 hokken met rode hokkaart was de waterafgifte van de drinknippel minder dan de gewenste minimum waterafgifte van 0,7 liter per minuut. De temperatuur in de afdelingen bij inzet van een rode hokkaart was aan de hoge kant (23,5 tot 28 graden in de derde week na spenen en 26 tot 27 graden in de vierde en vijfde week na spenen). 


\section{Effect vangnet:}

In één hok met controlevoer is 23 dagen na spenen een vangnet ingezet. Drie dieren in dit hok hadden een wond aan de staart en zijn via een dierkaart intensief gevolgd. Bij alle drie de dieren was sprake van een grote wond, waarbij de gehele punt beschadigd was. Vier dagen na het constateren van de verwonding was er bij alle staarten sprake van korstvorming. Na 8 dagen was de situatie zodanig rustig dat het vangnet uit het hok is gehaald.

- In de twee hokken (in een derde hok was sprake van een verwonding aan het oor, in het vierde hok zijn de dieren vanwege agressief bijten voortijdig uit de proef genomen) met vezelrijk voer waarin staartverwondingen zijn waargenomen hadden in totaal 2 dieren een staartwond. In één hok werd één dier met een staartwond gezien op dag 19 na spenen, in het andere hok was dit één dier op dag 34 na spenen. Het betrof in beide gevallen een kleine wond waarbij een deel van de punt beschadigd was. Bij beide dieren was de wond binnen enkele dagen voldoende hersteld en kon gestopt worden met het inzetten van het vangnet.

- In de vier hokken met extra aminozuren hadden in totaal vier dieren een staartwond. De wonden werden waargenomen op respectievelijk 21, 27 en 33 ( 2 dieren) dagen na spenen. Bij twee dieren was sprake van een kleine wond, bij één dier van een grote wond en bij één dier was de staartlengte niet meer intact. Bij alle dieren was de wond na ongeveer een week voldoende hersteld en kon gestopt worden met het inzetten van het vangnet.

- In de twee hokken met vezelrijk voer met extra aminozuren hadden in totaal 10 dieren ( 3 dieren in het ene en 7 in het andere hok) een staartwond. Bij één dier werd de beschadiging 16 dagen na spenen waargenomen, bij de andere dieren was dit 20 tot 24 dagen na spenen. $\mathrm{Bij}$ vier dieren was sprake van een kleine wond, bij vier dieren van een grote wond en bij twee dieren was de staartlengte niet meer intact. Het duurde ongeveer een week ( 7 dieren) tot bijna drie weken ( 3 dieren) totdat de wond voldoende hersteld was en gestopt kon worden met het inzetten van het vangnet.

\section{Verbruik van vangnetmaterialen:}

- $\quad$ Eén hok met controlevoer: 0,50 m touw en 1,0 kg luzerne ( 5 scheppen luzerne (een schep is 200 gram));

- Twee hokken met vezelrijk voer: gemiddeld 0,50 m touw en 0,45 kg luzerne (2,25 scheppen) per hok;

- Vier hokken met extra aminozuren: gemiddeld 0,75 m touw en 0,60 kg (3 scheppen) per hok;

- Twee hokken vezelrijk voer met extra aminozuren: gemiddeld 1,00 m touw en 1,65 kg luzerne $(8,25$ scheppen) per hok.

Het verbruik van luzerne was het hoogst bij de biggen die vezelrijk voer met extra aminozuren kregen omdat het vangnet langer ingezet moest worden.

\section{Inzet oranje hokkaarten:}

Naast de 11 rode hokkaarten is in zeven hokken (twee hokken controlevoer, één hok vezelrijk voer, twee hokken met extra aminozuren en twee hokken vezelrijk voer met extra aminozuren) een oranje hokkaart ingezet gedurende 2 tot 13 dagen, als teken dat de dieren in een hok extra aandacht behoefden op basis van staarthouding, gedrag en/of (staart)verwondingen in het verleden. Bij vijf van de zeven hokken is alleen een oranje hokkaart ingezet. Bij twee hokken is een oranje hokkaart ingezet na het weghalen van de rode hokkaart. In twee hokken is de oranje hokkaart ingezet in de tweede week na spenen, in één hok in de derde week na spenen en in vier hokken in de vijfde week na spenen. In twee van de zeven hokken met oranje hokkaart was de waterafgifte van de drinknippel minder dan de gewenste minimum waterafgifte van 0,7 liter per minuut. De temperatuur in de afdelingen bij inzet van een oranje hokkaart was aan de hoge kant (ruim 27 graden).

\section{Verbruik basis hokverrijkingsmateriaal:}

Als basishokverrijking werden jute doeken aan de gespeende biggen verstrekt. Het gemiddeld aantal verbruikte jute doeken per hok was 5,3 bij het controlevoer, 4,4 bij het vezelrijke voer, 6,3 bij het voer met extra aminozuren en 4,8 bij het vezelrijke voer met extra aminozuren. Dit is respectievelijk 5,8 en 4,6 jute doeken bij geen en wel extra vezels in het voer en respectievelijk 4,8 en 5,5 jute doeken bij geen en wel extra aminozuren in het voer. 
Vleesvarkensstal

Inzet rode kaart en vangnet en inzet oranje kaart:

In tabel 16 is het aantal hokken met een rode kaart en vangnet, de duur van het vangnet, het aantal dieren met een dierkaart, de grootte van de staartwond, duur van herstel van de wond (korst op de wond) en aantal hokken met een oranje kaart weergegeven per proefbehandeling.

Tabel 16 Aantal hokken met een rode kaart en vangnet, duur van het vangnet, aantal dieren met een dierkaart, grootte van de staartwond, duur van herstel van de wond (korst op de wond) en aantal hokken met oranje kaart bij vleesvarkens die controle voer, vezelrijk voer, voer met extra aminozuren of vezelrijk voer met extra aminozuren verstrekt kregen

\begin{tabular}{|c|c|c|c|c|}
\hline & Controle voer & $\begin{array}{c}\text { Vezelrijk } \\
\text { voer }\end{array}$ & $\begin{array}{l}\text { Voer met extra } \\
\text { aminozuren }\end{array}$ & $\begin{array}{l}\text { Vezelrijk voer met } \\
\text { extra aminozuren }\end{array}$ \\
\hline Aantal hokken met vangnet en rode kaart & 6 & 6 & 8 & 7 \\
\hline - waarvan vangnet 2 keer ingezet & 3 & 2 & $1^{1}$ & 0 \\
\hline $1^{\text {ste }}$ keer inzetten vangnet (wk na opleg) & 1 tot 5 & 3 tot 11 & 1 tot 11 & 1 tot 12 \\
\hline Duur inzet vangnet (wk) & 1 tot 3 & 1 tot 5 & 1 tot 5 & 1 tot 4 \\
\hline Aantal dieren met dierkaart & 19 & 11 & 34 & 13 \\
\hline \multicolumn{5}{|l|}{ Waarvan: } \\
\hline - kleine staartwond & 9 & 3 & 16 & 4 \\
\hline - grote staartwond & 7 & 6 & 17 & 8 \\
\hline - staartlengte niet meer intact & 3 & 1 & 1 & 1 \\
\hline - flankwond & 0 & 1 & 0 & 0 \\
\hline Aantal dieren met dierkaart per hok & 2 tot 4 & 1 tot 4 & 1 tot 9 & 1 tot 4 \\
\hline Aantal dieren met korst op staartwond na $3 \mathrm{~d}$ & 18 & 9 & 32 & 13 \\
\hline Aantal hokken met oranje kaart & 8 & 6 & 9 & 7 \\
\hline - alleen oranje kaart & 2 & 0 & 1 & 0 \\
\hline - voorafgaand aan rode kaart & 1 & 3 & 4 & 3 \\
\hline - volgend op rode kaart & 5 & 3 & 4 & 4 \\
\hline Inzet oranje kaart (wk na opleg) & 1 tot 10 & 1 tot 12 & 1 tot 12 & 2 tot 11 \\
\hline Duur inzet oranje kaart (wk) & 1 tot 6 & 1 tot 4 & 1 tot 4 & 1 tot 3 \\
\hline
\end{tabular}

${ }^{1}$ Vangnet is drie keer ingezet in dit hok (bij opleg, op dag 34 na opleg en op dag 95 na opleg).

- In 27 van de 47 hokken is het vangnet ingezet. Bij drie (één hok voer met extra aminozuren en twee hokken vezelrijkvoer met extra aminozuren) van de 27 hokken werd het vangnet gecontinueerd vanuit de biggenopfokstal omdat er in die hokken dieren waren met een staartwond bij opleg in de vleesvarkensstal. Er was veel variatie in het moment waarop het nodig was een vangnet in te zetten: dit varieerde van binnen een week na opleg tot 12 weken na opleg. Ook de duur van de periode dat een vangnet werd ingezet varieerde tussen de hokken, van ongeveer een week tot vijf weken.

- $\quad$ Bij 77 vleesvarkens (is ca. 15\% van de vleesvarkens) is gedurende de vleesvarkensfase een staartwond geconstateerd en is een dierkaart ingevuld.

- Bij het inzetten van het vangnet is gekeken of er een dader aan te wijzen was en zijn de waterafgifte van de drinknippels in de betreffende hokken en de afdelingstemperatuur vastgelegd. In twee hokken was er een dader aan te wijzen en deze zijn uit het hok gehaald. In zes van de 27 hokken met een rode hokkaart was de waterafgifte van de drinknippel minder dan 1,5 liter per minuut en één hok was de waterafgifte minder dan 1,0 liter per minuut. De temperatuur in de afdeling bij constatering van bijtschade was bij de meeste hokken tussen de 22 en 25 graden. I

- In acht van de 12 hokken met voer met extra aminozuren is een vangnet ingezet. In vier hokken hadden maximaal 3 dieren een staartwond; in de overige vier hokken waren dit respectievelijk 4, 5, 7 en 9 dieren.

- In 30 hokken zijn éénmalig of meerdere keren oranje hokkaarten ingezet, als teken dat de dieren in een hok extra aandacht behoefden op basis van staarthouding, gedrag en/of (staart) verwondingen in het verleden. In vier hokken was de waterafgifte van de drinknippel minder dan 1,5 liter per minuut. De temperatuur in de afdeling bij inzet van een oranje hokkaart lag tussen de 23 en 25,5 graden. In drie van de 30 hokken is alleen een oranje 
hokkaart ingezet, in 11 hokken is de oranje kaart ingezet voorafgaand aan een rode hokkaart en in 16 hokken is de oranje hokkaart ingezet na het weghalen van de rode hokkaart.

Verbruik van vangnetmaterialen:

- Zes hokken met controlevoer: gemiddeld 1,00 m touw en 16,8 kg luzerne per hok;

- Zes hokken met vezelrijk voer: gemiddeld 0,50 m touw en 15,3 kg luzerne per hok;

- Acht hokken met extra aminozuren: gemiddeld 1,30 m touw en 19,2 kg luzerne per hok;

- Zeven hokken vezelrijk voer met extra aminozuren: gemiddeld 1,00 m touw en 15,2 kg luzerne per hok.

Het verbruik van luzerne was lager bij extra vezels in het voer.

Verbruik basis hokverrijkingsmateriaal:

Als basishokverrijking werden jute zakken aan de vleesvarkens verstrekt. Het gemiddeld aantal verbruikte jute zakken per hok was 8,6 bij het controlevoer, 8,5 bij het vezelrijke voer, 12,2 bij het voer met extra aminozuren en 10,6 bij het vezelrijke voer met extra aminozuren. Dit is respectievelijk 10,4 en 9,6 jute zakken bij geen en wel extra vezels in het voer en respectievelijk 8,6 en 11,4 jute zakken bij geen en wel extra aminozuren in het voer.

\subsection{Financiële resultaten}

In de economische berekening zijn de verschillen in technische resultaten, slachtkwaliteit, voerkosten en kosten voor uitval en veterinaire behandelingen meegenomen van de dieren die controle voer, vezelrijk voer, voer met extra aminozuren of vezelrijk voer met extra aminozuren kregen. Daarnaast is een inschatting gemaakt van de kosten van de verbruikte materialen (jute zakken/doeken, touw en luzerne) in de verschillende proefbehandelingen.

De volgende uitgangspunten zijn gehanteerd in de economische berekening (normen zijn gebaseerd op KWIN 2016-2017):

\begin{tabular}{llcrr} 
& Controle voer & Vezelrijk voer & Voer met extra & Vezelrijk voer met \\
& & & aminozuren & $+x$ aminozuren \\
Speenvoer & Basis & $+€ 0,95$ & $+€ 1,40$ & $+€ 2,20$ \\
\hline Opfokkorrel & Basis & $+€ 1,95$ & $+€ 1,30$ & $+€ 3,30$ \\
\hline Startvoer & Basis & $+€ 0,85$ & $+€ 1,55$ & $+€ 2,40$ \\
\hline Tussenvoer & Basis & $+€ 1,10$ & $+€ 1,40$ & $+€ 2,50$ \\
\hline Eindvoer & Basis & $+€ 1,25$ & $+€ 1,55$ & $+€ 2,85$
\end{tabular}

- Voerkosten (excl. BTW) per $100 \mathrm{~kg}$ (zie onderstaande tabel):

- Kosten van een uitgevallen (gestorven) dier:

Kosten van een uitgevallen gespeende big: $€ 25,25$; gerekend is met de werkelijke uitval. Kosten van een uitgevallen vleesvarken: $€ 75$; gerekend is met de werkelijke uitval.

- De kosten per behandeld dier zijn opgebouwd uit kosten voor de toegepaste middelen en kosten voor de arbeid. De kosten van de toegepaste middelen zijn berekend op $€ 0,09$ per $\mathrm{ml}$ (gebaseerd op de meest toegepaste middelen op VIC Sterksel). Gespeende biggen zijn veelal 3 opeenvolgende dagen behandeld met gemiddeld $2 \mathrm{ml}$ middel(en). Vleesvarkens zijn veelal 3 opeenvolgende dagen behandeld met gemiddeld $3 \mathrm{ml}$ middel(en). Uit eerder onderzoek (niet gepubliceerd) op het voormalig Proefstation voor de Varkenshouderij bleek dat de veterinaire behandeling van een gespeende big of vleesvarken gemiddeld 1,13 minuut kost. De arbeidskosten bedragen $€ 26,13$ per uur (Biggenprijzenschema 2016; loonkosten volgens CAO).

- Overige kosten: Dit betreft de kosten voor algemene gezondheidszorg, water, gas, elektra, strooisel en dergelijke. Deze zijn in de opfokperiode $€ 1,90$ per afgeleverde big en in de vleesvarkensfase $€$ 4,37 per afgeleverd vleesvarken. De kosten per afgeleverde big zijn als volgt berekend: algemene gezondheidskosten $€ 0,77$, kosten voor elektriciteit + water + verwarming $€ 0,92$ en overige kosten $€ 0,21$. De kosten per vleesvarken zijn als volgt opgebouwd: algemene gezondheidskosten $€ 1,04$, kosten voor elektriciteit + water + verwarming $€ 2,60$ en overige kosten $€ 0,73$. 
- $\quad$ Opbrengstprijs vleesbig: de biggenprijs is $€ 41,50$ bij 25 kg. Biggen lichter of zwaarder dan 25 $\mathrm{kg}$ brengen per $\mathrm{kg}$ afwijking $€ 0,70$ minder of meer op.

- Opbrengstprijs vleesvarken: volgens de uitbetalingssystematiek van VION Good Farming Welfare, januari 2015. De basisprijs, exclusief kortingen, toeslagen, heffingen en dergelijke, bedraagt $€ 1,39$. Het uitbetalingssysteem van VION is gebruikt om de kortingen en toeslagen voor vleespercentage, spier- en spekdikte te berekenen. Daarnaast is de gewichtskorting berekend.

- $\quad$ Kosten jute zak: $€ 0,50$ per stuk

Kosten jute doek: $€ 0,45$ per stuk

Kosten touw: $€ 0,34$ per meter

Kosten luzerne: $€ 10,60$ per baal van $20 \mathrm{~kg}$

Het financiële resultaat per afgeleverde big is weergegeven in tabel 17.

Tabel 17 Financieel resultaat (in € per afgeleverd big) van biggen die vanaf circa 2,5 weken leeftijd controle voer, vezelrijk voer, voer met extra aminozuren of vezelrijk voer met extra aminozuren verstrekt kregen; het verschil is weergegeven ten opzichte van het controle voer $(+=$ hoger; - = lager $)$

\begin{tabular}{|c|c|c|c|c|c|c|}
\hline & Controle voer & Vezelrijk voer & $\begin{array}{l}\text { Voer met extra } \\
\text { aminozuren }\end{array}$ & $\begin{array}{l}\text { Vezelrijk voer met } \\
\text { extra aminozuren }\end{array}$ & SEM ${ }^{1}$ & P-waarde \\
\hline Opbrengst & $-{ }^{a}$ & $+0,11^{a}$ & $-0,83^{b}$ & $-1,17^{b}$ & 0,28 & 0,005 \\
\hline Voerkosten & $-{ }^{a}$ & $+0,37^{c}$ & $+0,27^{b}$ & $+0,63^{d}$ & 0,01 & $<0,001$ \\
\hline Uitvalkosten & - & $+0,50$ & $-0,18$ & $-1,06$ & & \\
\hline $\begin{array}{l}\text { Kosten veterinaire } \\
\text { behandelingen }\end{array}$ & - & $-0,04$ & $-0,10$ & $-0,14$ & & \\
\hline Overige kosten ${ }^{2}$ & - & $+0,00$ & $+0,00$ & $+0,00$ & & \\
\hline Kosten jute doeken & - & $-0,02$ & $+0,04$ & $-0,03$ & & \\
\hline Kosten touw + luzerne & - & $-0,02$ & $-0,01$ & $+0,04$ & & \\
\hline Totale kosten & $-{ }^{a}$ & $+0,79^{b}$ & $+0,02^{a}$ & $-0,56^{c}$ & 0,02 & $<0,001$ \\
\hline Opbrengst - kosten & $-{ }^{a}$ & $-0,68^{a b}$ & $-0,85^{b}$ & $-0,61^{a b}$ & 0,29 & 0,016 \\
\hline
\end{tabular}

${ }^{1} \mathrm{SEM}=$ gepoolde standard error van het gemiddelde; ${ }^{2}$ overige kosten: kosten voor gezondheidszorg, elektriciteit, water, verwarming en overig;

a,b Gemiddelden met een verschillende letter binnen een rij zijn verschillend $(p<0,05)$

Uit tabel 17 blijkt dat het financiële resultaat per afgeleverde big significant hoger was bij de biggen die het controlevoer kregen dan bij de biggen die het controlevoer met extra aminozuren kregen. Dit is $\mathrm{m}$. n. het gevolg van de hogere opbrengst en de lagere voerkosten per afgeleverde big van de biggen op het controlevoer. Het financiële resultaat per afgeleverde big van de biggen die het vezelrijke voer of het vezelrijke voer met extra aminozuren kregen zat hier tussen in.

Het financiële resultaat per afgeleverd vleesvarken is weergegeven in tabel 18.

Tabel 18 Financieel resultaat (in € per afgeleverd vleesvarken) van vleesvarkens die controle voer, vezelrijk voer, voer met extra aminozuren of vezelrijk voer met extra aminozuren verstrekt kregen; het verschil is weergegeven ten opzichte van het controlevoer ( $+=$ hoger; - = lager)

\begin{tabular}{|c|c|c|c|c|c|c|}
\hline & Controle voer & Vezelrijk voer & $\begin{array}{l}\text { Voer met extra } \\
\text { aminozuren }\end{array}$ & $\begin{array}{l}\text { Vezelrijk voer met } \\
\text { extra aminozuren }\end{array}$ & SEM $^{1}$ & P-waarde \\
\hline Opbrengst & - & $-2,65$ & $-2,51$ & $-3,82$ & 1,47 & 0,31 \\
\hline Kosten aankoop big & - & $+0,19$ & $-0,83$ & $-0,44$ & 0,32 & 0,13 \\
\hline Voerkosten & $-{ }^{a}$ & $+2,67^{b}$ & $+3,67^{c}$ & $+6,25^{d}$ & 0,05 & $<0,001$ \\
\hline Uitvalkosten & - & $+0,83$ & $+2,70$ & $-1,20$ & & \\
\hline $\begin{array}{l}\text { Kosten veterinaire } \\
\text { behandelingen }\end{array}$ & - & $-0,01$ & $+0,17$ & $+0,10$ & & \\
\hline Overige kosten & - & $+0,00$ & $+0,00$ & $+0,00$ & & \\
\hline Kosten jute zakken & - & $+0,00$ & $+0,20$ & $+0,05$ & & \\
\hline Kosten touw + luzerne & - & $-0,06$ & $+0,18$ & $-0,15$ & & \\
\hline Totale kosten & $-{ }^{a}$ & $+3,62^{b}$ & $+6,09^{c}$ & $+4,61^{d}$ & 0,34 & $<0,001$ \\
\hline Saldo ${ }^{2}$ & $-{ }^{a}$ & $-6,27^{b}$ & $-8,60^{b}$ & $-8,43^{b}$ & 1,51 & $<0,001$ \\
\hline
\end{tabular}

${ }^{1}$ SEM = gepoolde standard error van het gemiddelde; ${ }^{2}$ saldo = opbrengst minus kosten; ${ }^{a, b, c, d}$ Gemiddelden met een verschillende letter binnen een rij zijn verschillend $(p<0,05)$

Uit tabel 18 blijkt dat het saldo per afgeleverd vleesvarken het hoogst was bij de vleesvarkens die het controlevoer kregen. Dit komt m.n. door de hogere opbrengst en de lagere voerkosten per afgeleverd 
vleesvarken. Het saldo per afgeleverd vleesvarkens verschilde niet significant tussen de vleesvarkens die het vezelrijke voer, het voer met extra aminozuren of het vezelrijke voer met extra aminozuren kregen.

Tijdens het onderzoek zijn 10 dieren ( 2 daders en 8 slachtoffers) naar de noodopvang verplaatst. Eén van de twee daders is als zoekbeer ingezet op VIC Sterksel. De overige negen dieren zijn op slachtleeftijd naar het slachthuis geleverd en hadden een vergelijkbare groei als de andere dieren in het onderzoek. Het verbruik van vangnetmaterialen en eventuele extra arbeid voor de dieren in de noodopvang is niet geregistreerd. 


\section{$4 \quad$ Discussie}

Onderzocht is of bijtgedrag (staart-, oor- en flankbijten) en bijtschade (staart- en oorschade) bij dieren met intacte (niet gecoupeerde) staart verminderd kunnen worden door de dieren vanaf enkele dagen na geboorte tot afleveren naar het slachthuis voer met extra vezels (verzadigend voer) en/of voer met extra aminozuren (tryptofaan, threonine en methionine) te geven. Daarnaast is nagegaan wat het effect is van extra vezels en extra aminozuren in het voer op de technische en financiële resultaten van gespeende biggen en vleesvarkens.

\subsection{Bijtgedrag en bijtschade}

Op een leeftijd van 4 weken (bij spenen), 9 weken (bij opleg in de vleesvarkensstal), 14 weken, 18 weken en daags voor afleveren zijn alle individuele dieren beoordeeld op staart- en oorbeschadigingen en is beoordeeld of de staartlengte wel of niet intact was.

\section{Verloop van staart- en oorschade in de tijd}

In figuur 1 is de verdeling van de staartschadescores (geen staartbeschadiging, bijtsporen en zichtbare wond) van alle dieren in het onderzoek (dus over proefbehandelingen heen) op de vijf meetmomenten weergegeven.

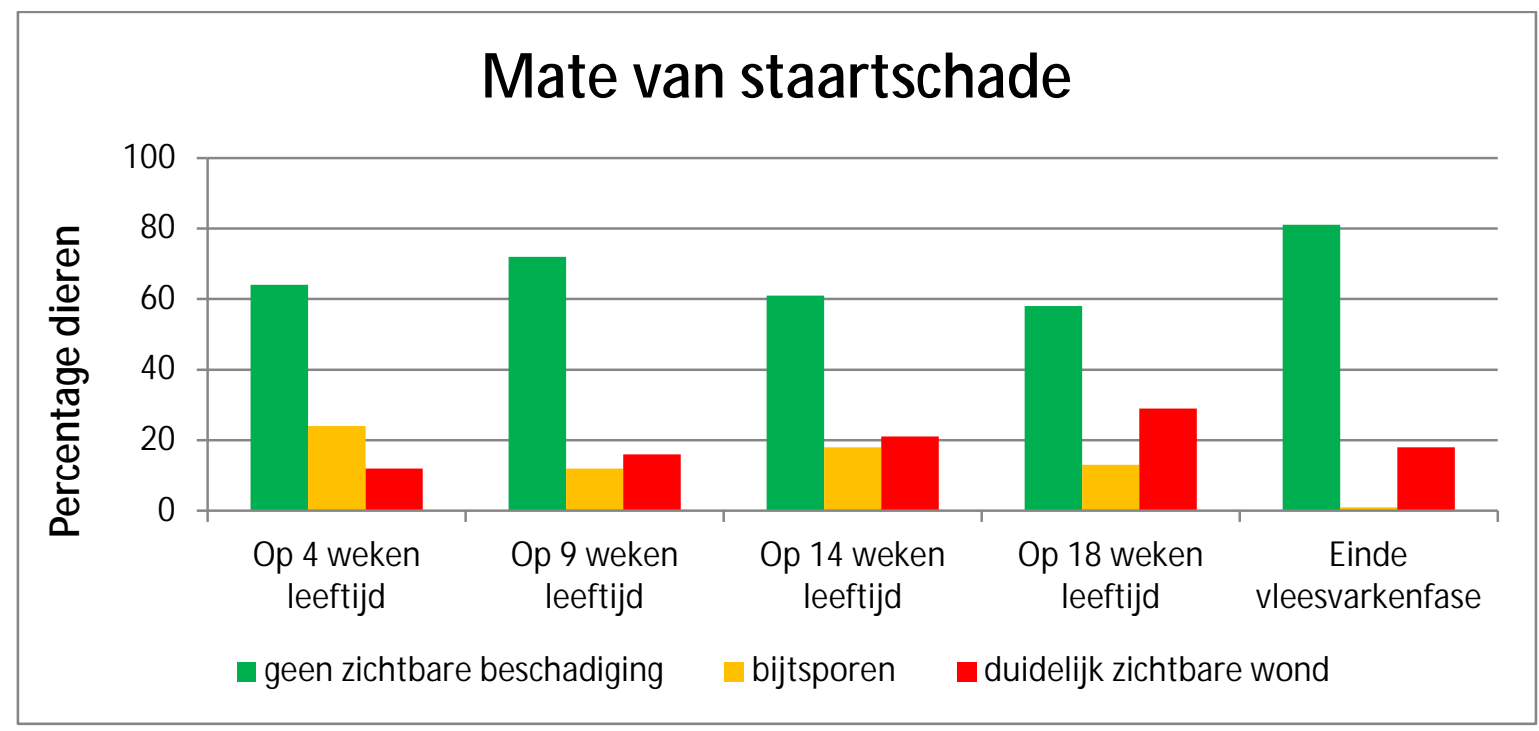

Figuur 1 Mate van staartschade (gemiddeld over alle dieren in het onderzoek)

Uit figuur 1 blijkt dat bij spenen op 4 weken leeftijd gemiddeld $64 \%$ van de biggen geen staartbeschadiging had, $24 \%$ had bijtsporen en $12 \%$ had een zichtbare wond. In het demonstratieproject (Van der Peet et al., 2016) had op 4 weken leeftijd circa $44 \%$ van de biggen geen staartbeschadiging, 39\% had bijtsporen en $17 \%$ had een zichtbare wond. In ons onderzoek is het percentage biggen met bijtsporen of een zichtbare wond op 4 weken leeftijd dus $20 \%$ lager dan in het demonstratieproject. Uit beide onderzoeken blijkt echter dat staartbijten al in de kraamstal voorkomt. Dit is ook bekend vanuit de wetenschappelijke literatuur (o.a. Ursinus et al., 2014).

Op 9 weken leeftijd had gemiddeld $72 \%$ van de dieren geen staartbeschadiging, $12 \%$ had bijtsporen en $16 \%$ had een zichtbare wond. Bij $4 \%$ van de gespeende biggen is tussen 4 en 9 weken leeftijd een staart- of oorwond geconstateerd en is een dierkaart ingevuld. Dit is dus lager dan de $16 \%$ met een zichtbare wond of 9 weken leeftijd. Op 9 weken leeftijd zijn de dieren allemaal individueel in de weegschaal gezet en zijn de staarten beoordeeld. Bij deze nauwkeurige inspectie worden wondjes 
gezien die bij beoordeling vanaf de voergang niet zichtbaar zijn. Met name kleine wondjes worden niet gezien bij beoordeling vanaf de voergang. In het demonstratieproject ( Van der Peet et al., 2016) had op 9 weken leeftijd $66 \%$ van de dieren geen staartbeschadiging, 18\% had bijtsporen en $16 \%$ had een zichtbare wond. In beide onderzoeken neemt het percentage dieren zonder staartbeschadiging toe van 4 tot 9 weken leeftijd. Het percentage dieren met een zichtbare wond blijft echter gelijk of neemt iets toe van 4 tot 9 weken leeftijd. In het onderzoek van Ursinus et al. (2014) nam het percentage dieren met een zichtbare wond ook iets toe van 4 tot 9 weken leeftijd.

Tijdens de vleesvarkensperiode daalde het percentage dieren zonder staartbeschadigingen naar $61 \%$ op 14 leeftijd en $58 \%$ op 18 weken leeftijd om vervolgens toe te nemen naar $81 \%$ de dag voor afleveren naar het slachthuis. Het percentage dieren met een zichtbare wond nam toe van 16, naar 21 en $29 \%$ op respectievelijk 9, 14 en 18 weken leeftijd om vervolgens te dalen naar $18 \%$ de dag voor afleveren. Het percentage dieren zonder staartbeschadigingen was gedurende het vleesvarkenstraject dus lager en het percentage dieren met een zichtbare wond hoger dan de dag voor afleveren. Aan het eind van het vleesvarkens periode zijn de staartschades mogelijk deels hersteld door inzet van het vangnet. Ook Ursinus et al. (2014) zagen dat het percentage opfokzeugen met een zichtbare wond toenam van 9 naar 13 weken leeftijd. Dit zagen ze echter niet als de dieren een jute zak ter beschikking hadden. In het demonstratieproject (Van der Peet et al., 2016) had 82\% van de dieren geen staartbeschadiging de dag voor afleveren en had $12 \%$ een duidelijk zichtbare wond. Dit komt overeen met de resultaten die wij gevonden hebben.

Het percentage dieren met een intacte staartlengte (er mist geen deel van de staart) daalde met het ouder worden van de dieren. Het daalde van 98, naar 96, 92, 80 en 77\% op respectievelijk 4, 9, 14 en 18 weken leeftijd en daags voor afleveren. Een niet intacte staart (deel van de staart is eraf) herstelt zich niet door inzet van het vangnet, het blijft altijd een niet intacte staart. Bij afleveren miste gemiddeld $23 \%$ van de dieren een deel van de staart.

Op 4 en 9 weken leeftijd had respectievelijk 13 en 17\% van de biggen een oorbeschadiging. Tijdens de vleesvarkensperiode was dit van 2, 9 en 3\% op respectievelijk 14 en 18 weken leeftijd en daags voor afleveren. Oorbeschadigingen kwamen, net als staartbeschadigingen, dus al voor in de kraamstal. Ze kwamen het meeste voor bij de gespeende biggen en in veel mindere mate bij de vleesvarkens. Ook uit de gedragswaarnemingen bleek dat oorbijten veel meer voorkwam op 7 weken leeftijd dan op 21 weken leeftijd ( 25 vs 11 keer per hok gedurende 8 keer 10 minuten waarnemen). Oorbeschadigingen kunnen het gevolg zijn van agressief gedrag (D'Eath, 2002). Bij spenen zijn de biggen uit verschillende tomen gemengd. Dit kan resulteren in agressief gedrag omdat de rangorde vastgesteld moet worden. Bij opleg in de vleesvarkensstal zijn ze niet opnieuw gemengd en hoefde de rangorde niet opnieuw vastgesteld te worden. Agressief gedrag is niet gemeten tijdens het onderzoek maar mogelijk vertoonden de gespeende biggen meer agressief gedrag dan de vleesvarkens en verklaart dit het hogere percentage biggen met oorbeschadigingen.

\section{Effect extra vezels}

Op 4 en 9 weken leeftijd was het percentage dieren zonder staartbeschadigingen, het percentage dieren met een intacte staartlengte en het percentage dieren zonder oorbeschadigingen vergelijkbaar bij de dieren die wel of geen extra vezels in het voer kregen. Ook het aantal keer staartbijten, oorbijten en anders bijten op 7 weken leeftijd was vergelijkbaar bij de biggen die wel of geen extra vezels in het voer kregen. Het verstrekken van extra vezels via het voer heeft bij biggen in de kraamstal en bij gespeende biggen dus niet geresulteerd in minder bijtgedrag en minder staart- en oorschade. Tijdens het onderzoek is 5,5\% van de gespeende biggen uitgevallen vanwege een infectie met S. suis. Dit was vergelijkbaar bij de biggen die wel of geen extra vezels kregen. Ook zijn alle dieren via het drinkwater behandeld vanwege een S. suis infectie. Een verminderde gezondheid verhoogt de kans op bijtgedrag (Moinard et al., 2003; Taylor et al., 2010). Het te verwachte effect van vezels op de vermindering van bijtgedrag (Bolhuis et al., 2010) is mogelijk teniet gedaan door de verminderde gezondheid van de gespeende biggen. 
Op 14 en 18 weken leeftijd was het percentage dieren zonder staartbeschadiging en het percentage dieren met een intacte staartlengte hoger bij de dieren die extra vezels in het voer kregen. Daarnaast was het percentage dieren met een zichtbare wond (m.n. op 14 weken leeftijd) lager en zijn er duidelijk minder vleesvarkens naar de noodopvang verplaatst vanwege een aangebeten staart ( 7 versus 1 dier). Het verstrekken van extra vezels via het voer heeft bij de vleesvarkens dus geresulteerd in minder staartschade. Soortgelijke resultaten zijn gevonden in de literatuur. Extra vezels zorgen voor verlenging van de eettijd en meer verzadiging, resulterend in minder manipulatief gedrag gericht op hokgenoten (Bolhuis et al., 2010), minder oraal gedrag (Brouns et al., 1994) en een lagere kans op staartbijten (Taylor et al., 2010).

De dag voor afleveren was het percentage dieren zonder staartbeschadiging en het percentage dieren met een zichtbare wond vergelijkbaar bij wel of geen extra vezels in het voer. Het percentage dieren zonder staartbeschadigingen was de dag voor afleveren veel hoger dan gedurende het vleesvarkenstraject. Dit is mogelijk het gevolg van het inzetten van het vangnet en is mogelijk ook de reden dat er geen verschil in staartschade is tussen wel of geen extra vezels in het voer. Het percentage dieren met een intacte staartlengte is de dag voor afleveren wel duidelijk hoger bij extra vezels in het voer.

Geconcludeerd kan worden dat het verstrekken van extra vezels in het voer het percentage vleesvarkens met staartbeschadigingen verlaagde. Echter, ook bij extra vezels in het voer kwamen staartbeschadigingen voor. Staartbijten is een multifactorieel probleem (Taylor et al., 2010; D'Eath et al., 2014) en kan niet volledig voorkomen worden door alleen extra vezels of een combinatie van extra vezels en extra aminozuren toe te voegen aan het voer (Mclntyre and Edwards, 2002).

\section{Effect extra aminozuren}

Op 4 weken leeftijd was er geen effect van extra aminozuren in het voer op het percentage dieren zonder staartbeschadigingen en het percentage dieren met een intacte staart. Op 9 weken leeftijd was het percentage dieren zonder staartbeschadigingen en het percentage biggen met een intacte staartlengte echter iets lager bij extra aminozuren in het voer. Het aantal keer staartbijten, oorbijten en anders bijten op 7 weken leeftijd was vergelijkbaar bij de biggen die wel of geen extra aminozuren in het voer kregen. Het verstrekken van extra aminozuren via het voer heeft bij gespeende biggen dus niet geresulteerd in minder bijtgedrag en minder staart- en oorschade. Dit is in tegenstelling met de resultaten van Martinez-Trejo et al. (2009). Zij zagen duidelijk minder bijtgedrag en minder agressief gedrag bij biggen die 17, 34 of 52\% extra tryptofaan in het voer kregen. Tryptofaan is een precursor voor de neurotransmitter serotonine en heeft invloed op het gedrag van mens en dier (Riedel et al., 2002). Uit diverse onderzoeken is gebleken dat een hoog tryptofaangehalte in het voer resulteert in rustigere dieren (Mcl ntyre and Edwards, 2002), minder vechten (Li et al., 2006) en minder staart- en oorbijten (Martinez-Trejo et al. (2009). De reden waarom wij op 9 weken leeftijd geen of zelfs een negatief effect vinden van extra aminozuren in het voer is niet helemaal duidelijk. Mogelijk heeft de verminderde gezondheid van de biggen een rol gespeeld. Bij de gespeende biggen die extra aminozuren in het voer kregen, zijn meer dieren behandeld vanwege luchtwegaandoeningen. Kritas and Morrison (2007) en Monaird et al. (2003) geven aan dat er een positieve relatie is tussen luchtwegaandoeningen en staartbijten. Daarnaast hebben de gespeende biggen die extra aminozuren in het voer kregen minder voer opgenomen en zijn langzamer gegroeid. Een lagere groei als gevolg van een mindere gezondheid kan de incidentie van bijtgedrag verhogen (Taylor et al., 2010).

Op 18 weken leeftijd en de dag voor afleveren was het percentage dieren zonder staartbeschadiging hoger bij extra aminozuren in het voer. Daarnaast vertoonden de vleesvarkens op 21 weken leeftijd minder staartbijtgedrag bij extra aminozuren in het voer. Deze resultaten komen overeen met die van Mcl ntyre and Edwards (2000a) en Martinez-Trejo et al. (2009). Het percentage dieren met een intacte staartlengte was op 18 weken leeftijd en bij afleveren wel lager bij extra aminozuren in het voer. Dit verschil is echter al ontstaan tijdens de opfokperiode en tijdens het begin van de vleesvarkensperiode.

Geconcludeerd kan worden dat het verstrekken van extra aminozuren in het voer het percentage vleesvarkens zonder staartbeschadigingen bij afleveren verhoogde. Het percentage vleesvarkens met een intacte staartlengte was echter lager bij extra aminozuren in het voer. 


\subsection{Technische resultaten}

\section{Effect extra vezels}

Er waren geen verschillen in voeropname, groei en voederconversie tussen gespeende biggen die wel of geen extra vezels in het voer kregen. De toevoeging van 10\% vezelrijke grondstoffen aan het speenvoer en opfokvoer ( $5 \%$ haverschalen, $3 \%$ bietenpulp en $2 \%$ cichorei) heeft de voeropname en de groei dus niet verlaagd. Ook Paredes (2014) vond geen verschillen in voeropname en groei tussen gespeende biggen die een controlevoer of een vezelrijk voer kregen. Zij vond wel een negatief effect op de voederconversie van het verstrekken van een vezelrijk voer. In haar onderzoek was het aandeel vezelrijke grondstoffen in het voer veel hoger dan in ons onderzoek. Daarnaast gebruikte zij hoge kwaliteit eiwitbronnen in het controlevoer en lagere kwaliteit eiwitbronnen in het vezelrijke voer. Mogelijk verklaart de combinatie van veel vezels en lagere kwaliteit eiwitbronnen het negatieve effect op de voederconversie.

De vleesvarkens die extra vezels in het voer kregen namen minder voer (2,23 vs 2,29 kg/d) op en groeiden langzamer ( 907 vs $930 \mathrm{~g} / \mathrm{d}$ ) dan de vleesvarkens die geen extra vezels in het voer kregen. Daarnaast was het vleespercentage hoger $(59,4$ vs 58,9\%), de spekdikte lager (13,5 vs $14,2 \mathrm{~mm})$ en het aanhoudingspercentage lager (77,3 vs 77,8\%) bij de vleesvarkens die extra vezels in het voer kregen. Soortgelijke resultaten zijn gevonden door Van der Peet-Schwering et al. (2006). Het voer met extra vezels bevatte een hoger gehalte aan fermenteerbare koolhydraten dan het voer zonder extra vezels. Uit diverse onderzoeken met onbeperkt gevoerde drachtige zeugen is gebleken dat de voeropname beperkt kan worden door de zeugen een voer met een hoog gehalte aan fermenteerbare koolhydraten te geven (Brouns et al., 1995; Whittaker et al., 2000; Van der Peet-Schwering e.a., 2003). Fermenteerbare vezels vertragen de maaglediging en hebben een hoog waterbindend vermogen (Guérin et al., 2001) waardoor zeugen zich mogelijk sneller verzadigd voelen. Daarnaast stabiliseren ze het glucosegehalte in het bloed (De Leeuw, 2004) en blijft het glucosegehalte in het bloed langer op een hoog niveau (Vestergaard, 1997), waardoor de zeugen zich langere tijd verzadigd voelen. Uit het onderzoek van Van der Peet-Schwering et al. (2006) en ons onderzoek blijkt dat voer met een hoger gehalte aan fermenteerbare koolhydraten ook bij onbeperkt gevoerde vleesvarkens de voeropname kan beperken en het vleespercentage kan verbeteren.

\section{Effect extra aminozuren}

De gespeende biggen die extra aminozuren in het voer kregen namen de eerste twee weken na spenen minder voer op, groeiden langzamer en hadden een ongunstigere voederconversie dan de biggen die geen extra aminozuren in het voer kregen. Van dag 14 tot dag 35 na spenen en tijdens de vleesvarkensperiode waren er geen verschillen in voeropname, groei en voederconversie tussen de dieren die wel of geen extra aminozuren in het voer kregen. Deze resultaten komen niet overeen met die van Van der Meer et al. (2016a). Zij vonden bij vleesvarkens een positief effect op de voeropname, groei en voederconversie van $20 \%$ extra darmverteerbaar methionine+cystine, threonine en tryptofaan in vleesvarkensvoeders. Zij concludeerden dat methionine, threonine en tryptofaan mogelijk limiterend waren in de vleesvarkensvoeders zonder extra aminozuren en dat de extra toevoeging daarom resulteerde in een verbetering van de technische resultaten. De gehalten aan darmverteerbaar lysine, threonine en tryptofaan in de voeders zonder extra aminozuren waren redelijk vergelijkbaar in het onderzoek van Van der Meer et al. (2016) en in ons onderzoek. Het darmverteerbaar methionine+cystine gehalte in de voeders zonder extra aminozuren was in het onderzoek van Van der Meer et al. (2016) echter ca. 20\% lager dan in ons onderzoek en dan geadviseerd door het CVB (CVB, 2012) waardoor de dieren een tekort aan darmverteerbaar methionine+cystine kregen. Dit verklaart waarschijnlijk de lagere groei bij de vleesvarkens die geen extra aminozuren in het voer kregen. In ons onderzoek was er geen sprake van een tekort aan aminozuren voor groei, waardoor we geen verbetering hebben gevonden van de technische resultaten van extra aminozuren in het voer. 


\section{Conclusies}

Onderzocht is of bijtgedrag (staart-, oor- en flankbijten) en bijtschade (staart- en oorschade) bij dieren met een intacte (niet gecoupeerde) staart verminderd kunnen worden door de dieren vanaf enkele dagen na geboorte tot afleveren naar het slachthuis voer met extra vezels (verzadigend voer) en/of extra aminozuren (tryptofaan, threonine en methionine) te geven. Daarnaast is nagegaan wat het effect van deze voeders is op de technische en financiële resultaten van gespeende biggen en vleesvarkens. De belangrijkste conclusies uit het onderzoek zijn:

Bijtgedrag en staart- en oorschade:

- Staartbijten kwam al in de kraamstal voor. Bij spenen op 4 weken leeftijd had $64 \%$ van de dieren geen staartbeschadiging, $24 \%$ had bijtsporen en $12 \%$ had een zichtbare wond.

- Op 14 en 18 weken leeftijd was het percentage dieren zonder staartbeschadigingen lager dan de dag voor afleveren (respectievelijk 61, 58 en $81 \%$ op 14 en 18 weken leeftijd en de dag voor afleveren) en het percentage dieren met een zichtbare wond hoger (respectievelijk 21 , 29 en $18 \%$ op 14 en 18 weken leeftijd en de dag voor afleveren). Aan het eind van de vleesvarkens periode zijn de staartbeschadigingen mogelijk deels hersteld door inzet van het vangnet.

- $\quad$ Bij afleveren had $81 \%$ van de vleesvarkens geen staartbeschadiging, $1 \%$ had bijtsporen en $18 \%$ had een zichtbare wond.

- Het percentage dieren met een intacte staartlengte (er mist geen deel van de staart) daalde van $98 \%$ op 4 weken leeftijd naar $77 \%$ daags voor afleveren.

- Oorbeschadigingen kwamen het meeste voor bij de gespeende biggen (17\% van de biggen op 9 weken leeftijd) en in veel mindere mate bij de vleesvarkens (3\% van de vleesvarkens daags voor afleveren).

- Het verstrekken van extra vezels of van extra aminozuren in het voer heeft bij biggen in de kraamstal en bij gespeende biggen niet geresulteerd in minder bijtgedrag en minder staarten oorschade.

- $\quad$ Bij de vleesvarkens resulteerde het verstrekken van extra vezels via het voer in minder staartschade (hoger percentage dieren zonder staartbeschadiging; hoger percentage dieren met een intacte staartlengte; lager percentage dieren met een zichtbare staartwond; minder dieren naar noodopvang vanwege aangebeten staart (respectievelijk 3,3 en 0,4\% van de vleesvarkens bij geen en wel extra vezels in het voer).

- Het verstrekken van extra aminozuren in het voer verhoogde het percentage vleesvarkens zonder staartbeschadigingen bij afleveren (respectievelijk 75,2 en 85,5\% bij geen en wel extra aminozuren in het voer). Het percentage vleesvarkens met een intacte staartlengte was echter lager bij extra aminozuren in het voer (respectievelijk 80,6 en $73,1 \%$ bij geen en wel extra aminozuren in het voer).

Inzet vangnet:

- In de biggenopfokstal is in 11 van de 48 hokken een vangnet (touw en luzerne) ingezet gedurende 2 tot 19 dagen. Bij 85\% van de biggen was de staart- of oorwond na een week hersteld en kon gestopt worden met het inzetten van het vangnet.

- $\quad$ Eén hok (met vezelrijk voer) met ingezet vangnet vanwege staartbijten is ca. 3,5 weken na spenen uit het onderzoek genomen vanwege ernstig vechten van de dieren. Er waren enkele dieren in het hok, die continue het gevecht aangingen met de andere dieren in het hok, waardoor een deel van de dieren wonden aan de nek hadden. Het is niet duidelijk waarom deze dieren steeds het gevecht aangingen.

- $\quad$ Bij de vleesvarkens is in 27 van de 47 hokken een vangnet (touw en luzerne) ingezet gedurende 1 tot 5 weken. De meeste vleesvarkens hadden drie dagen na inzet van het vangnet een korst op de staartwond 
Technische en financiële resultaten:

- $\quad$ Er waren geen verschillen in voeropname, groei en voederconversie tussen gespeende biggen die wel of geen extra vezels in het voer kregen.

- De vleesvarkens die extra vezels in het voer kregen namen minder voer op, groeiden langzamer, hadden dunner spek en hadden een hoger vleespercentage dan de vleesvarkens die geen extra vezels in het voer kregen.

- De gespeende biggen die extra aminozuren in het voer kregen namen de eerste twee weken na spenen minder voer op, groeiden langzamer en hadden een ongunstigere voederconversie dan de biggen die geen extra aminozuren in het voer kregen. Van dag 14 tot dag 35 na spenen en tijdens de vleesvarkensperiode waren er geen verschillen in voeropname, groei en voederconversie tussen de dieren die wel of geen extra aminozuren in het voer kregen.

- Het financiële resultaat per afgeleverde big was hoger bij de biggen die het controlevoer kregen dan bij de biggen die het controlevoer met extra aminozuren kregen. Het financiële resultaat per afgeleverde big van de biggen die het vezelrijke voer of het vezelrijke voer met extra aminozuren kregen zat hier tussen in.

- Het saldo per afgeleverd vleesvarken was het hoogst was bij de vleesvarkens die het controlevoer kregen a.g.v. een hogere opbrengst en lagere voerkosten per afgeleverd vleesvarken. Het saldo per afgeleverd vleesvarkens verschilde niet tussen de vleesvarkens die het vezelrijke voer, het voer met extra aminozuren of het vezelrijke voer met extra aminozuren kregen.

Samenvattend kan geconcludeerd worden dat met name het verstrekken van extra vezels in het voer resulteerde in een hoger percentage vleesvarkens zonder staartschade (het percentage dieren met een intacte staartlengte bij afleveren naar het slachthuis was respectievelijk 71 en $82 \%$ bij geen en wel extra vezels in het voer). Echter, ook bij extra vezels in het voer kwam staartschade voor.

Staartbijten is een multifactorieel probleem en kon in dit onderzoek niet volledig voorkomen worden door alleen extra vezels of een combinatie van extra vezels en extra aminozuren toe te voegen aan het voer. Een vangnet was nodig om bijtgedrag zo snel mogelijk te stoppen. 


\section{Literatuur}

Amory, J.R., A.M. Mackenzie and G.P. Pearce. 2006. Factors in the housing environment of finisher pigs associated with the development of gastric ulcers. Veterinary Record, 158, 260-264.

Bolhuis, J.E., H. van den Brand, A.C. Bartels, M. Oostindjer, J.J.G.C. van den Borne, B. Kemp, W.J.J. Gerrits. 2010. Effects of fermentable starch on behaviour of growing pigs in barren or enriched housing. Applied Animal Behaviour Science, 123, 77-86.

Brouns, F.S., S.A. Edwards and P.R. English. 1995. Influence of fibrous ingredients on voluntary feed intake of dry sows. Animal Feed Science and Technology, 54, 301-313.

D'Eath, R.B. 2002. Individual aggressiveness measured in a resident-intruder test predicts the persistence of aggressive behaviour and weight gain of young pigs after mixing. Applied Animal Behaviour Science, 77, 267-283.

D'Eath, R.B., G. Arnoot, S.P. Turner, T. Jensen, H.P. Lahrmann, M.E. Busch, J.K. Niemi, A.B. Lawrence and $P$. Sandoe. 2014. Injurious tail biting in pigs: how can it be controlled in existing systems without tail docking? Animal, 8:9, 1479-1497.

Elbers, A.R.W., J.H. Vos, G. Hemke and W.A. Hunneman. 1995. Effect of hammer mill screen size and addition of fibre of S-methylmethionine-sulphonium chloride to the diet on the occurrence of oesophagogastric lesions in fattening pigs. The Veterinary Record, 16, 290-293.

Elbers, A.R.W. en A. Dirkzwager 1994. Maagslijmvliesveranderingen bij varkens: een literatuuroverzicht. Tijdschrift voor Diergeneeskunde, 119, 22, 669-674.

Guérin, S., Y. Ramonet, M.C. Meunier-Salaün, J. De Cloarec, P. Bourguet and C.H. Malbert, 2001. Dietary fibres reduced gastric emptying rate as a consequence of impaired distal stomach function in conscious pigs. British Journal of Nutrition, 85, 343-350.

Kritas, S.K. and R.B. Morrison. 2004. An observational study on tail biting in commercial growerfinisher barns. Journal of Swine Health Production, 12, 17-22.

Leeuw, J.A. de. 2004. Stimulation of behavioural and nutritional satiety in sows. PhD Thesis, Wageningen University, Wageningen, The Netherlands.

Li, Y.Z., B.J. Kerr, K.T. Kidd and H.W. Gonyou. 2006. Use of supplementary tryptophan to modify the behaviour of pigs. Journal of Animal Science, 84, 212-220.

Martinez-Trejo, G., M.E. Ortega-Cerrilla, L.F. Rodarte-Covarrubias, J.G. Herrera-Haro, J.L. FigueroaVelasco, F. Galindo-Maldonado, O. Sánchez-Martinez and A. Lara-Bueno. 2009. Aggressiveness and productive performance of piglets supplemented with tryptophan. Journal of Animal and Veterinary Advances, 8, 4, 608-611.

Mclntyre, J. and S.A. Edwards. 2002. An investigation into the effect of different protein and energy intakes on model tail chewing behaviour of growing pigs. Applied Animal Behaviour Science, 77, 2, 93104.

Mclntyre, J. and S.A. Edwards. 2000a. An investigation into the effect of tryptophan on tail chewing behaviour of growing pigs. In: Proceedings of the British Society of Animal Science, 34. 
Meer, Y. van der, W.J .J. Gerrits, B. Kemp and J.E. Bolhuis. 2016. Low dietary amino acid supply and housing under low sanitary conditions increases damaging behaviours in pigs. Abstract ISAE.

Meer, Y. van der, W.J.J. Gerrits en A.J.M. Jansman. 2016a. Het effect van aminozuuraanbod en samenstelling van het voer op zoötechnische prestaties van beren gehuisvest onder verschillende sanitaire condities. Vertrouwelijk rapport 445, Wageningen Livestock Research, Wageningen.

Moinard, C., M. Mendl, C.J. Nicol and L.E. Green. 2003. A case control study of on-farm risk factors for tail biting in pigs. Applied Animal Behaviour Science, 81, 333-355.

Paredes, S. 2014. Unveling causes for growth retardation in piglets. PhD thesis, Wageningen University, Wageningen.

Peet, G.F.V. van der, M. Kluivers-Poodt, N. Dirx, A. Hoofs, C.M.C. van der Peet-Schwering, G.P. Binnendijk, W.W. Ursinus, J.E. Bolhuis. 2016. Houden van varkens met een intacte staart. Invulling van stpa 1 van de Verklaring van Dalfsen: demonstratieproject, praktijknetwerk en internationale samenwerking. Rapport 939, Wageningen Livestock Research, Wageningen.

Peet-Schwering, C.M.C. van der, J.P. Plagge en G.P. Binnendijk. 2006. Effect van verzadigend voer en ruwvoer op de slachtkwaliteit van biologische vleesvarkens. Rapport 05, Wageningen Livestock Research, Wageningen.

Peet-Schwering, C.M.C. van der, J.G. Plagge en G.P. Binnendijk. 2003. Onbeperkt voeren van drachtige zeugen in groepshuisvesting. PraktijkRapport Varkens 22, Animal Sciences Group, Wageningen UR, Lelystad.

Riedel, W.J., T. Klaassen and J.A.J. Schmitt. 2002. Tryptophan, mood, and cognitive function. Brain Behavior and Immunity, 16, 581-589.

Taylor, N.R., D.C.J. Main, M. Mendl and S.A. Edwards. 2010. Tail-biting: A new perspective. The Veterinary Journal, 186, 137-147.

Ursinus, W.W., H.J. Wijnen, A.C. Bartels, N. Duijvesteijn, C.G. van Reenen and J.E. Bolhuis. 2014. Damaging biting behaviors in intensively kept rearing gilts: The effect of jute sacks and relations with production characteristics. Journal of Animal Science, 92, 5193-5202.

Vestergaard, E.-M., 1997. The effect of dietary fibre on welfare and productivity of sows. Ph.D. dissertation, Research Centre Foulum, Denmark.

Whittaker, X.S., S.A. Edwards, H.A.M. Spoolder, S. Corning and A.B. Lawrence, 2000. The performance of group-housed sows offered a high fibre diet ad libitum. Animal Science, 70, 85-93. 


\section{Bijlage 1 Samenstelling biggenvoer}

\begin{tabular}{|c|c|c|c|c|c|}
\hline & & Controlevoer & $\begin{array}{c}\text { Vezelrijk } \\
\text { voer }\end{array}$ & $\begin{array}{c}\text { Voer met extra } \\
\text { az }\end{array}$ & $\begin{array}{c}\text { Vezelrijk voer met } \\
\text { extra az }\end{array}$ \\
\hline AARDAPPELEI WIT & $\%$ & 2.000 & 2.000 & 2.000 & 2.000 \\
\hline GERST & $\%$ & 32.000 & 31.500 & 32.000 & 31.500 \\
\hline TARWEGRIES & $\%$ & 2.500 & 2.500 & 2.500 & 2.500 \\
\hline MAÏS & $\%$ & 5.000 & 5.000 & 5.000 & 5.000 \\
\hline TARWE & $\%$ & 20.000 & 6.000 & 20.000 & 6.000 \\
\hline SOJ ABONEN GEËXTRUDEERD & $\%$ & 6.500 & 6.600 & 6.500 & 6.500 \\
\hline TARWEVOERBLOEM & $\%$ & 7.073 & 9.776 & 6.576 & 9.802 \\
\hline SOJA OLIE & $\%$ & 0.045 & 1.498 & 0.079 & 1.500 \\
\hline SOJASCHROOT & $\%$ & 4.500 & 4.797 & 4.500 & 4.500 \\
\hline HAVERSCHILLENMEEL & $\%$ & 0.000 & 5.000 & 0.000 & 5.000 \\
\hline BIETENPULP & $\%$ & 0.000 & 3.000 & 0.000 & 3.000 \\
\hline WEI POEDER & $\%$ & 2.500 & 2.500 & 2.500 & 2.500 \\
\hline MAÏSGLUTENMEEL & $\%$ & 2.000 & 2.000 & 2.000 & 2.000 \\
\hline HAVERMOUT ONTSLOTEN & $\%$ & 6.500 & 6.500 & 6.500 & 6.500 \\
\hline $\mathrm{CICHOREI}$ & $\%$ & 0.000 & 2.000 & 0.000 & 2.000 \\
\hline SOYCOMILL & $\%$ & 1.000 & 1.500 & 1.000 & 1.500 \\
\hline PREMIX & $\%$ & 8.382 & 7.829 & 8.845 & 8.198 \\
\hline Ruw Eiwit & $\mathrm{g} / \mathrm{kg}$ & 167.400 & 166.000 & 169.000 & 166.630 \\
\hline Ruwe Celstof & $\mathrm{g} / \mathrm{kg}$ & 29.430 & 49.550 & 29.390 & 49.380 \\
\hline Ruw Vet Extr & $\mathrm{g} / \mathrm{kg}$ & 49.000 & 61.380 & 49.460 & 61.130 \\
\hline Ruw As & $\mathrm{g} / \mathrm{kg}$ & 48.910 & 51.340 & 49.870 & 51.460 \\
\hline Vocht & $\mathrm{g} / \mathrm{kg}$ & 109.690 & 106.220 & 109.100 & 105.800 \\
\hline Zetmeel Ew & $\mathrm{g} / \mathrm{kg}$ & 418.570 & 352.680 & 415.510 & 352.650 \\
\hline Calcium & $\mathrm{g} / \mathrm{kg}$ & 5.450 & 5.300 & 5.600 & 5.400 \\
\hline P.Vertb & $\mathrm{g} / \mathrm{kg}$ & 3.900 & 3.900 & 3.900 & 3.900 \\
\hline Natrium & $\mathrm{g} / \mathrm{kg}$ & 2.800 & 2.800 & 3.000 & 2.800 \\
\hline Chloor & $\mathrm{g} / \mathrm{kg}$ & 5.830 & 5.720 & 6.130 & 5.740 \\
\hline Kalium & $\mathrm{g} / \mathrm{kg}$ & 6.680 & 7.290 & 6.650 & 7.210 \\
\hline $\mathrm{dEB}$ & meq & 128.000 & 147.000 & 128.000 & 144.000 \\
\hline $\mathrm{EW}(x 100)$ & - & 114.000 & 114.000 & 114.000 & 114.000 \\
\hline NSP & $\mathrm{g} / \mathrm{kg}$ & 139.200 & 185.620 & 138.460 & 184.780 \\
\hline Vit E -Added & $\mathrm{mg} / \mathrm{kg}$ & 150.000 & 150.000 & 150.000 & 150.000 \\
\hline il-lys Va & $\mathrm{g} / \mathrm{kg}$ & 10.370 & 10.370 & 10.370 & 10.370 \\
\hline $\mathrm{il}-\mathrm{m}+\mathrm{c}$ Va & $\mathrm{g} / \mathrm{kg}$ & 6.270 & 6.270 & 7.520 & 7.520 \\
\hline il-treo Va & $\mathrm{g} / \mathrm{kg}$ & 6.160 & 6.160 & 7.390 & 7.390 \\
\hline il-tryp Va & $\mathrm{g} / \mathrm{kg}$ & 1.940 & 1.940 & 2.520 & 2.520 \\
\hline il LNAA & & 34.090 & 33.260 & 33.950 & 32.880 \\
\hline ilm+cVa/il-lysVa & - & 60.500 & 60.500 & 72.500 & 72.500 \\
\hline iltreoVa/il-lysVa & - & 59.400 & 59.400 & 71.300 & 71.300 \\
\hline iltrypVa/il-lysVa & - & 18.700 & 18.700 & 24.300 & 24.300 \\
\hline
\end{tabular}


Opfokvoer

\begin{tabular}{|c|c|c|c|c|c|}
\hline & & Controlevoer & $\begin{array}{l}\text { Vezelrijk } \\
\text { voer }\end{array}$ & $\begin{array}{c}\text { Voer met extra } \\
\text { az }\end{array}$ & $\begin{array}{c}\text { Vezelrijk voer met extra } \\
\text { az }\end{array}$ \\
\hline GERST & $\%$ & 30.000 & 30.000 & 30.000 & 30.000 \\
\hline TARWEGRIES & $\%$ & 3.500 & 3.500 & 3.500 & 3.500 \\
\hline MAÏS & $\%$ & 7.500 & 7.500 & 7.500 & 7.500 \\
\hline TARWE & $\%$ & 30.930 & 14.621 & 30.994 & 14.635 \\
\hline DANEX & $\%$ & 5.000 & 5.000 & 5.000 & 5.000 \\
\hline VOERHAVERMEEL & $\%$ & 5.000 & 5.000 & 5.000 & 5.000 \\
\hline SOJA OLIE & $\%$ & 0.734 & 3.993 & 0.738 & 4.036 \\
\hline SOJ ASCHROOT & $\%$ & 12.839 & 16.172 & 12.301 & 15.642 \\
\hline HAVERSCHALEN & $\%$ & 0.000 & 5.000 & 0.000 & 5.000 \\
\hline BIETENPULP & $\%$ & 0.000 & 3.000 & 0.000 & 3.000 \\
\hline $\mathrm{CICHOREI}$ & $\%$ & 0.000 & 2.000 & 0.000 & 2.000 \\
\hline BIOLYS70 & $\%$ & 0.737 & 0.632 & 0.761 & 0.658 \\
\hline DL-METHIONINE & $\%$ & 0.165 & 0.179 & 0.294 & 0.309 \\
\hline L-THREONINE & $\%$ & 0.172 & 0.157 & 0.302 & 0.288 \\
\hline VM825 TRYPTOFAAN 25 & $\%$ & 0.135 & 0.130 & 0.379 & 0.374 \\
\hline PREMIX & $\%$ & 3.288 & 3.116 & 3.231 & 3.058 \\
\hline Ruw Eiwit & $\mathrm{g} / \mathrm{kg}$ & 170.000 & 170.000 & 170.000 & 170.000 \\
\hline Ruwe Celstof & $\mathrm{g} / \mathrm{kg}$ & 39.060 & 54.790 & 38.920 & 54.630 \\
\hline Ruw Vet Extr & $\mathrm{g} / \mathrm{kg}$ & 40.000 & 71.410 & 40.000 & 71.790 \\
\hline Ruw As & $\mathrm{g} / \mathrm{kg}$ & 46.070 & 48.380 & 46.320 & 48.620 \\
\hline Vocht & $\mathrm{g} / \mathrm{kg}$ & 124.470 & 116.080 & 124.020 & 115.580 \\
\hline Zetmeel Ew & $\mathrm{g} / \mathrm{kg}$ & 427.060 & 333.810 & 427.410 & 333.850 \\
\hline Suikers & $\mathrm{g} / \mathrm{kg}$ & 35.400 & 38.190 & 34.920 & 37.700 \\
\hline Calcium & $\mathrm{g} / \mathrm{kg}$ & 6.350 & 6.250 & 6.350 & 6.250 \\
\hline P.Vertb & $\mathrm{g} / \mathrm{kg}$ & 3.400 & 3.400 & 3.400 & 3.400 \\
\hline Natrium & $\mathrm{g} / \mathrm{kg}$ & 3.000 & 2.800 & 3.000 & 2.800 \\
\hline Chloor & $\mathrm{g} / \mathrm{kg}$ & 4.540 & 4.160 & 4.530 & 4.160 \\
\hline Kalium & $\mathrm{g} / \mathrm{kg}$ & 7.430 & 7.900 & 7.330 & 7.790 \\
\hline $\mathrm{dEB}$ & meq & 193.000 & 207.000 & 190.000 & 204.000 \\
\hline $\mathrm{EW}(\mathrm{x} 100)$ & - & 112.149 & 112.000 & 112.048 & 112.000 \\
\hline NSP & $\mathrm{g} / \mathrm{kg}$ & 160.373 & 203.394 & 159.673 & 202.665 \\
\hline Vit E -Added & $\mathrm{mg} / \mathrm{kg}$ & 150.000 & 150.000 & 150.000 & 150.000 \\
\hline il-lys Va & $\mathrm{g} / \mathrm{kg}$ & 10.206 & 10.192 & 10.196 & 10.192 \\
\hline il-meth Va & $\mathrm{g} / \mathrm{kg}$ & 3.761 & 3.875 & 5.010 & 5.130 \\
\hline il- $m+c$ Va & $\mathrm{g} / \mathrm{kg}$ & 6.123 & 6.115 & 7.341 & 7.338 \\
\hline il-treo Va & $\mathrm{g} / \mathrm{kg}$ & 6.021 & 6.013 & 7.219 & 7.216 \\
\hline il-tryp Va & $\mathrm{g} / \mathrm{kg}$ & 1.939 & 1.936 & 2.518 & 2.517 \\
\hline il LNAA & $\mathrm{g} / \mathrm{kg}$ & 32.470 & 33.023 & 31.898 & 32.449 \\
\hline ilmethVa/il-lysVa & - & 0.369 & 0.380 & 0.491 & 0.503 \\
\hline ilm+cVa/il-lysVa & - & 0.600 & 0.600 & 0.720 & 0.720 \\
\hline iltreoVa/il-lysVa & - & 0.590 & 0.590 & 0.708 & 0.708 \\
\hline iltrypVa/il-lysVa & - & 0.190 & 0.190 & 0.247 & 0.247 \\
\hline
\end{tabular}




\section{Bijlage 2 Samenstelling vleesvarkensvoer}

\begin{tabular}{|c|c|c|c|c|c|}
\hline & & Controlevoer & $\begin{array}{c}\text { Vezelrijk } \\
\text { voer }\end{array}$ & $\begin{array}{c}\text { Voer met extra } \\
\text { az }\end{array}$ & $\begin{array}{c}\text { Vezelrijk voer met extra } \\
\text { az }\end{array}$ \\
\hline MAIS & $\%$ & 12.000 & 11.747 & 12.000 & 11.026 \\
\hline GERST & $\%$ & 29.700 & 29.700 & 30.084 & 29.700 \\
\hline TARWE & $\%$ & 26.830 & 14.850 & 26.553 & 14.850 \\
\hline CORNSTEEP & $\%$ & 2.500 & 1.330 & 2.500 & 2.500 \\
\hline TARWEGRIES & $\%$ & 7.350 & 4.950 & 7.420 & 4.950 \\
\hline PALMOLIE-RUW & $\%$ & 0.493 & 2.500 & 0.492 & 2.500 \\
\hline SOYAOLIE RUW & $\%$ & 1.000 & 1.000 & 1.000 & 1.320 \\
\hline HAVERSCHALEN & $\%$ & 0.000 & 5.000 & 0.000 & 5.000 \\
\hline BIETENPULP & $\%$ & 0.000 & 3.960 & 0.000 & 3.960 \\
\hline SOYA HIPRO & $\%$ & 13.748 & 14.513 & 13.250 & 13.799 \\
\hline SOYAHULLEN & $\%$ & 0.000 & 1.000 & 0.000 & 1.000 \\
\hline RAAPSCHROOT & $\%$ & 2.475 & 2.475 & 2.475 & 2.376 \\
\hline 29-ZONNEPITSCHROOT & $\%$ & 0.000 & 2.970 & 0.000 & 2.970 \\
\hline L-METHIONINE & $\%$ & 0.097 & 0.112 & 0.214 & 0.227 \\
\hline LYSINE SULFAAT $70 \%$ & $\%$ & 0.566 & 0.543 & 0.590 & 0.569 \\
\hline THREONINE & $\%$ & 0.100 & 0.099 & 0.220 & 0.219 \\
\hline TRYPTOFAAN & $\%$ & 0.101 & 0.111 & 0.382 & 0.398 \\
\hline PREMIX & $\%$ & 3.040 & 3.140 & 2.820 & 2.636 \\
\hline Ruw Eiwit & $\%$ & 16.500 & 16.500 & 16.500 & 16.500 \\
\hline Ruwe Celstof & $\%$ & 3.750 & 6.204 & 3.750 & 6.155 \\
\hline Ruw Vet Extr & $\%$ & 3.975 & 5.970 & 3.976 & 6.183 \\
\hline Ruw As & $\%$ & 5.026 & 5.277 & 4.995 & 5.270 \\
\hline Vocht & $\%$ & 12.383 & 11.322 & 12.343 & 11.710 \\
\hline Zetmeel Ew & $\%$ & 42.275 & 35.100 & 42.301 & 34.603 \\
\hline Suikers & $\%$ & 3.623 & 3.860 & 3.617 & 3.828 \\
\hline Calcium & $\%$ & 0.700 & 0.700 & 0.700 & 0.700 \\
\hline P.Vertb & $\%$ & 0.269 & 0.260 & 0.268 & 0.260 \\
\hline Natrium & $\%$ & 0.230 & 0.230 & 0.230 & 0.230 \\
\hline Chloor & $\%$ & 0.388 & 0.386 & 0.388 & 0.381 \\
\hline Kalium & $\%$ & 0.795 & 0.788 & 0.785 & 0.806 \\
\hline dEB & meq & 194.265 & 193.106 & 191.681 & 198.925 \\
\hline $\mathrm{EW}(x 100)$ & - & 112.000 & 112.000 & 112.000 & 112.000 \\
\hline NSP & $\%$ & 15.099 & 20.906 & 15.180 & 20.850 \\
\hline Vit E -Added & $\mathrm{mg} / \mathrm{kg}$ & 120.000 & 120.000 & 120.000 & 120.000 \\
\hline il-lys Va & $\%$ & 0.930 & 0.930 & 0.930 & 0.930 \\
\hline il-meth Va & $\%$ & 0.315 & 0.330 & 0.429 & 0.443 \\
\hline $\mathrm{il}-\mathrm{m}+\mathrm{c}$ Va & $\%$ & 0.558 & 0.558 & 0.670 & 0.670 \\
\hline il-treo Va & $\%$ & 0.549 & 0.549 & 0.660 & 0.660 \\
\hline il-tryp Va & $\%$ & 0.177 & 0.177 & 0.230 & 0.230 \\
\hline il LNAA & $\%$ & 2.756 & 2.720 & 2.712 & 2.674 \\
\hline ilmethVa/il-lysVa & - & 0.339 & 0.355 & 0.462 & 0.476 \\
\hline ilm+cVa/il-lysVa & - & 0.600 & 0.600 & 0.720 & 0.720 \\
\hline iltreoVa/il-lysVa & - & 0.590 & 0.590 & 0.710 & 0.710 \\
\hline iltrypVa/il-lysVa & - & 0.190 & 0.190 & 0.247 & 0.247 \\
\hline
\end{tabular}


Tussenvoer

\begin{tabular}{|l|l|c|c|c|c|}
\hline & & Controlevoer & $\begin{array}{c}\text { Vezelrijk } \\
\text { voer }\end{array}$ & $\begin{array}{c}\text { Voer met extra } \\
\text { az }\end{array}$ & $\begin{array}{c}\text { Vezelrijk voer met extra } \\
\text { az }\end{array}$ \\
\hline MAIS & $\%$ & 14.200 & 14.750 & 14.200 & 14.750 \\
\hline GERST & $\%$ & 19.800 & 19.800 & 19.800 & 19.800 \\
\hline TARWE & $\%$ & 37.512 & 21.916 & 37.319 & 21.849 \\
\hline CORNSTEEP & $\%$ & 2.236 & 2.241 & 2.236 & 2.500 \\
\hline TARWEGRIES & $\%$ & 4.000 & 4.000 & 4.000 & 4.000 \\
\hline TARWEGLUTENVOERMEEL & $\%$ & 4.875 & 4.000 & 4.894 & 4.000 \\
\hline PALMOLIE-RUW & $\%$ & 0.490 & 2.500 & 0.490 & 2.500 \\
\hline SOJ AOLIE-RUW & $\%$ & 0.500 & 0.944 & 0.500 & 0.979 \\
\hline HAVERSCHALEN & $\%$ & 0.000 & 5.000 & 0.000 & 5.000 \\
\hline BIETENPULP & $\%$ & 0.000 & 4.000 & 0.000 & 4.000 \\
\hline SOJA HIPRO & $\%$ & 7.500 & 8.643 & 7.500 & 8.166 \\
\hline SOJ AHULLEN & $\%$ & 0.000 & 2.000 & 0.000 & 2.000 \\
\hline RAAPZAADSCHROOT & $\%$ & 4.950 & 4.950 & 4.950 & 4.950 \\
\hline 29-ZONNEPITSCHROOT & $\%$ & 1.486 & 3.000 & 1.417 & 3.000 \\
\hline L-METHIONINE 99\% & $\%$ & 0.040 & 0.055 & 0.139 & 0.157 \\
\hline LYSINE SULFAAT 70\% & $\%$ & 0.519 & 0.417 & 0.520 & 0.491 \\
\hline THREONINE & $\%$ & 0.072 & 0.068 & 0.168 & 0.169 \\
\hline TRYPTOFAAN & $\%$ & 0.057 & 0.072 & 0.296 & 0.321 \\
\hline PREMIX & $\%$ & 1.763 & 1.644 & 1.571 & 1.368 \\
\hline
\end{tabular}

\begin{tabular}{|c|c|c|c|c|c|}
\hline Ruw Eiwit & $\%$ & 15.021 & 15.000 & 15.155 & 15.000 \\
\hline Ruwe celstof & $\%$ & 4.272 & 6.887 & 4.250 & 6.870 \\
\hline Ruw vet Extr & $\%$ & 3.059 & 5.436 & 3.059 & 5.468 \\
\hline Ruw As & $\%$ & 4.492 & 4.789 & 4.481 & 4.757 \\
\hline Vocht & $\%$ & 12.378 & 11.727 & 12.348 & 11.795 \\
\hline Zetmeel Ew & $\%$ & 45.019 & 36.627 & 44.904 & 36.565 \\
\hline Suikers & $\%$ & 3.575 & 3.788 & 3.568 & 3.754 \\
\hline Calcium & $\%$ & 0.650 & 0.650 & 0.650 & 0.650 \\
\hline P.Totaal & $\%$ & 0.430 & 0.420 & 0.429 & 0.413 \\
\hline P.vertb & $\%$ & 0.256 & 0.250 & 0.255 & 0.245 \\
\hline Natrium & $\%$ & 0.140 & 0.140 & 0.140 & 0.140 \\
\hline Chloor & $\%$ & 0.232 & 0.227 & 0.231 & 0.226 \\
\hline Kalium & $\%$ & 0.721 & 0.761 & 0.719 & 0.759 \\
\hline$d E B$ & meq & 180.000 & 191.921 & 180.000 & 191.496 \\
\hline$E W(x 100)$ & - & 110.000 & 110.000 & 110.000 & 110.000 \\
\hline NSP & $\%$ & 15.491 & 21.723 & 15.520 & 21.726 \\
\hline Vit E - Added & $\mathrm{mg} / \mathrm{kg}$ & 100.000 & 100.000 & 100.000 & 100.000 \\
\hline il-lys Va & $\%$ & 0.781 & 0.781 & 0.781 & 0.781 \\
\hline il-meth Va & $\%$ & 0.246 & 0.260 & 0.344 & 0.359 \\
\hline il-m+c Va & $\%$ & 0.480 & 0.480 & 0.578 & 0.578 \\
\hline il-treo Va & $\%$ & 0.461 & 0.461 & 0.555 & 0.555 \\
\hline il-tryp Va & $\%$ & 0.148 & 0.148 & 0.195 & 0.195 \\
\hline il LNAA & $\%$ & 2.406 & 2.394 & 2.402 & 2.357 \\
\hline ilmethVa/il-lysVa & - & 0.315 & 0.333 & 0.441 & 0.460 \\
\hline ilm+cVa/il-lysVa & - & 0.615 & 0.615 & 0.740 & 0.740 \\
\hline iltreoVa/il-lysVa & - & 0.590 & 0.590 & 0.710 & 0.710 \\
\hline iltrypVa/il-lysVa & - & 0.190 & 0.190 & 0.250 & 0.250 \\
\hline
\end{tabular}


Eindvoer

\begin{tabular}{|c|c|c|c|c|c|}
\hline & & Controlevoer & $\begin{array}{c}\text { Vezelrijk } \\
\text { voer }\end{array}$ & $\begin{array}{l}\text { Voer met } \\
\text { extra az }\end{array}$ & $\begin{array}{c}\text { Vezelrijk } \\
\text { voer met } \\
\text { extra az }\end{array}$ \\
\hline MAIS & $\%$ & 9.900 & 9.900 & 9.900 & 9.800 \\
\hline GERST & $\%$ & 19.800 & 19.800 & 19.800 & 19.800 \\
\hline TARWE & $\%$ & 39.436 & 24.750 & 40.066 & 24.750 \\
\hline CORNSTEEP & $\%$ & 1.750 & 2.000 & 2.000 & 2.000 \\
\hline TARWEGRIES & $\%$ & 7.214 & 3.960 & 6.071 & 3.960 \\
\hline TARWEGLUTENVOERMEEL & $\%$ & 3.960 & 3.960 & 3.960 & 3.960 \\
\hline PALMOLIE-RUW & $\%$ & 0.490 & 2.500 & 0.490 & 2.500 \\
\hline SOJAOLIE RUW & $\%$ & 0.500 & 1.053 & 0.500 & 1.061 \\
\hline HAVERSCHALEN & $\%$ & 0.000 & 5.000 & 0.000 & 5.000 \\
\hline BIETENPULP & $\%$ & 0.000 & 4.000 & 0.000 & 4.000 \\
\hline SOJ A HIPRO & $\%$ & 4.950 & 6.953 & 4.950 & 6.280 \\
\hline SOJ AHULLEN & $\%$ & 0.000 & 5.000 & 0.000 & 5.000 \\
\hline RAAPZAADSCHROOT & $\%$ & 4.950 & 4.493 & 4.950 & 4.908 \\
\hline 29-ZONNEPITSCHROOT & $\%$ & 4.950 & 4.703 & 4.950 & 4.703 \\
\hline L-METHIONINE 99\% & $\%$ & 0.017 & 0.038 & 0.106 & 0.136 \\
\hline LYSINE SULFAAT $70 \%$ & $\%$ & 0.487 & 0.421 & 0.488 & 0.444 \\
\hline THREONINE & $\%$ & 0.054 & 0.052 & 0.141 & 0.154 \\
\hline TRYPTOFAAN & $\%$ & 0.009 & 0.036 & 0.233 & 0.268 \\
\hline PREMIX & $\%$ & 1.533 & 1.381 & 1.395 & 1.276 \\
\hline Ruw Eiwit & $\%$ & 14.770 & 14.600 & 14.900 & 14.600 \\
\hline Ruwe Celstof & $\%$ & 5.280 & 8.290 & 5.190 & 8.320 \\
\hline Ruw Vet Extr & $\%$ & 2.990 & 5.420 & 2.970 & 5.440 \\
\hline Ruw As & $\%$ & 4.350 & 4.620 & 4.330 & 4.590 \\
\hline Vocht & $\%$ & 12.030 & 11.620 & 12.210 & 11.590 \\
\hline Zetmeel Ew & $\%$ & 44.090 & 35.210 & 44.080 & 35.200 \\
\hline Suikers & $\%$ & 3.600 & 3.720 & 3.570 & 3.700 \\
\hline Calcium & $\%$ & 0.580 & 0.580 & 0.580 & 0.580 \\
\hline P.Totaal & $\%$ & 0.450 & 0.420 & 0.450 & 0.410 \\
\hline P.Vertb & $\%$ & 0.250 & 0.248 & 0.255 & 0.250 \\
\hline Natrium & $\%$ & 0.140 & 0.140 & 0.140 & 0.140 \\
\hline Chloor & $\%$ & 0.220 & 0.230 & 0.220 & 0.230 \\
\hline Kalium & $\%$ & 0.700 & 0.770 & 0.710 & 0.760 \\
\hline dEB & meq & 180.000 & 193.250 & 180.000 & 190.680 \\
\hline $\mathrm{EW}(\mathrm{x} 100)$ & - & 108.000 & 108.000 & 108.000 & 108.000 \\
\hline NSP & $\%$ & 17.300 & 23.920 & 17.020 & 24.010 \\
\hline Vit E -Added & $\mathrm{mg} / \mathrm{kg}$ & 100.000 & 100.000 & 100.000 & 100.000 \\
\hline il-lys Va & $\%$ & 0.720 & 0.720 & 0.720 & 0.720 \\
\hline il-meth Va & $\%$ & 0.220 & 0.240 & 0.310 & 0.330 \\
\hline il-m+c Va & $\%$ & 0.460 & 0.450 & 0.550 & 0.550 \\
\hline il-treo Va & $\%$ & 0.430 & 0.430 & 0.510 & 0.520 \\
\hline il-tryp Va & $\%$ & 0.140 & 0.140 & 0.180 & 0.180 \\
\hline il LNAA & $\%$ & 2.300 & 2.280 & 2.290 & 2.240 \\
\hline ilmethVa/il-lysVa & - & 0.310 & 0.330 & 0.430 & 0.460 \\
\hline ilm+cVa/il-lysVa & - & 0.630 & 0.630 & 0.760 & 0.760 \\
\hline iltreoVa/il-lysVa & - & 0.590 & 0.590 & 0.710 & 0.720 \\
\hline iltrypVa/il-lysVa & - & 0.190 & 0.190 & 0.250 & 0.250 \\
\hline
\end{tabular}




\section{Bijlage 3 Oranje hokkaart}

\begin{tabular}{|c|c|}
\hline \multicolumn{2}{|l|}{ Afdeling + hoknummer } \\
\hline Startdatum oranje kaart & \\
\hline 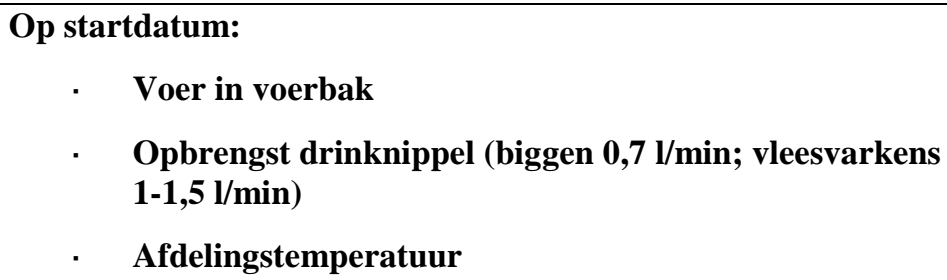 & 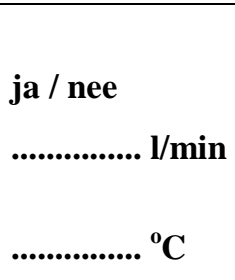 \\
\hline Einddatum oranje kaart & \\
\hline Dader(s) (bijters) aan te wijzen? & Ja / nee \\
\hline Diernummer(s) dader & \\
\hline Datum dader(s) uit hok (naar noodopvang) & \\
\hline
\end{tabular}

Beschrijving situatie en bijzonderheden op hokniveau

\begin{tabular}{|l|l|l|l|}
\hline Datum + tijd & Beschrijving van de verdachte situatie & Opmerkingen & Paraaf \\
\hline & & & \\
\hline & & & \\
\hline & & & \\
\hline & & & \\
\hline
\end{tabular}




\section{Bijlage 4 Rode hokkaart}

\begin{tabular}{|c|c|}
\hline \multicolumn{2}{|l|}{ Afdeling + hoknummer } \\
\hline Startdatum rode kaart & \\
\hline $\begin{array}{l}\text { Op startdatum: } \\
\text { - Voer in voerbak } \\
\text { - Opbrengst drinknippel (biggen 0,7 1/min; vleesvarkens } \\
\text { 1-1,5 l/min) } \\
\text { - Afdelingstemperatuur }\end{array}$ & ja / nee \\
\hline Einddatum rode kaart & \\
\hline Dader(s) (bijters) aan te wijzen? & ja / nee \\
\hline Diernummer(s) dader & \\
\hline $\begin{array}{l}\text { Datum dader(s) uit hok / naar noodopvang } \\
\text { (LET OP: vastleggen verplaatsing, gewicht en voertotaal in } \\
\text { FARM) }\end{array}$ & \\
\hline
\end{tabular}

Uitgevoerde acties op hokniveau bij inzet vangnet:

\begin{tabular}{|c|c|c|c|c|c|}
\hline$\underset{\text { tijd }}{\text { Datum }}+$ & $\begin{array}{c}\text { Touw } \\
\text { bevestigd } \mathrm{j} / \mathrm{n}\end{array}$ & $\begin{array}{c}\text { Touw } \\
\text { verwijderd } \mathbf{j} / \mathrm{n}\end{array}$ & $\begin{array}{l}\text { Aantal scheppen } \\
\text { luzerne verstrekt }\end{array}$ & Opmerkingen & Paraaf \\
\hline & & & & & \\
\hline & & & & & \\
\hline & & & & & \\
\hline & & & & & \\
\hline & & & & & \\
\hline & & & & & \\
\hline & & & & & \\
\hline & & & & & \\
\hline & & & & & \\
\hline & & & & & \\
\hline & & & & & \\
\hline
\end{tabular}




\section{Bijlage 5 Dierkaart}

\begin{tabular}{|l|l|}
\hline Diernummer & \\
\hline Afdeling + hoknummer & \\
\hline Datum $\mathbf{1}^{\mathbf{e}}$ constatering wond & \\
\hline Locatie wond bij $\mathbf{1}^{\mathbf{e}}$ constatering* & Staart / Oor / Flank \\
\hline Datum dier verplaatst naar noodopvang & \\
\hline Einddatum beoordeling wond & \\
\hline
\end{tabular}

Beoordeling en behandeling van de wond van het dier

\begin{tabular}{|c|c|c|c|c|c|c|c|}
\hline$\underset{\text { tijd }}{\text { Datum + }}$ & $\begin{array}{l}\text { Locatie } \\
\text { wond* }\end{array}$ & $\begin{array}{c}\text { Wond } \\
\text { grootte } \\
\text { (zie } \\
\text { onder) }\end{array}$ & $\begin{array}{c}\text { Vers } \\
\text { bloed } \\
\text { zichtbaar }\end{array}$ & $\begin{array}{c}\text { Korst op } \\
\text { wond }\end{array}$ & $\begin{array}{c}\text { Necrose } \\
\text { (afgestor-ven } \\
\text { weefsel) }\end{array}$ & $\begin{array}{c}\text { Behandeling } \\
\text { van de wond } \\
\text { (welke } \\
\text { spray) }\end{array}$ & Paraaf \\
\hline & St/ Oor/ FI & $1 / 2 / 3$ & Ja / nee & Ja / nee & Ja / nee & & \\
\hline & St/ Oor/ FI & $1 / 2 / 3$ & Ja / nee & Ja/ nee & Ja / nee & & \\
\hline & St/ Oor/ Fl & $1 / 2 / 3$ & Ja / nee & Ja / nee & Ja / nee & & \\
\hline & St/ Oor/ FI & $1 / 2 / 3$ & Ja / nee & Ja / nee & Ja / nee & & \\
\hline & St/ Oor/ FI & $1 / 2 / 3$ & Ja / nee & Ja/ nee & Ja / nee & & \\
\hline & St/ Oor/ FI & $1 / 2 / 3$ & Ja / nee & Ja / nee & Ja / nee & & \\
\hline & St/ Oor/ FI & $1 / 2 / 3$ & Ja / nee & Ja / nee & Ja / nee & & \\
\hline & St/ Oor/ FI & $1 / 2 / 3$ & Ja / nee & Ja/ nee & Ja / nee & & \\
\hline & St/ Oor/ FI & $1 / 2 / 3$ & Ja / nee & Ja / nee & Ja / nee & & \\
\hline & St/ Oor/ FI & $1 / 2 / 3$ & Ja / nee & Ja / nee & Ja / nee & & \\
\hline & St/ Oor/ FI & $1 / 2 / 3$ & Ja / nee & Ja / nee & Ja / nee & & \\
\hline & St/ Oor/ FI & $1 / 2 / 3$ & Ja / nee & Ja / nee & Ja / nee & & \\
\hline & St/ Oor/ FI & $1 / 2 / 3$ & Ja / nee & Ja / nee & Ja / nee & & \\
\hline & St/ Oor/ FI & $1 / 2 / 3$ & Ja / nee & Ja / nee & Ja / nee & & \\
\hline
\end{tabular}

Wondgrootte

\begin{tabular}{|l|l|l|l|}
\hline Staart & $\mathbf{1}$ & $\mathbf{2}$ & $\mathbf{3}$ \\
\hline Oor & $\begin{array}{l}\text { Klein, deel van punt } \\
\text { bloederig/beschadigd }\end{array}$ & $\begin{array}{l}\text { Groot, hele punt } \\
\text { bloederig/beschadigd }\end{array}$ & Deel van staart eraf \\
\hline Flank & $\begin{array}{l}\text { Klein, tot } 2 \mathrm{~cm} \text { van rand } \\
\text { beschadigd }\end{array}$ & $\begin{array}{l}\text { Groot, meer dan } 2 \mathrm{~cm} \\
\text { van rand beschadigd }\end{array}$ & Deel van oor weg \\
\hline
\end{tabular}




\section{Bijlage 6 Technische resultaten kraamstal}

Technische resultaten van zuigende biggen die een controle speenvoer, een vezelrijk speenvoer, een speenvoer met extra aminozuren of een vezelrijk speenvoer met extra aminozuren verstrekt kregen

\begin{tabular}{|c|c|c|c|c|c|c|}
\hline & $\begin{array}{l}\text { Controle } \\
\text { voer }\end{array}$ & $\begin{array}{l}\text { Vezelrijk } \\
\text { voer }\end{array}$ & $\begin{array}{l}\text { Voer met } \\
\text { extra } \\
\text { aminozuren }\end{array}$ & $\begin{array}{c}\text { Vezelrijk voer } \\
\text { met extra } \\
\text { aminozuren }\end{array}$ & SEM ${ }^{1}$ & P-waarde \\
\hline Aantal tomen & 15 & 15 & 14 & 15 & & \\
\hline Gem. pariteit & 4,6 & 4,7 & 4,1 & 4,1 & & \\
\hline Totaal geboren biggen & 15,5 & 15,4 & 14,5 & 13,9 & & 0,79 \\
\hline Levend geboren biggen & 14,8 & 14,3 & 14,1 & 13,1 & & 0,80 \\
\hline Doodgeboren biggen & 0,7 & 1,1 & 0,4 & 0,8 & & 0,91 \\
\hline $\begin{array}{l}\text { Geboortegewicht levend geboren } \\
\text { biggen }(\mathrm{kg})\end{array}$ & 1,38 & 1,38 & 1,33 & 1,32 & 0,064 & 0,89 \\
\hline Beginaantal biggen & 13,7 & 13,8 & 13,9 & 13,1 & & 0,26 \\
\hline $\begin{array}{l}\text { Geboortegewicht gespeende biggen } \\
(\mathrm{kg})\end{array}$ & 1,49 & 1,37 & 1,38 & 1,36 & 0,067 & 0,48 \\
\hline Aantal gespeende biggen & 11,9 & 12,1 & 12,2 & 11,5 & & 0,14 \\
\hline Speengewicht (kg) & 8,6 & 8,6 & 8,2 & 8,1 & 0,24 & 0,87 \\
\hline Lengte zoogperiode (d) & 27,7 & 27,6 & 26,7 & 26,3 & 0,46 & 0,92 \\
\hline Groei (g/d) & 254 & 260 & 253 & 254 & 7,0 & 0,74 \\
\hline \multicolumn{7}{|l|}{ Voeropname per big $(\mathrm{kg})$ : } \\
\hline - XL-korrel & 0,00 & 0,17 & 0,00 & 0,16 & 0,013 & 0,74 \\
\hline - creepfeed & 0,11 & 0,13 & 0,10 & 0,11 & 0,014 & 0,86 \\
\hline - speenvoer & 0,24 & 0,29 & 0,23 & 0,28 & 0,030 & 0,99 \\
\hline - totaal & 0,35 & 0,59 & 0,33 & 0,55 & 0,047 & 0,96 \\
\hline
\end{tabular}

${ }^{1}$ SEM $=$ gepoolde standard error van het gemiddelde 


\section{Bijlage 7 Technische resultaten gespeende biggen}

Technische resultaten van spenen tot vijf weken na spenen van biggen die vanaf circa 2,5 weken leeftijd controle voer, vezelrijk voer, voer met extra aminozuren of vezelrijk voer met extra aminozuren verstrekt kregen

\begin{tabular}{|c|c|c|c|c|c|c|}
\hline & $\begin{array}{c}\text { Controle } \\
\text { voer }\end{array}$ & $\begin{array}{c}\text { Vezelrijk } \\
\text { voer }\end{array}$ & $\begin{array}{c}\text { Voer met } \\
\text { extra } \\
\text { aminozuren }\end{array}$ & $\begin{array}{c}\text { Vezelrijk voer } \\
\text { met extra } \\
\text { aminozuren }\end{array}$ & SEM ${ }^{1}$ & P-waarde \\
\hline Aantal dieren & 144 & 132 & 144 & 144 & & \\
\hline Aantal dagen & 35 & 35 & 35 & 35 & & \\
\hline Groei (g/d) & 453 & 462 & 424 & 443 & 10,5 & 0,64 \\
\hline Voeropname $(\mathrm{kg} / \mathrm{d})$ & 0,60 & 0,62 & 0,58 & 0,59 & 0,015 & 0,58 \\
\hline Voederconversie & $1,31^{\mathrm{a}}$ & $1,34^{\mathrm{a}}$ & $1,38^{b}$ & $1,33^{a}$ & 0,014 & 0,01 \\
\hline
\end{tabular}

${ }^{1} \mathrm{SEM}=$ gepoolde standard error van het gemiddelde; ${ }^{2}$ Eén hok voortijdig uit het onderzoek genomen vanwege ernstig vechten;

$a, b$ Gemiddelden met een verschillende letter binnen een rij zijn verschillend $(p<0,05)$

Technische resultaten in de speenvoerfase en de opfokvoerfase van biggen die vanaf circa 2,5 weken leeftijd controle voer, vezelrijk voer, voer met extra aminozuren of vezelrijk voer met extra aminozuren verstrekt kregen

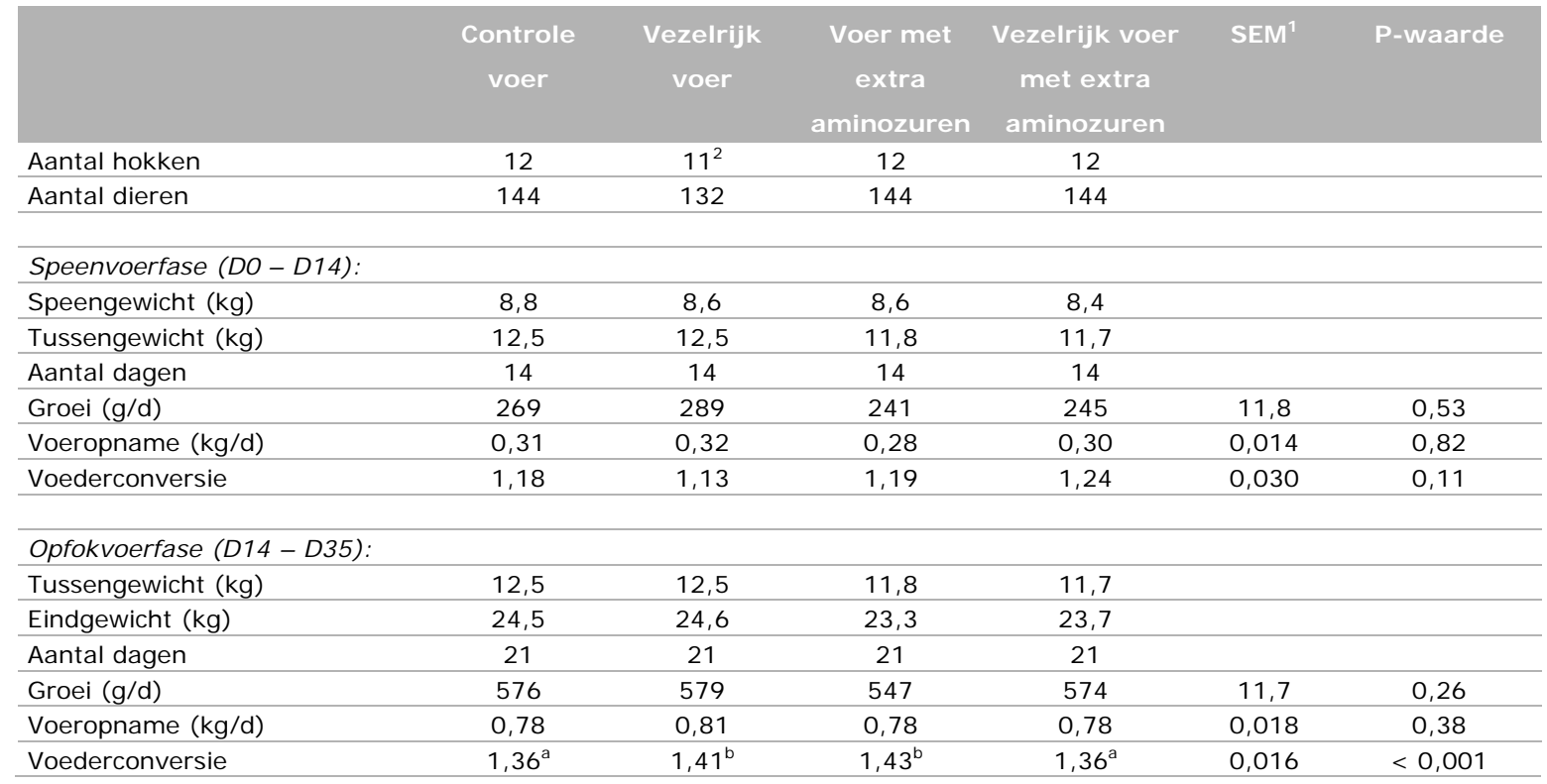

${ }^{1}$ SEM = gepoolde standard error van het gemiddelde; ${ }^{2}$ Eén hok voortijdig uit het onderzoek genomen vanwege ernstig vechten;

a,b Gemiddelden met een verschillende letter binnen een rij zijn verschillend $(p<0,05)$ 


\section{Bijlage 8 Technische resultaten vleesvarkens}

Technische resultaten van vleesvarkens die vanaf circa 2,5 weken leeftijd controle voer, vezelrijk voer, voer met extra aminozuren of vezelrijk voer met extra aminozuren verstrekt kregen

\begin{tabular}{|c|c|c|c|c|c|c|}
\hline & Controle voer & $\begin{array}{c}\text { Vezelrijk } \\
\text { voer }\end{array}$ & $\begin{array}{c}\text { Voer met } \\
\text { extra } \\
\text { aminozuren }\end{array}$ & $\begin{array}{c}\text { Vezelrijk voer } \\
\text { met extra } \\
\text { aminozuren }\end{array}$ & SEM ${ }^{1}$ & P-waarde \\
\hline Aantal hokken & 12 & 11 & 12 & 12 & & \\
\hline Aantal dieren & 135 & 121 & 136 & 140 & & \\
\hline \multicolumn{7}{|c|}{ Op basis van levend eindgewicht: } \\
\hline Opleggewicht (kg) & 24,4 & 24,6 & 23,2 & 23,8 & & \\
\hline Levend eindgewicht $(\mathrm{kg})$ & 123,1 & 122,0 & 121,8 & 120,0 & & \\
\hline Aantal dagen & 106,3 & 108,3 & 107,9 & 108,0 & & \\
\hline Groei $(g / d)$ & 936 & 912 & 923 & 902 & 11,6 & 0,85 \\
\hline Voeropname (kg/d) & 2,29 & 2,25 & 2,29 & 2,21 & 0,033 & 0,50 \\
\hline Voederconversie & $2,45^{x}$ & $2,47^{x y}$ & $2,48^{y}$ & $2,45^{x}$ & 0,018 & 0,10 \\
\hline \multicolumn{7}{|c|}{ Op basis van berekend eindgewicht: } \\
\hline Berekend eindgewicht $(\mathrm{kg})$ & 120,7 & 119,1 & 119,8 & 117,4 & & \\
\hline Groei (g/d) & 914 & 883 & 903 & 877 & 11,5 & 0,85 \\
\hline \multirow[t]{2}{*}{ Voederconversie } & 2,51 & 2,55 & 2,53 & 2,52 & 0,019 & 0,11 \\
\hline & $\begin{array}{c}\text { Controle } \\
\text { voer }\end{array}$ & $\begin{array}{c}\text { Vezelrijk } \\
\text { voer }\end{array}$ & $\begin{array}{c}\text { Voer met } \\
\text { extra } \\
\text { aminozuren }\end{array}$ & $\begin{array}{c}\text { Vezelrijk voer } \\
\text { met extra } \\
\text { aminozuren }\end{array}$ & SEM $^{1}$ & P-waarde \\
\hline Aantal hokken & 12 & 11 & 12 & 12 & & \\
\hline Aantal dieren & 135 & 121 & 136 & 140 & & \\
\hline \multicolumn{7}{|l|}{ Startvoerfase (D0 - D35): } \\
\hline Opleggewicht (kg) & 24,4 & 24,6 & 23,2 & 23,8 & & \\
\hline Tussengewicht $(\mathrm{kg})$ & 53,0 & 52,0 & 50,8 & 50,2 & & \\
\hline Aantal dagen & 35 & 35 & 35 & 35 & & \\
\hline Groei (g/d) & 818 & 783 & 790 & 756 & 13,5 & 0,96 \\
\hline Voeropname $(\mathrm{kg} / \mathrm{d})$ & 1,63 & 1,59 & 1,58 & 1,52 & 0,027 & 0,62 \\
\hline Voederconversie & 2,00 & 2,04 & 2,00 & 2,01 & 0,020 & 0,37 \\
\hline \multicolumn{7}{|l|}{ Tussenvoerfase (D35 - D63): } \\
\hline Tussengewicht (kg) & 53,0 & 52,0 & 50,8 & 50,2 & & \\
\hline Tussengewicht $(\mathrm{kg})$ & 79,1 & 77,9 & 76,8 & 75,9 & & \\
\hline Aantal dagen & 28 & 28 & 28 & 28 & & \\
\hline Groei (g/d) & 950 & 947 & 945 & 934 & 22,0 & 0,85 \\
\hline Voeropname $(\mathrm{kg} / \mathrm{d})$ & 2,28 & 2,28 & 2,32 & 2,20 & 0,047 & 0,21 \\
\hline Voederconversie & $2,40^{\mathrm{ab}}$ & $2,42^{\mathrm{ab}}$ & $2,46^{\mathrm{a}}$ & $2,36^{\mathrm{b}}$ & 0,030 & 0,05 \\
\hline \multicolumn{7}{|c|}{ Eindvoerfase op basis van levend eindgewicht (D63-afleveren): } \\
\hline Tussengewicht (kg) & 79,1 & 77,9 & 76,8 & 75,9 & & \\
\hline Levend eindgewicht $(\mathrm{kg})$ & 123,1 & 122,0 & 121,8 & 120,0 & & \\
\hline Aantal dagen & 43,3 & 45,3 & 44,9 & 45,0 & & \\
\hline Groei (g/d) & 1032 & 996 & 1019 & 1001 & 18,2 & 0,59 \\
\hline Voeropname $(\mathrm{kg} / \mathrm{d})$ & 2,86 & 2,79 & 2,85 & 2,79 & 0,051 & 0,95 \\
\hline Voederconversie & 2,78 & 2,80 & 2,80 & 2,78 & 0,040 & 0,57 \\
\hline \multicolumn{7}{|c|}{ Eindvoerfase op basis van berekend eindgewicht (D63-afleveren): } \\
\hline Berekend eindgewicht $(\mathrm{kg})$ & 120,7 & 119,1 & 119,8 & 117,4 & & \\
\hline Groei $(g / d)$ & 974 & 926 & 970 & 939 & 17,3 & 0,61 \\
\hline Voederconversie & 2,94 & 3,02 & 2,94 & 2,97 & 0,046 & 0,62 \\
\hline
\end{tabular}

${ }^{1}$ SEM = gepoolde standard error van het gemiddelde; ${ }^{a, b}$ Gemiddelden met een verschillende letter binnen een rij zijn verschillend $(p<0,05)$;

$x, y$ Gemiddelden met een verschillende letter binnen een rij tenderen naar verschillend $(p<0,10)$ 


\section{Bijlage 9 Slachtkwaliteit vleesvarkens}

Slachtkwaliteit van vleesvarkens die vanaf circa 2,5 weken leeftijd controle voer, vezelrijk voer, voer met extra aminozuren of vezelrijk voer met extra aminozuren verstrekt kregen

\begin{tabular}{|c|c|c|c|c|c|c|}
\hline & Controle voer & $\begin{array}{c}\text { Vezelrijk } \\
\text { voer }\end{array}$ & $\begin{array}{c}\text { Voer met } \\
\text { extra } \\
\text { aminozuren }\end{array}$ & $\begin{array}{c}\text { Vezelrijk voer } \\
\text { met extra } \\
\text { aminozuren }\end{array}$ & SEM ${ }^{1}$ & P-waarde \\
\hline Slachtgewicht (kg) & 95,2 & 93,6 & 94,4 & 92,5 & 0,91 & 0,85 \\
\hline Vleespercentage & 59,0 & 59,3 & 58,8 & 59,4 & 0,20 & 0,36 \\
\hline Aanhoudingspercentage & 77,7 & 77,3 & 77,9 & 77,4 & 0,24 & 0,81 \\
\hline
\end{tabular}

${ }^{1} \mathrm{SEM}=$ gepoolde standard error van het gemiddelde 


\section{Bijlage 10 Uitval biggen en vleesvarkens}

Aantal uitgevallen en veterinair behandelde zuigende biggen die een controle speenvoer, een vezelrijk speenvoer, een speenvoer met extra aminozuren of een vezelrijk speenvoer met extra aminozuren verstrekt kregen

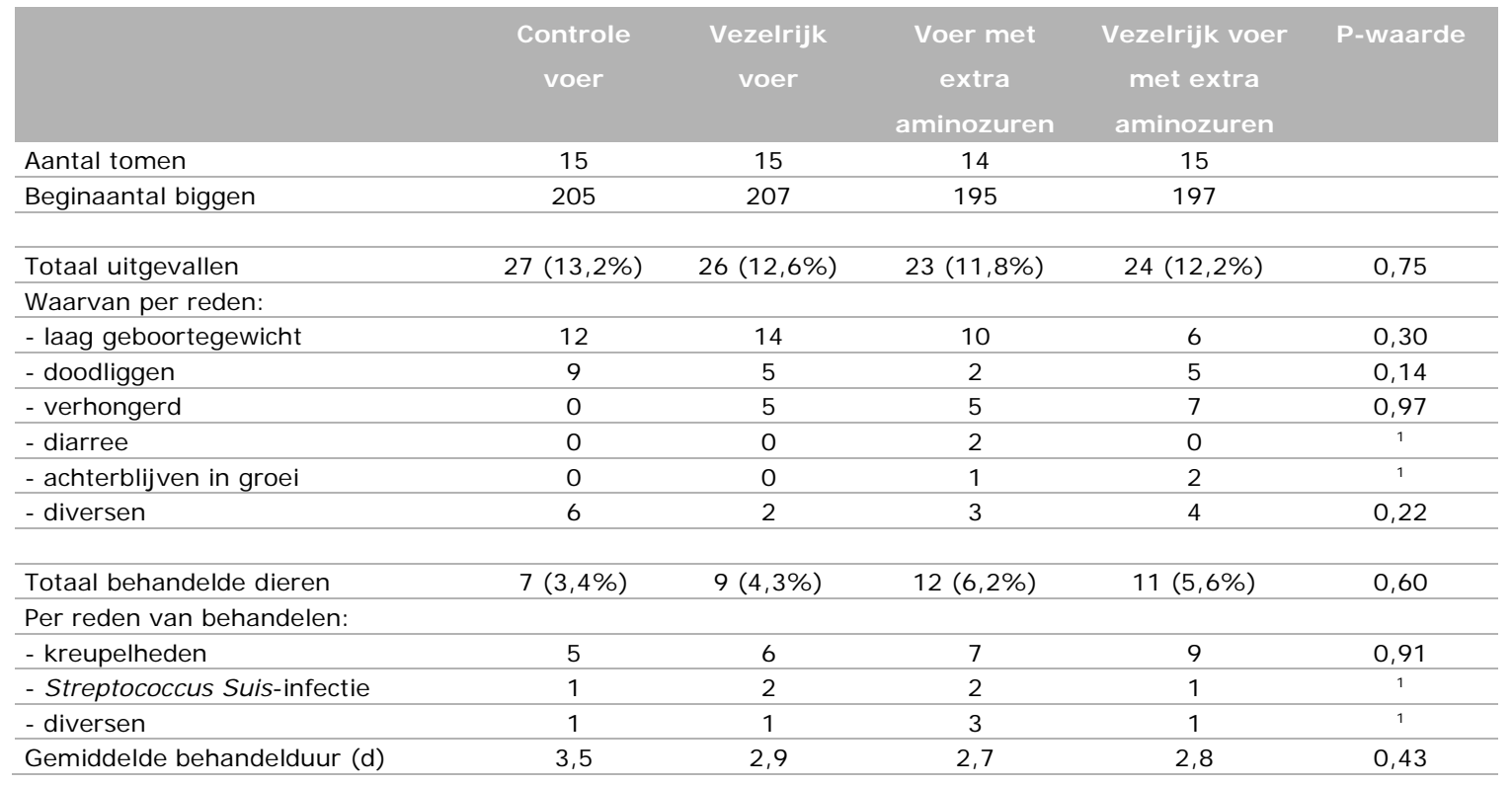

1 Aantallen te laag om te toetsen

Aantal uitgevallen en veterinair behandelde gespeende biggen die vanaf circa 2,5 weken leeftijd controle voer, vezelrijk voer, voer met extra aminozuren of vezelrijk voer met extra aminozuren verstrekt kregen

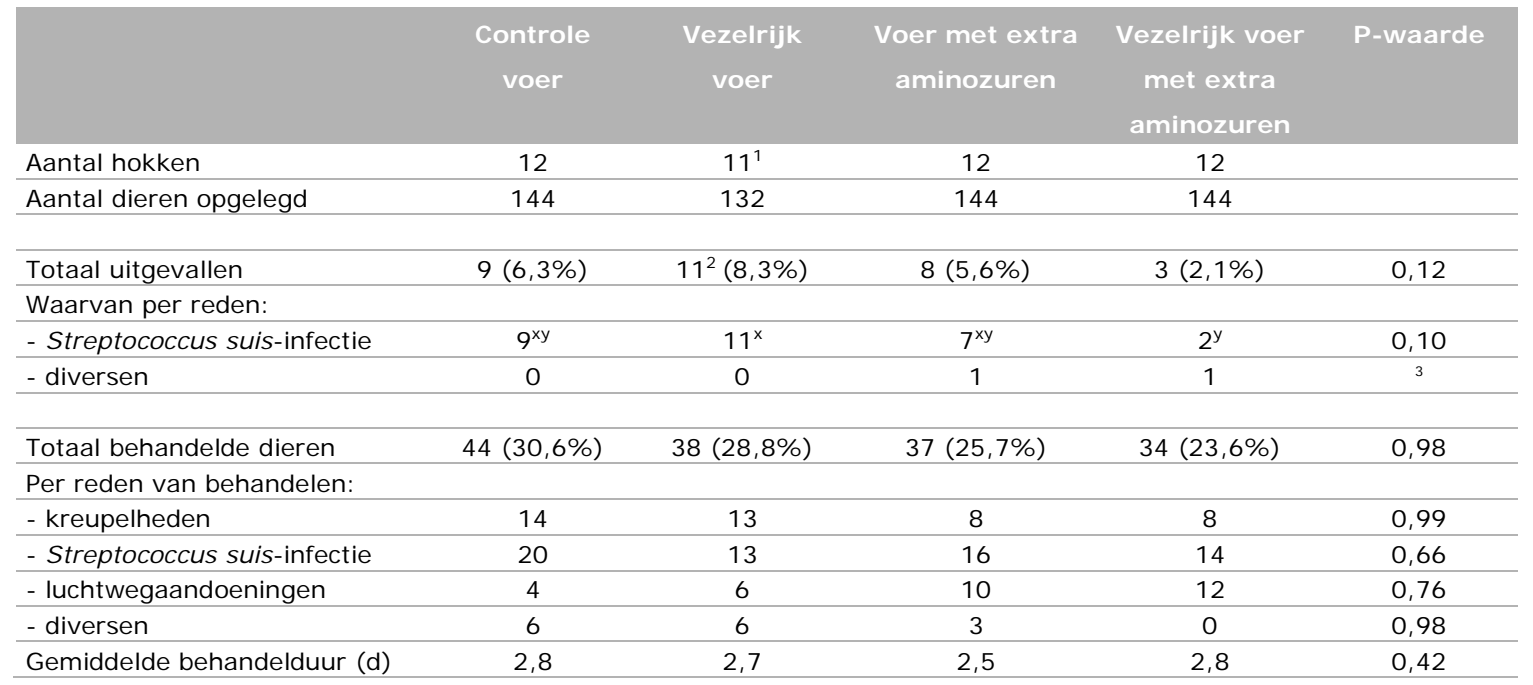

1 Eén hok voortijdig uit het onderzoek genomen vanwege vechten; ${ }^{2}$ Waarvan 5 dieren uit één hok; ${ }^{3}$ Aantallen te laag om te toetsen;

$x, y$ Gemiddelden met een verschillende letter binnen een rij tenderen naar verschillend $(p<0,10)$ 
Aantal uitgevallen en veterinair behandelde vleesvarkens die vanaf circa 2,5 weken leeftijd controle voer, vezelrijk voer, voer met extra aminozuren of vezelrijk voer met extra aminozuren verstrekt kregen

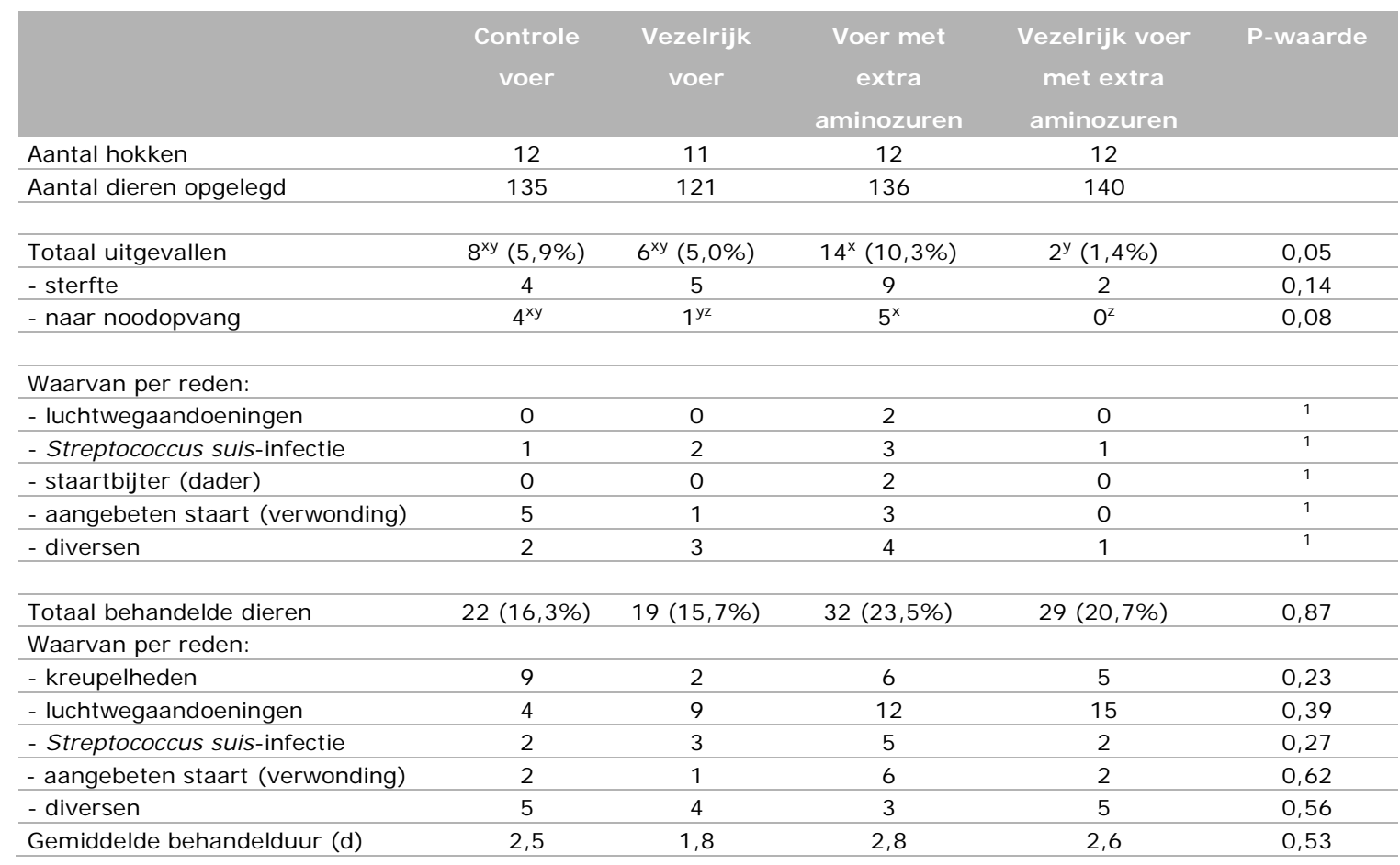

${ }^{1}$ Aantallen te laag om te toetsen; $x, y, z$ Gemiddelden met een verschillende letter binnen een rij tenderen naar verschillend $(p<0,10)$ 


\section{Bijlage 11 Staart-, oor- en flank- beschadigingen}

Percentage biggen met staart-, oor- en flankbeschadigingen op 4 weken leeftijd (bij spenen) die vanaf circa 2,5 weken leeftijd een controle speenvoer, een vezelrijk speenvoer, een speenvoer met extra aminozuren of een vezelrijk speenvoer met extra aminozuren verstrekt kregen

\begin{tabular}{|c|c|c|c|c|c|}
\hline & $\begin{array}{c}\text { Controle } \\
\text { voer }\end{array}$ & $\begin{array}{c}\text { Vezelrijk } \\
\text { voer }\end{array}$ & $\begin{array}{c}\text { Voer met } \\
\text { extra } \\
\text { aminozuren }\end{array}$ & $\begin{array}{c}\text { Vezelrijk voer } \\
\text { met extra } \\
\text { aminozuren }\end{array}$ & P-waarde \\
\hline Aantal tomen & 15 & 15 & 14 & 15 & \\
\hline Aantal biggen beoordeeld & 178 & 182 & 167 & 173 & \\
\hline \multicolumn{6}{|l|}{ Staartbeschadiging: } \\
\hline - geen beschadiging & 66,3 & 64,9 & 62,3 & 63,0 & 0,63 \\
\hline - bijtsporen & 25,8 & 19,2 & 28,1 & 23,7 & 0,69 \\
\hline - zichtbare wond & 7,9 & 15,9 & 9,6 & 13,3 & 0,36 \\
\hline \multicolumn{6}{|l|}{ Staartlengte intact: } \\
\hline - ja & 98,9 & 99,5 & 98,2 & 98,3 & 0,86 \\
\hline - nee, mist deel van de staart & 1,1 & 0,5 & 1,8 & 1,7 & 1 \\
\hline \multicolumn{6}{|c|}{ Oorbeschadiging één of beide oren: } \\
\hline - geen beschadiging & 84,8 & 86,8 & 86,8 & 91,3 & 0,40 \\
\hline \multicolumn{6}{|c|}{ Flankbeschadiging één of beide flanken: } \\
\hline - geen beschadiging & 100 & 99,5 & 100 & 100 & 0,99 \\
\hline
\end{tabular}

Percentage biggen met staart-, oor- en flankbeschadigingen op 9 weken leeftijd

\begin{tabular}{|c|c|c|c|c|c|}
\hline & $\begin{array}{c}\text { Controle } \\
\text { voer }\end{array}$ & $\begin{array}{c}\text { Vezelrijk } \\
\text { voer }\end{array}$ & $\begin{array}{c}\text { Voer met } \\
\text { extra } \\
\text { aminozuren }\end{array}$ & $\begin{array}{l}\text { Vezelrijk voer } \\
\text { met extra } \\
\text { aminozuren }\end{array}$ & P-waarde \\
\hline Aantal hokken & 12 & $11^{1}$ & 12 & 12 & \\
\hline Aantal dieren beoordeeld & 135 & 121 & 136 & 140 & \\
\hline \multicolumn{6}{|l|}{ Staartbeschadiging: } \\
\hline - geen beschadiging & 71,9 & 80,2 & 67,7 & 70,7 & 0,50 \\
\hline - bijtsporen & 11,8 & 7,4 & 14,7 & 11,4 & 0,68 \\
\hline - zichtbare wond & 16,3 & 12,4 & 17,6 & 17,9 & 0,67 \\
\hline \multicolumn{6}{|l|}{ Staartlengte intact: } \\
\hline - ja & $95,6^{\mathrm{ab}}$ & $99,2^{\mathrm{a}}$ & $97,1^{\mathrm{ab}}$ & $92,1^{\mathrm{b}}$ & 0,02 \\
\hline - nee, mist deel van de staart & $4,4^{\mathrm{ab}}$ & $0,8^{\mathrm{a}}$ & $2,9^{\mathrm{ab}}$ & $7,9^{\mathrm{b}}$ & 0,03 \\
\hline \multicolumn{6}{|c|}{ Oorbeschadiging één of beide oren: } \\
\hline - geen beschadiging & 79,2 & 81,8 & 82,4 & 87,9 & 0,61 \\
\hline \multicolumn{6}{|c|}{ Flankbeschadiging één of beide flanken: } \\
\hline - geen beschadiging & 100 & 100 & 99,3 & 100 & 0,99 \\
\hline
\end{tabular}


Percentage vleesvarkens met staart-, oor- en flankbeschadigingen op 14 weken leeftijd

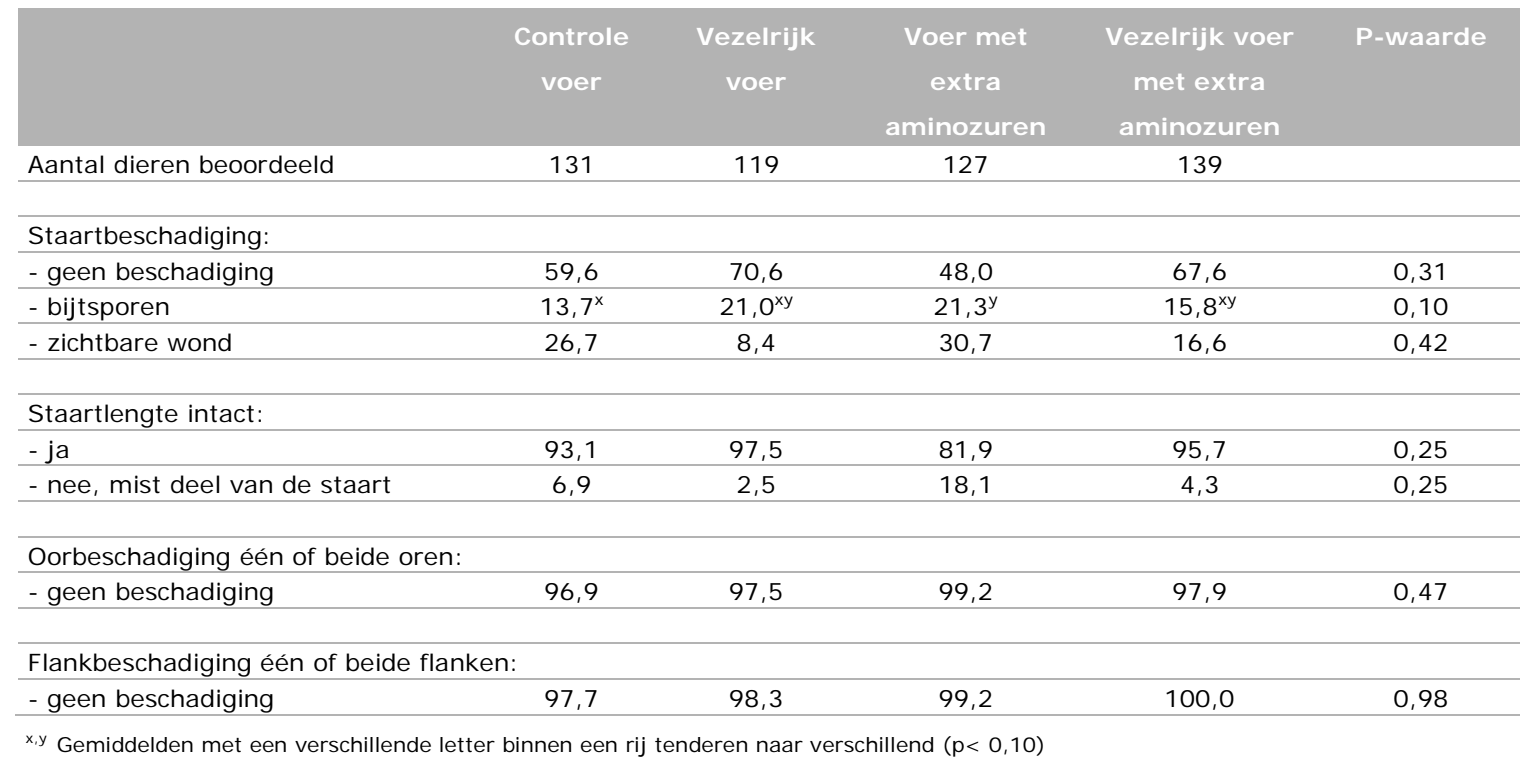

Percentage vleesvarkens met staart-, oor- en flankbeschadigingen op 18 weken leeftijd

\begin{tabular}{|c|c|c|c|c|c|}
\hline & $\begin{array}{c}\text { Controle } \\
\text { voer }\end{array}$ & $\begin{array}{c}\text { Vezelrijk } \\
\text { voer }\end{array}$ & $\begin{array}{c}\text { Voer met } \\
\text { extra } \\
\text { aminozuren }\end{array}$ & $\begin{array}{c}\text { Vezelrijk voer } \\
\text { met extra } \\
\text { aminozuren }\end{array}$ & P-waarde \\
\hline Aantal dieren beoordeeld & 127 & 118 & 125 & 138 & \\
\hline \multicolumn{6}{|l|}{ Staartbeschadiging: } \\
\hline - geen beschadiging & $45,7^{x}$ & $61,9^{y}$ & $63,2^{y}$ & $63,0^{y}$ & 0,072 \\
\hline - bijtsporen & 20,5 & 11,0 & 10,4 & 9,4 & 0,15 \\
\hline - zichtbare wond & 33,8 & 27,1 & 26,4 & 27,5 & 0,44 \\
\hline \multicolumn{6}{|l|}{ Staartlengte intact: } \\
\hline - ja & 80,3 & 86,4 & 69,6 & 82,6 & 0,37 \\
\hline - nee, mist deel van de staart & 19,7 & 13,6 & 30,4 & 17,4 & 0,37 \\
\hline \multicolumn{6}{|c|}{ Oorbeschadiging één of beide oren: } \\
\hline - geen beschadiging & 90,6 & 93,2 & 91,2 & 88,5 & 0,25 \\
\hline \multicolumn{6}{|c|}{ Flankbeschadiging één of beide flanken: } \\
\hline - geen beschadiging & $98,4^{x}$ & $96,6^{x y}$ & $95,2^{y}$ & $98,6^{x}$ & 0,086 \\
\hline
\end{tabular}

$x, y$ Gemiddelden met een verschillende letter binnen een rij tenderen naar verschillend $(p<0,10)$

Percentage vleesvarkens met staart-, oor- en flankbeschadigingen daags voor afleveren

\begin{tabular}{|c|c|c|c|c|c|}
\hline & $\begin{array}{c}\text { Controle } \\
\text { voer }\end{array}$ & $\begin{array}{c}\text { Vezelrijk } \\
\text { voer }\end{array}$ & $\begin{array}{c}\text { Voer met } \\
\text { extra } \\
\text { aminozuren }\end{array}$ & $\begin{array}{c}\text { Vezelrijk voer } \\
\text { met extra } \\
\text { aminozuren }\end{array}$ & P-waarde \\
\hline Aantal dieren beoordeeld & 126 & 116 & 122 & 138 & \\
\hline \multicolumn{6}{|l|}{ Staartbeschadiging: } \\
\hline - geen beschadiging $(1+2)$ & 75,4 & 75,0 & 88,5 & 82,6 & 0,32 \\
\hline - bijtsporen & 0,8 & 0,9 & 0,8 & 1,4 & 0,85 \\
\hline - zichtbare wond & 23,8 & 24,1 & 10,7 & 16,0 & 0,35 \\
\hline \multicolumn{6}{|l|}{ Staartlengte intact: } \\
\hline - ja & 77,8 & 83,6 & 63,9 & 81,2 & 0,17 \\
\hline - nee, mist deel van de staart & 22,2 & 16,4 & 36,1 & 18,8 & 0,17 \\
\hline \multicolumn{6}{|c|}{ Oorbeschadiging één of beide oren: } \\
\hline - geen beschadiging & 99,2 & 95,7 & 97,6 & 97,1 & 0,26 \\
\hline \multicolumn{6}{|c|}{ Flankbeschadiging één of beide flanken: } \\
\hline - geen beschadiging & 99,2 & 100 & 99,2 & 98,6 & 0,99 \\
\hline
\end{tabular}




\section{Bijlage 12 Gedragswaarnemingen}

Aantal keren bijten per hok gedurende 8 keer 10 minuten waarnemen bij biggen op 7 weken leeftijd die vanaf circa 2,5 weken leeftijd controle voer, vezelrijk voer, voer met extra aminozuren of vezelrijk voer met extra aminozuren verstrekt kregen

\begin{tabular}{|c|c|c|c|c|c|}
\hline & $\begin{array}{c}\text { Controle } \\
\text { voer }\end{array}$ & $\begin{array}{c}\text { Vezelrijk } \\
\text { voer }\end{array}$ & $\begin{array}{c}\text { Voer met } \\
\text { extra } \\
\text { aminozuren }\end{array}$ & $\begin{array}{c}\text { Vezelrijk voer } \\
\text { met extra } \\
\text { aminozuren }\end{array}$ & P-waarde \\
\hline Aantal hokken & 12 & 12 & 12 & 12 & \\
\hline Gemiddeld aantal dieren per hok & 11,6 & 11,6 & 11,7 & 11,9 & \\
\hline Staartbijten & 10,0 & 10,8 & 10,8 & 12,1 & 0,28 \\
\hline Oorbijten & 26,4 & 18,7 & 26,9 & 27,5 & 0,54 \\
\hline Anders bijten & $42,0^{a}$ & $22,5^{b}$ & $26,5^{b}$ & $32,3^{\mathrm{ab}}$ & 0,02 \\
\hline
\end{tabular}

${ }^{a, b}$ Gemiddelden met een verschillende letter binnen een rij zijn verschillend $(p<0,05)$

Aantal keren bijten per hok gedurende 8 keer 10 minuten waarnemen bij vleesvarkens op 21 weken leeftijd die vanaf circa 2,5 weken leeftijd controle voer, vezelrijk voer, voer met extra aminozuren of vezelrijk voer met extra aminozuren verstrekt kregen

\begin{tabular}{|c|c|c|c|c|c|}
\hline & $\begin{array}{c}\text { Controle } \\
\text { voer }\end{array}$ & $\begin{array}{c}\text { Vezelrijk } \\
\text { voer }\end{array}$ & $\begin{array}{c}\text { Voer met } \\
\text { extra } \\
\text { aminozuren }\end{array}$ & $\begin{array}{c}\text { Vezelrijk voer } \\
\text { met extra } \\
\text { aminozuren }\end{array}$ & P-waarde \\
\hline Aantal hokken & 12 & $11^{1}$ & 12 & 12 & \\
\hline Gemiddeld aantal dieren per hok & 10,6 & 10,6 & 10,3 & 11,5 & \\
\hline Staartbijten & 9,6 & 13,5 & 8,5 & 7,1 & 0,15 \\
\hline Oorbijten & 12,8 & 8,0 & 11,0 & 11,7 & 0,33 \\
\hline Anders bijten & $26,3^{a}$ & $14,1^{b}$ & $19,7^{\mathrm{ab}}$ & $23,0^{a}$ & 0,02 \\
\hline
\end{tabular}

1 Eén hok voortijdig uit het onderzoek genomen vanwege ernstig vechten; ${ }^{a, b}$ Gemiddelden met een verschillende letter binnen een rij zijn verschillend $(p<0,05)$ 



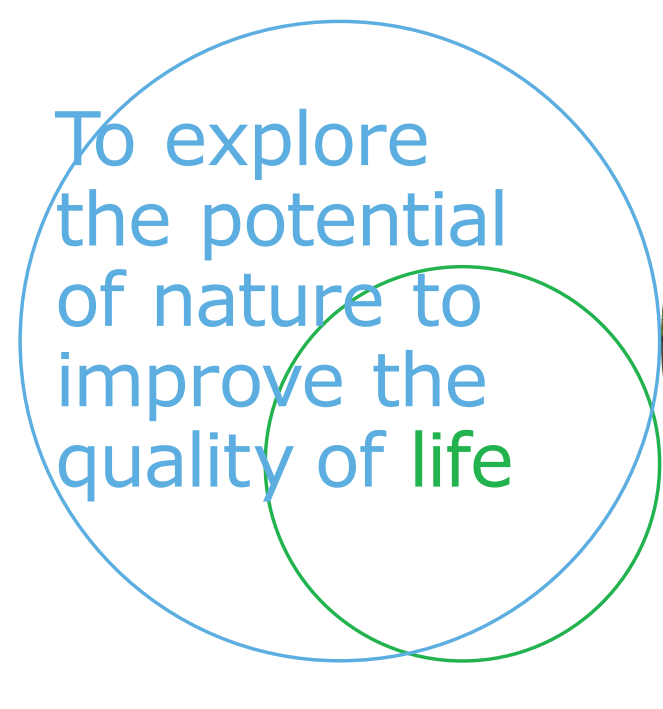

Wageningen Livestock Research Postbus 338

6700 AH Wageningen

T 0317483953

E info.livestockresearch@wur.nl www.wur.nl/livestock-research

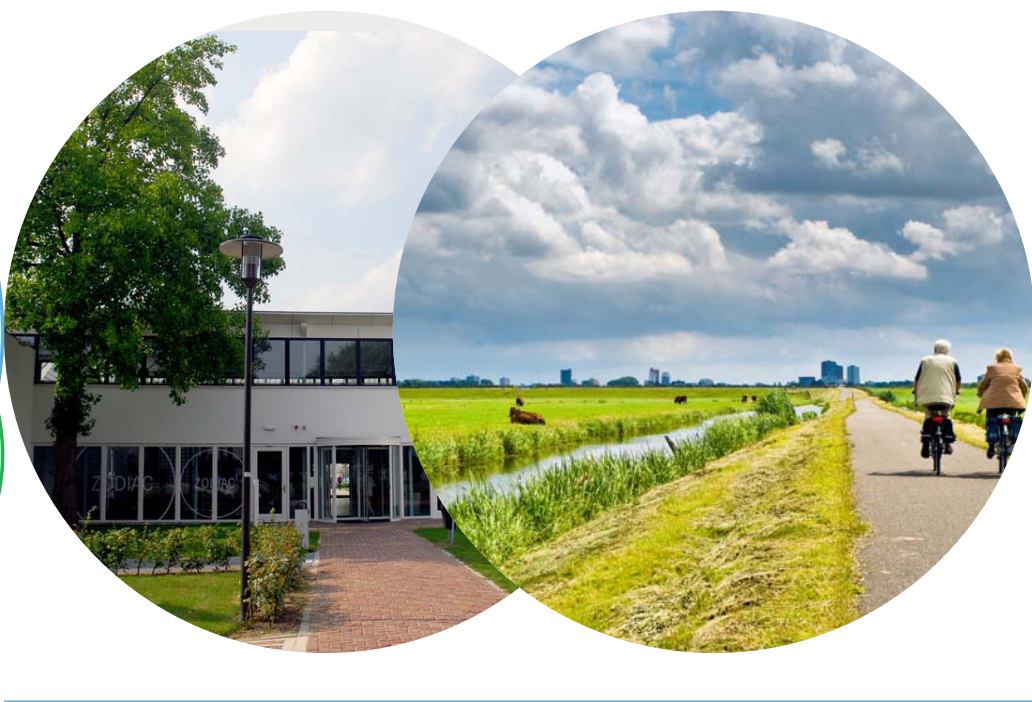

Wageningen Livestock Research ontwikkelt kennis voor een zorgvuldige en renderende veehouderij, vertaalt deze naar praktijkgerichte oplossingen en innovaties, en zorgt voor doorstroming van deze kennis. Onze wetenschappelijke kennis op het gebied van veehouderijsystemen en van voeding, genetica, welzijn en milieu-impact van landbouwhuisdieren integreren we, samen met onze klanten, tot veehouderijconcepten voor de 21 e eeuw.

De missie van Wageningen University \& Research is 'To explore the potential of nature to improve the quality of life'. Binnen Wageningen UR bundelen 9 gespecialiseerde onderzoeksinstituten van stichting DLO en Wageningen University hun krachten om bij te dragen aan de oplossing van belangrijke vragen in het domein van gezonde voeding en leefomgeving. Met ongeveer 30 vestigingen, 6.000 medewerkers en 10.000 studenten behoort Wageningen UR wereldwijd tot de aansprekende kennisinstellingen binnen haar domein. De integrale benadering van de vraagstukken en de samenwerking tussen verschillende disciplines vormen het hart van de unieke Wageningen aanpak. 